Prepared in cooperation with the U.S. Fish and Wildlife Service

\title{
Distribution and Movement of Bull Trout in the Upper Jarbidge River Watershed, Nevada
}

Open-File Report 2010-1033 



\section{Distribution and Movement of Bull Trout in the Upper Jarbidge River Watershed, Nevada}

By M. Brady Allen, Patrick J. Connolly, Matthew G. Mesa, Jodi Charrier, and Chris Dixon

Prepared in cooperation with the U.S. Fish and Wildlife Service

Open-File Report 2010-1033

U.S. Department of the Interior

U.S. Geological Survey 


\title{
U.S. Department of the Interior \\ KEN SALAZAR, Secretary
}

\section{U.S. Geological Survey \\ Marcia K. McNutt, Director}

U.S. Geological Survey, Reston, Virginia: 2010

\begin{abstract}
For more information on the USGS—-the Federal source for science about the Earth, its natural and living resources, natural hazards, and the environment, visit $h$ ttp://uww.usgs.gov or call 1-888-ASK-USGS.
\end{abstract}

For an overview of USGS information products, including maps, imagery, and publications, visit $h$ ttp://www.usgs.gov/pubprod

To order this and other USGS information products, visit http://store.usgs.gov

Suggested citation:

Allen, M.B., Connolly, P.J., Mesa, M.G., Charrier, Jodi, and Dixon, Chris, 2010, Distribution and movement of bull trout in the upper Jarbidge River watershed, Nevada: U.S. Geological Survey Open-File Report 2010-1033, 80 p.

Any use of trade, product, or firm names is for descriptive purposes only and does not imply endorsement by the U.S. Government.

Although this report is in the public domain, permission must be secured from the individual copyright owners to reproduce any copyrighted material contained within this report. 


\section{Contents}

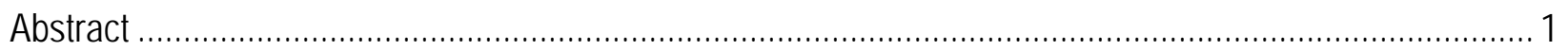

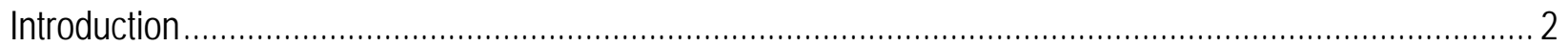

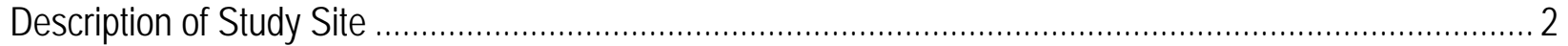

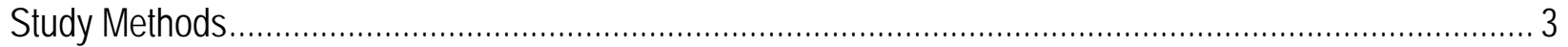

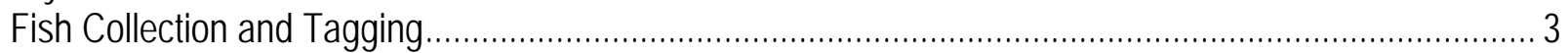

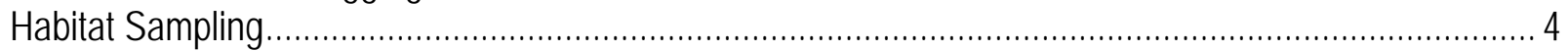

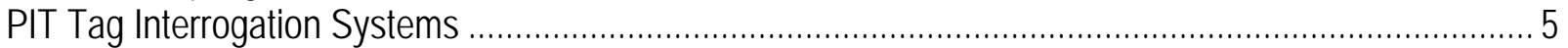

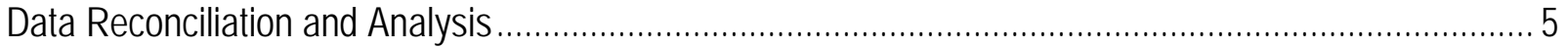

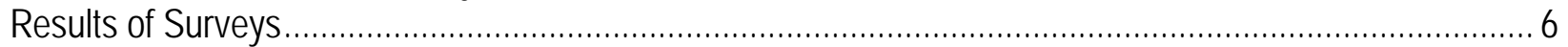

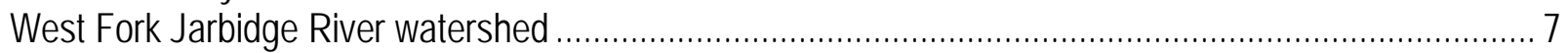

East Fork Jarbidge River Watershed ................................................................................... 9

Overall Distribution and Abundance of Bull Trout in Jack Creek.................................................... 12

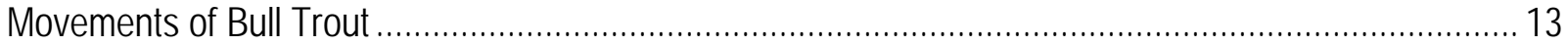

Distribution, Growth, and Movement of Bull Trout ..................................................................... 14

General Catch Information and Population Characteristics............................................................... 15

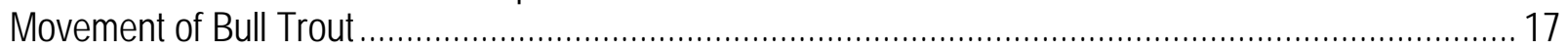

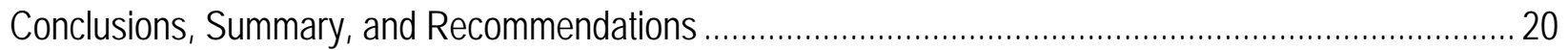

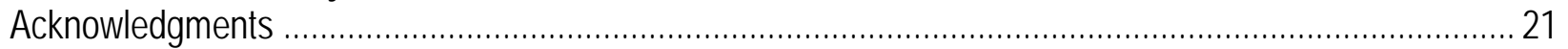

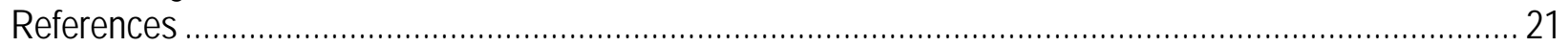

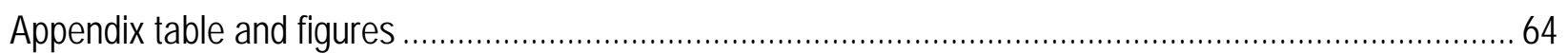

\section{Figures}

Figure 1. Map of the East and West Forks of the Jarbidge River, Idaho and Nevada, with the locations of reported fish barriers and passive integrated transponder (PIT) tag interrogations systems installed in 2006 or 2007.

Figure 2. Locations of fish and habitat surveys, fish barriers, and passive integrated transponder (PIT) tag interrogation systems in the West Fork Jarbidge River, Nevada, and its tributaries, 2006 and 2007

Figure 3. Locations of fish and habitat surveys, fish barriers, and passive integrated transponder (PIT) tag interrogation systems in the East Fork Jarbidge River, Nevada, and its tributaries, 2006 and 2007

Figure 4. Length frequency, in 2-mm increments, of all bull trout sampled in the West Fork Jarbidge River, Nevada, in 2006 and 2007.

Figure 5 . The number of bull trout (BLT) per meter by size class for all habitat units sampled along with altitude (upper graph) and the number of bull trout and redband trout (RBT) per meter by size class in pools only (lower graph) in West Fork Jarbidge River (rkm 21.5 - 30.2), Nevada, 2006 .... 29 Figure 6. Number of bull trout (BLT) per meter by size class for all habitat units sampled along with altitude (upper graph) and the number of bull trout and redband trout (RBT) per meter by size class in pools only (lower graph) in West Fork Jarbidge River (rkm 21.7 - 32.2), Nevada, 2007

Figure 7. Length frequency, in 2-mm increments, of all bull trout sampled in Pine Creek of the West Fork Jarbidge River subbasin, Nevada in 2006 and 2007

Figure 8. Number of bull trout (BLT) per meter by size class for all habitat units sampled along with altitude (upper graph) and the number of bull trout and redband trout (RBT) per meter by size class in pools only (lower graph) in Pine Creek (rkm 0 - 6.5), Nevada, 2006 
Figure 9. Number of bull trout (BLT) per meter by size class for all habitat units sampled along with altitude (upper graph) and the number of bull trout and redband trout (RBT) per meter by size class in pools only (lower graph) in Pine Creek (rkm 0 - 5.9), Nevada, $2007 . . .$. 33

Figure 10. Length frequency in 2-mm increments of all bull trout sampled in Jack Creek of the West Fork Jarbidge River, Nevada, in 2006 and 2007 34

Figure 11. Number of bull trout (BLT) per meter by size class for all habitat units sampled along with altitude (upper graph) and the number of bull trout and redband trout (RBT) per meter by size class in pools only (lower graph) in Jack Creek (rkm 0 - 4.3), Nevada, 2006 35

Figure 12. Number of bull trout (BLT) per meter, by size class, for all habitat units sampled along with altitude (upper graph) and the number of bull trout and redband trout (RBT) per meter by size class in pools only (lower graph) in Jack Creek (rkm 0 - 5.4), Nevada, 2007 36

Figure 13. Length frequency in 2-mm increments of all bull trout sampled in the East Fork Jarbidge River, Nevada, in 2006 and 2007. Sampling effort is not the same for each year...... 37

Figure 14. Number of bull trout (BLT) per meter by size class for all habitat units sampled along with altitude (upper graph) and the number of bull trout and redband trout (RBT) per meter by size class in pools only (lower graph) in East Fork Jarbidge River (rkm 15.6 - 24.7), Nevada, 2006

Figure 15. Number of bull trout (BLT) per meter by size class for all habitat units sampled along with altitude (upper graph) and the number of bull trout and redband trout (RBT) per meter by size class in pools only (lower graph) in East Fork Jarbidge River (rkm 32.5 - 35.0), Nevada, 2007 ..... 39 Figure 16. Length frequency in 2-mm increments of all bull trout sampled in Cougar Creek, Nevada, and an unnamed tributary of the East Fork Jarbidge River, Nevada, at rkm 33.5 (measured from the confluence with the West Fork Jarbidge River, Idaho), $2007 .$. 40

Figure 17. Number of bull trout (BLT) per meter by size class for all habitat units sampled along with altitude (upper graph) and the number of bull trout and redband trout (RBT) per meter by size class in pools only (lower graph) in Cougar Creek (rkm 0 - 3.1), Nevada, 2007.

Figure 18. Length frequency in 2-mm increments of all bull trout sampled in Fall Creek of the East Fork Jarbidge River, Nevada, in 2006 and 2007

Figure 19. Number of bull trout (BLT) per meter by size class for all habitat units sampled along with altitude (upper graph) and the number of bull trout and redband trout (RBT) per meter by size class in pools only (lower graph) in Fall Creek (rkm 0 - 2.0), Nevada, 2006 .....

Figure 20. Number of bull trout (BLT) per meter by size class for all habitat units sampled along with altitude (upper graph) and the number of bull trout and redband trout (RBT) per meter by size class in pools only (lower graph) in Fall Creek (rkm 1.4 - 3.2), Nevada, 2007.

Figure 21. Length frequency in 2-mm increments of all bull trout sampled in Slide Creek of the East Fork Jarbidge River, Nevada, in 2006 and 2007. Sampling effort is not the same for each year 45 Figure 22. Number of bull trout (BLT) per meter by size class for all habitat units sampled along with altitude (upper graph) and the number of bull trout and redband trout (RBT) per meter by size class in pools only (lower graph) in Slide Creek (rkm 0 - 5.5), Nevada, 2006.

Figure 23. Number of bull trout (BLT) per meter by size class for all habitat units sampled along with altitude (upper graph) and the number of bull trout and redband trout (RBT) per meter by size class in pools only (lower graph) in Slide Creek (rkm 4.6 - 7.7), Nevada, 2007.

Figure 24. Length frequency in 2-mm increments of all bull trout sampled in Dave Creek of the East Fork Jarbidge River, Nevada, in summer 2006, early summer 2007, and late summer 2007 48

Figure 25. Number of bull trout (BLT) per meter by size class for all habitat units sampled along with altitude (upper graph) and the number of bull trout and redband trout (RBT) per meter by size class in pools only (lower graph) in Dave Creek (rkm 6.8 - 11.7), Nevada, 2006 
Figure 26. Number of bull trout (BLT) per meter by size class for all habitat units sampled along with altitude (upper graph) and the number of bull trout and redband trout (RBT) per meter by size class in pools only (lower graph) in Dave Creek (rkm 6.8 - 14.0), Nevada, 2007. 50

Figure 27. Operational status of interrogation systems during 2007 in the Jarbidge River subbasin, Idaho and Nevada .51

Figure 28. Number and movement direction of PIT tagged bull trout by month detected at the interrogation site in the East Fork Jarbidge River (EFJ, rkm 4.1), Idaho, and at the East Fork Jarbidge River and West Fork Jarbidge River (Forks, rkm 0.1) interrogation sites, Idaho, during 2007 ...... 52 Figure 29. Streamflow (cfs), temperature, and direction of PIT tagged bull trout movements detected at interrogation sites in West Fork Jarbidge River ( $r k m$ 15), Jack Creek (rkm 0.1), and West Fork Jarbidge and Pine Creek confluence (rkm 26), Nevada, 2007 53

Figure 30. Time of day that PIT tagged bull trout passed any interrogation system in the Jarbidge River subbasin, Idaho and Nevada, in 2006 and 2007

\section{Tables}

Table 1. Number of bull trout the captured by electrofishing and PIT tagged in the East and West Forks of the Jarbidge River watershed in 2006 55

Table 2. Number of bull trout captured by electrofishing and PIT tagged in the West Fork Jarbidge River subbasin in 2007 .56

Table 3. Number of bull trout captured by electrofishing and PIT tagged in the East Fork Jarbidge River subbasin in 2007

Table 4. Location, altitude and estimated length of fish and habitat surveys conducted in the Jarbidge River watershed during 2006 58

Table 5. Location, altitude and estimated length of fish and habitat surveys conducted in the Jarbidge River watershed during 2007.

Table 6. Number (n) of bull trout captured, the sampling distance (rkm), the number of bull trout captured with a fork length greater than $200 \mathrm{~mm}$, the number of bull trout with a fork length greater than $250 \mathrm{~mm}$, the minimum (min) fork length, the maximum (max) fork length, and weight of bull trout for each creek sampled in the Jarbidge River watershed, Nevada, in 2006-2007

Table 7. Number ( $\mathrm{n}$ ) of bull trout (BLT) collected, survey length, percent of stream length with bull trout, the percent of habitat units with at least one bull trout, the percent of stream length that was pool-like, and percent of bull trout found in pools in the Jarbidge River watershed in 2006-2007.

Table 8. Location and installation date of passive integrated transponder (PIT) tag interrogation units installed in the Jarbidge River watershed in 2006-2007, and the number of bull trout (BLT) interrogated by tagging location in 2006-2007....

Table 9. Stream discharge in the Jarbidge River watershed on sampling dates in 2007 


\section{Conversion Factors and Datums}

\section{Conversion Factors}

\begin{tabular}{lll}
\hline \multicolumn{1}{r}{ Multiply } & \multicolumn{1}{c}{ By } & \multicolumn{1}{c}{ To obtain } \\
\hline centimeter $(\mathrm{cm})$ & 0.3937 & inch (in.) \\
millimeter (mm) & 0.03937 & inch (in.) \\
meter (m) & 3.281 & foot (ft) \\
kilometer (km) & 0.6214 & mile (mi) \\
square kilometer $\left(\mathrm{km}^{2}\right)$ & 0.3861 & square mile (mi $\left.{ }^{2}\right)$ \\
gram (g) & 0.03527 & ounce, avoirdupois (oz) \\
\hline
\end{tabular}

Temperature in degrees Celsius $\left({ }^{\circ} \mathrm{C}\right)$ may be converted to degrees Fahrenheit $\left({ }^{\circ} \mathrm{F}\right)$ as follows: ${ }^{\circ} \mathrm{F}=\left(1.8 \times{ }^{\circ} \mathrm{C}\right)+32$

Temperature in degrees Fahrenheit $\left({ }^{\circ} \mathrm{F}\right)$ may be converted to degrees Celsius $\left({ }^{\circ} \mathrm{C}\right)$ as follows: ${ }^{\circ} \mathrm{C}=\left({ }^{\circ} \mathrm{F}-32\right) / 1.8$

\section{Datums}

Horizontal coordinate information is referenced to the World Geodetic System of 1984 (WGS84) datum. Vertical coordinate information is referenced to the WGS84 EGM96 geoid.

Altitude, as used in this report, refers to distance above the vertical datum. 


\title{
Distribution and Movement of Bull Trout in the Upper Jarbidge River Watershed, Nevada
}

By M. Brady Allen, Patrick J. Connolly, Matthew G. Mesa, Jodi Charrier, and Chris Dixon

\begin{abstract}
In 2006 and 2007, we surveyed the occurrence of bull trout (Salvelinus confluentus), the relative distributions of bull trout and redband trout (Oncorhynchus mykiss), and stream habitat conditions in the East and West Forks of the Jarbidge River in northeastern Nevada and southern Idaho. We installed passive integrated transponder (PIT) tag interrogation systems at strategic locations within the watershed, and PIT-tagged bull trout were monitored to evaluate individual fish growth, movement, and the connectivity of bull trout between streams. Robust bull trout populations were found in the upper portions of the East Fork Jarbidge River, the West Fork Jarbidge River, and in the Pine, Jack, Dave, and Fall Creeks. Small numbers of bull trout also were found in Slide and Cougar Creeks. Bull trout were numerically dominant in the upper portions of the East Fork Jarbidge River, and in Fall, Dave, Jack, and Pine Creeks, whereas redband trout were numerically dominant throughout the rest of the watershed. The relative abundance of bull trout was notably higher at altitudes above 2,100 m.

This study was successful in documenting bull trout population connectivity within the West Fork Jarbidge River, particularly between West Fork Jarbidge River and Pine Creek. Downstream movement of bull trout to the confluence of the East Fork and West Fork Jarbidge River both from Jack Creek (rkm 16.6) in the West Fork Jarbidge River and from Dave Creek (rkm 7.5) in the East Fork Jarbidge River was detected. Although bull trout exhibited some downstream movement during the spring and summer, much of their emigration occurred in the autumn, concurrent with decreasing water temperatures and slightly increasing flows. The bull trout that emigrated were mostly age-2 or older, but some age- 1 fish also emigrated. Upstream movement by bull trout was detected less than downstream movement. The overall mean annual growth rate of bull trout in the East Fork and West Fork Jarbidge River was $36 \mathrm{~mm}$. This growth rate is within the range reported in other river systems and is indicative of good habitat conditions. Mark-recapture methods were used to estimate a population of 147 age-1 or older bull trout in the reach of Jack Creek upstream of Jenny Creek.
\end{abstract}




\section{Introduction}

The Jarbidge River population of bull trout (Salvelinus confluentus) was listed as threatened under the Endangered Species Act on April 8, 1999 (64 Federal Register 17110). Bull trout within the Jarbidge River are presumably limited to a single core area within the upper watershed, which comprises six local populations: (1) East Fork Jarbidge River (including the East Fork headwaters, Cougar Creek, and Fall Creek); (2) West Fork Jarbidge River (including Sawmill Creek); (3) Dave Creek; (4) Jack Creek; (5) Pine Creek; and (6) Slide Creek (U.S. Fish and Wildlife Service, 2004). Bull trout populations in these areas are thought to be mostly local, with few migratory (fluvial) fish present. In 2004, the Jarbidge River Bull Trout Recovery Team estimated that fewer than 500 bull trout, with 50-125 reproductively mature fish, were present within the core area (U.S. Fish and Wildlife Service, 2004). Several factors are suspected to have limited the Jarbidge River bull trout population historically, including livestock grazing, elevated water temperatures, road construction and maintenance, mining, and hatchery supplementation of rainbow trout (Oncorhynchus mykiss) (U.S. Fish and Wildlife Service, 2004). Stocking of hatchery rainbow trout was suspended in 1998.

In 2006, the U.S. Fish and Wildlife Service (USFWS) formed a cooperative agreement with the U.S. Geological Survey’s (USGS) Columbia River Research Laboratory (CRRL) for USGS to collect information on the life history, movements, abundance, and distribution of bull trout in the upper Jarbidge River basin. This information was needed to assist managers in making informed decisions regarding bull trout recovery. The objectives of the resulting study were to: (1) monitor the movements, distribution, and growth of bull trout in selected tributaries of the Jarbidge River basin; (2) estimate the abundance of selected local bull trout populations; (3) conduct habitat surveys and assess habitat conditions; and (4) use the data collected as a baseline to develop a cost-effective monitoring strategy to assess population trends over time until recovery is achieved. The USGS investigators regularly coordinated with the Jarbidge River Bull Trout Recovery Team, which comprises staff members from the Idaho Department of Environmental Quality, Bureau of Land Management (BLM), Nevada Department of Wildlife (NDOW), the U.S. Forest Service (USFS), USFWS, and Idaho Department of Fish and Game. This report summarizes study findings from 2006 and 2007.

\section{Description of Study Site}

The headwaters of the Jarbidge River are in the Jarbidge Mountains of northeastern Nevada. The watershed is characterized by an elevated volcanic plateau that gradually slopes northward to the Snake River Plain, which drains approximately 1,264 km² (488 $\mathrm{mi}^{2}$; U.S. Fish

and Wildlife Service, 2004). The upper watershed has a mountainous north-south crest with eight peaks greater than 3,050 m (10,000 ft) high. The East Fork and West Fork of the Jarbidge River flow northward for about 36 and $32 \mathrm{~km}$, respectively, and merge about $6.4 \mathrm{~km}$ downstream of the Idaho-Nevada border. This confluence of the two forks was the downstream extent of our study area (fig. 1). The mainstem Jarbidge River continues another $45 \mathrm{~km}$ northwest and eventually empties into the Bruneau River in Idaho. Riparian vegetation in the watershed consists of juniper (Juniperus spp.), black cottonwood (Populus balsamifera), subalpine fir (Abies lasiocarpa), aspen (Populus tremuloides), and various forbs, grasses, and sedges (U.S. Fish and Wildlife Service, 2004). The Jarbidge Mountains have a subalpine climate and receive substantial amounts of precipitation, primarily in the form of snow, which is the major source of 
water for streams in the basin. Additional precipitation falls as rain during thunderstorms. Runoff follows the natural hydrograph, with high spring and early summer flows that diminish in the late summer but increase slightly during fall and winter. The only streamgaging station in the watershed is within our study area on the West Fork Jarbidge River downstream of Jarbidge, Nevada (USGS station number 13162225).

\section{Study Methods}

\section{Fish Collection and Tagging}

We sampled all streams within the Jarbidge River basin known to contain bull trout as identified by the Jarbidge River Bull Trout Recovery Team. These included parts of the East Fork and West Fork Jarbidge River, and Cougar, Fall, Slide, Dave, Jack, and Pine Creeks (figs. 2 and 3; tables 1, 2, and 3). In an attempt to find other streams containing bull trout, we conducted exploratory sampling in selected reaches of Deer, Buck, Sawmill, and God's Pocket Creeks, and on an unnamed tributary of the East Fork Jarbidge River. Successive samples were collected in an upstream direction with the goal of reaching the end of fish distribution while tagging as many bull trout as possible of the appropriate size. In several streams, some sections were skipped in an effort to sample reaches with higher bull trout densities, which maximized the returns of the effort given the time allotted. The upper end of fish distribution was confirmed by electrofishing upstream of the likely barrier for approximately $100 \mathrm{~m}$ where practicable.

Bull trout samples were collected using a Smith-Root model 15-B backpack electrofisher equipped with one small probe and one "rat tail" electrode. Each stream reach was electrofished in a single upstream pass and all habitats likely to contain bull trout were sampled. All observed bull trout were captured. Redband trout were not captured, but were enumerated and generally classified as being less than $80 \mathrm{~mm}, 80$ to $150 \mathrm{~mm}$, or larger than $150 \mathrm{~mm}$ in pools only. The occurrence of redband trout in pools was recorded to indicate their general abundance without overly slowing the progress of the sampling crew that would have resulted if redband trout had been counted and classified in the much longer non-pool sections as well. The general abundance of other fish species was noted as rare, present, or highly abundant. All captured bull trout were anesthetized with a 50-mg/L solution of tricaine methanesulfonate (MS-222), measured fork length to the nearest millimeter, weighed to the nearest $0.1 \mathrm{~g}$, and inspected for reproductive status and external signs of disease or injury.

We tagged bull trout using full-duplex SGL model passive integrated transponder (PIT) tags (manufactured by Biomark, Inc., Boise, Idaho) that were $12 \mathrm{~mm}$ in length and operated at a frequency of $134.2 \mathrm{kHz}$. Fish less than $70 \mathrm{~mm}$ were considered too small to tag. In fish between 70 and $120 \mathrm{~mm}$ long, tags were injected into the peritoneal cavity. Fish greater than $120 \mathrm{~mm}$ were tagged in the dorsal sinus to minimize the potential for shedding of tags during spawning. A sample of caudal fin tissue was removed from most bull trout, placed in a pre-labeled vial containing $2 \mathrm{~mL}$ of $100 \%$ non-denatured ethanol, and sent to the USFWS's Abernathy Fish Technology Center (Longview, Wash.) for genetic analysis as part of a separate, but coordinated study (De Haan and others, 2007). Where bull trout were locally abundant, a genetic sample was taken from a subset of bull trout; otherwise a genetic sample was collected from each fish. After they recovered from the effects of tagging, fish were released in the location of capture. 
In 2007, we conducted a Petersen mark-recapture population estimate for bull trout in Jack Creek. To facilitate repeatability, Jack Creek was selected because of ease of access and the known presence of a bull trout population. The population was estimated in two sections of Jack Creek: from the confluence with West Fork Jarbidge River upstream to the confluence of Jenny Creek (rkm 1.8); and upstream of Jenny Creek to the end of fish distribution (rkm 5.4). Three block nets and a picket weir were placed consecutively at the downstream end of each section to ensure a closed population. We electrofished the sections in one slow, methodical upstream pass, each within 1 day. In both the $3.6 \mathrm{~km}$ section upstream of Jenny Creek and the $1.8 \mathrm{~km}$ section downstream, three people started at the block nets on the downstream end, and three others started at the mid point. Only bull trout longer than $80 \mathrm{~mm}$ (age-1 or older) were included in the estimate. We tagged all captured bull trout, and the recapture effort occurred 24-30 h later.

\section{Habitat Sampling}

Along with electrofishing, we conducted habitat surveys using the classification system described by Bisson and others (2006), which is a modification of an earlier hierarchical subdivision of channel units by Hawkins and others (1993). Using this system, we classified habitat units into pools and non-pools. We conducted daily visual distance calibrations for personnel with a measuring tape. On the basis of these visual estimates, we recorded the length and width of each habitat unit. We also measured maximum and mean water depths, and visually estimated the percent total instream and overhead cover by cover type (for example, large and small wood, substrate, and undercut bank), and percent riparian shade provided by trees and shrubs. Global positioning system (GPS) location coordinates and altitudes were recorded at the beginning and end of the survey each day. Stream temperature data were collected with a handheld thermometer at all electrofishing sites — in the morning, at mid-day, and in the afternoon (appendix table A1) - to ensure that temperatures were appropriate for electrofishing or PIT tagging. Because of the high variability of water temperatures measured with handheld thermometers, owing to the time of year, time of day, weather, and proximity to springs, among other factors, this temperature information was not used in the analysis, but is provided in the appendix. Stream temperatures also were recorded by the BLM via a network of automated thermographs placed at various sites throughout the East and West Forks Jarbidge Rivers; this temperature information was used in the analysis.

Seven streamflow monitoring stations were established near the PIT tag interrogation system (PTIS) sites for the purposes of this study. Stream discharge measurements were made at each of these stations three times in August 2007 to assess tributary contributions to overall flow. Following the protocol of Bain and Stevenson (1999), we anchored a measuring tape perpendicular to streamflow and recorded the distance to the left and right wetted edge. We measured water depth and velocity with a Marsh-McBirney model 2000 flow meter at a minimum of 10 (although usually at about 20) intervals along the measuring tape. Because water depths were always less than $1 \mathrm{~m}$, water velocities were measured at $60 \%$ of the depth at each interval. 


\section{PIT Tag Interrogation Systems}

On September 15, 2006, we installed instream PTISs at three locations: at the mouth of Jack Creek; in West Fork Jarbidge River about 2.4 km downstream of Jack Creek; and in East Fork Jarbidge River near the town of Murphy Hot Springs, Idaho (fig. 1). At Jack Creek, one PIT tag transceiver (model FS2001F-ISO, Digital Angel, St. Paul, MN, USA) with a single custom antenna was installed. This site was powered by one 12-volt battery, which was trickle-charged by a solar panel. On the West Fork Jarbidge River, we installed two stream-width, pass-by antennas connected to a multiplexing transceiver (model FS1001M (MUX), Digital Angel, St. Paul, Minn., USA). The transceiver was powered by four 12-volt batteries, which were tricklecharged by two solar panels. The design of the PTIS in the East Fork Jarbidge River was similar to that in the West Fork Jarbidge River, but with two arrays of two pass-through antennas installed. The multiple-antenna design system, which was used and is described by Connolly and others (2005), was expected to provide high detection efficiencies; however, the systems installed for this project had two arrays instead of three, which would reduce the detection efficiencies as well as the ability to calculate them (Connolly and others, 2008). Data from the PTISs were downloaded and the batteries were changed once a week from September through December 2006, after which the equipment was removed for the winter.

In 2007, six PTISs were installed, three at the pre-established (in 2006) sites and three at new sites. On April 28, 2007, the three PTISs described above were reinstalled (fig. 1). In Dave Creek, on May 23, 2007, at about rkm 0.4, a single-antenna PTIS was installed similar to the one in Jack Creek. In the West Fork Jarbidge River, a MUX-style PTIS was installed on July 16, 2007, at the confluence of Pine Creek (rkm 26.2), with two stream-width antennas in Pine Creek and two in the West Fork Jarbidge River just downstream of the confluence. At the confluence of the East Fork and West Fork Jarbidge River ("the Forks"), another PTIS was installed on July 17, 2007. This system was comprised of two stream-width antennas in both the East Fork and West Fork Jarbidge River. To prevent damage to the PTIS equipment during winter, the units were removed from all sites on December 19, 2007. In general, the PTISs were strategically placed to investigate the potential linkage between local populations of fish throughout the watershed. In both years, the systems were tested with a test tag when battery exchanges or data downloading occurred.

\section{Data Reconciliation and Analysis}

Detections of PIT tagged fish were merged with tagging data. We used independent reconciliation of PIT tag records by two biologists to classify movements as upstream, downstream, or of unknown direction. The time and location of tagging and other interrogation events were used to determine the direction of fish movements. If multiple interrogation events of the same fish occurred within 2 days, they were considered to be one movement event. Directional fish movement events were accepted when there was consensus on the direction of movement by the two biologists. If discrepancies in assigning direction could not be reconciled, the movement was recorded as an unknown direction. The operational run times for the systems were determined using the buffer data (see below) and the field log notebooks of the PTIS units. The buffer data provided records of the dates and times that each interrogation system was running. Additional information was obtained by reviewing the field notes, which were recorded during downloading. 
Recaptured bull trout were used to calculate information on movement and growth rates. Annual growth rates were calculated for all recaptured fish with more than 320 days between tagging and recapture. Because the number of days between tagging and recapture varied among individuals and between fish in different streams, the annual growth rate was standardized to a full year by dividing the change in length by the fraction of the year between capture and recapture. We conducted length frequency analysis to determine fish age at length for age-0 to age-2 bull trout. The length frequency histograms exhibit distinct modes of the first few age classes, which can provide insight into annual growth rates. The growth rate from length frequency analysis was validated with growth rates calculated via recaptured PIT tagged fish.

For our mark recapture study, we estimated the number of bull trout in two sections of Jack Creek as follows:

$$
N=[(M+1) *(\mathrm{C}+1) / R+1]-1,
$$

where $M=$ number of fish marked on the first sample, $C=$ number of fish captured in the second sample, and $R=$ number of fish with a mark captured in the second sample. The confidence interval for each estimate was calculated using a binomial distribution when $R / C$ was greater than 0.10 (Seber, 1982).

To estimate discharge at our streamflow monitoring stations, flow was computed by summing the flows of intervals, where the flow at each interval was calculated using the equation:

$$
Q_{n}=d_{n} \times\left(\frac{b_{n+1}-b_{n-1}}{2}\right) \times v_{n},
$$

where $Q_{n}=$ discharge at interval $n, d_{n}=$ water depth at interval $n, b_{n}=$ distance along the tape measure from the left wetted edge to point $n$, and $v_{n}=$ mean velocity in interval $n$.

\section{Results of Surveys}

From July 19 to October 4, 2006, we sampled a total of $39.9 \mathrm{~km}$ of stream channel in reaches of East Fork and West Fork Jarbidge River, and in Fall, Slide, Dave, Jack, and Pine Creeks (figs. 2 and 3). A total of 349 bull trout were captured, of which 322 were PIT tagged and 237 were fin clipped for genetic analysis by the USFWS (table 1). The majority (84\%) of fish were PIT tagged in Dave Creek, West Fork Jarbidge River, and Jack Creek. We collected only a few age-0 bull trout - three in upper Jack Creek, two in upper West Fork Jarbidge River, and one in Pine Creek. Sampling ended because of observed spawning activity by fish in Dave (August 6), Slide (August 22), and Jack (September 11) Creeks. We observed no direct bull trout mortalities during sampling in 2006.

From June 13 to September 14, 2007, we sampled $24.9 \mathrm{~km}$ of stream channel in the West Fork Jarbidge River and its tributaries, and $18 \mathrm{~km}$ of stream channel in the East Fork Jarbidge River and its tributaries (tables 2 and 3). The total lengths of stream sampled and latitude and longitude of the start and end points are shown in tables 4 and 5. In 2007, 1,353 bull trout were captured, of which 1,214 were PIT tagged, and 569 were fin clipped for genetic analysis (tables 2 and 3). The majority (88\%) of bull trout were PIT tagged in upper East Fork Jarbidge River, upper West Fork Jarbidge River, and Dave, Pine, and Jack Creeks. We collected substantially more age-0 fish in 2007 than in 2006 - four fish in upper Dave Creek, 41 fish in Jack Creek, 
36 fish in Pine Creek, and a single 28-mm bull trout collected on June 22, 2007, in the upper West Fork Jarbidge River. Three fish died as a consequence of electrofishing (direct mortality) in 2007, which was $0.2 \%$ of the total number of bull trout handled.

In addition to bull trout, redband trout, sculpin (Cottus spp.), and mountain whitefish (Prosopium williamsoni) were commonly encountered during sampling. In 2006, in the lower East Fork Jarbidge River just upstream of Murphy Hot Springs, we also encountered dace (Rhinichthys spp.), bridgelip sucker (Catostomus columbianus), and redside shiner (Richardsonius balteatus). We found no evidence of disease or introgression (vermiculation and pigment on the dorsal fin) with brook trout (Salvelinus fontinalis) in any of the bull trout we captured.

\section{West Fork Jarbidge River watershed}

West Fork Jarbidge River.- In 2006, one bull trout was captured near the West Fork Jarbidge River antenna site (rkm 14.5-15.5), and 96 fish were captured between rkm 22.0-30.0 (table 1). Sampling was stopped $1.3 \mathrm{~km}$ downstream of the end of fish distribution (as determined in 2007) due to time constraints. In 2007, sampling started at the first bridge upstream of the town of Jarbidge (rkm 21.7) and ended at rkm 32.2, $100 \mathrm{~m}$ upstream of a 1.3-m barrier falls, which was the uppermost point of fish distribution, as indicated by our sampling. We also sampled about a 100-m long reach of Sawmill Creek (which contributed 25\% of the total West Fork Jarbidge River flow) and captured one redband trout and no bull trout. Several temporary, naturally formed low-flow fish barriers (substrate and wood) were present in West Fork Jarbidge River in 2007, with the most downstream barrier about $1.5 \mathrm{~km}$ upstream of the confluence with Pine Creek. In 2007, 272 bull trout were captured between rkm 21.7 and 32.2 (table 2, fig. 2). For both years, the minimum fork length was $23 \mathrm{~mm}$, and the maximum was 330 $\mathrm{mm}$ (table 6). Most of the bull trout were age-1 and age-2, with relatively few fish longer than $200 \mathrm{~mm}$ (11\% of our catch in 2006, 7\% in 2007; table 6, fig. 4).

In 2007, we recaptured six bull trout that were originally PIT tagged in July and August 2006. The mean annual growth rate of these fish was $32 \mathrm{~mm}$ (range $=8-39 \mathrm{~mm}$; $\mathrm{SD}=4.8$; fig. 4). The length of these fish at tagging ranged from 90 to $185 \mathrm{~mm}$. Using length-frequency analysis, we estimated age- 1 bull trout to be between 83 and $115 \mathrm{~mm}$ and age-2 fish to be longer than $120 \mathrm{~mm}$ in late July and early August 2006. In June 2007, age-1 bull trout were between 70 and $115 \mathrm{~mm}$, and age-2 fish were from 120 to about $160 \mathrm{~mm}$.

In both years, bull trout were found primarily at altitudes above 2,100 $\mathrm{m}$ and in greater abundance at increasingly greater altitudes (figs. 5 and 6). Redband trout were found throughout the area we sampled, but with reduced abundances as altitude increased. In 2006, bull trout longer than $200 \mathrm{~mm}$ were more common in the lower altitude reaches than in the higher reaches, but they were more evenly distributed in 2007. We sampled earlier in 2007 (June-July) than in 2006 (July-September), which could account for the differences in fish distribution. We sampled earlier in the year in 2007 because we encountered spawning activity during our sampling in 2006. A single age- 0 bull trout was collected in the West Fork Jarbidge River in each year (figs. 4,5 , and 6). These fish were collected in the uppermost reaches, at altitudes greater than 2,100 $\mathrm{m}$ (figs. 5 and 6). 
Of the $12,586 \mathrm{~m}$ of stream channel surveyed in 2006, $21 \%$ of the habitat units contained at least one bull trout. In 2006, 20\% of the bull trout were found in pools and $16 \%$ of the habitat length we surveyed was pool habitat (table 7). In 2007, 50\% of the habitat units surveyed contained at least one bull trout. Fifteen percent of these fish were found in pools and $12 \%$ of the habitat length we surveyed was pool habitat (table 7). In 2007, the upper end of our sampling was located higher in the basin (fig. 2), which may account for the greater number of habitat units containing bull trout.

Pine Creek.-Sampling in Pine Creek in both years began at the confluence of Pine Creek and West Fork Jarbidge River (fig. 2). In July 2006, about 5.5 km of stream habitat were sampled, with the exception of about $1.8 \mathrm{~km}$ of middle Pine Creek. In August 2007, sampling was continuous over $5.9 \mathrm{~km}$ of stream, but stopped about $200 \mathrm{~m}$ downstream of the end of fish distribution (as assessed by visual survey). In 2006, 27 bull trout were captured and 25 were PIT tagged (table 1). In 2007, 430 bull trout were captured, of which 380 were PIT tagged (table 2). Fish lengths ranged from 39 to $387 \mathrm{~mm}$ (table 6) and most were age-1, as determined from length frequencies (fig. 7). In both years, we captured only a few bull trout longer than $200 \mathrm{~mm}$ (table 6, fig. 7).

In 2007, we recaptured two bull trout that were originally PIT tagged in July 2006. The lengths of these fish at tagging were 108 and $162 \mathrm{~mm}$ and their annual growth rates were 57 and $35 \mathrm{~mm}$ (adjusted to 1 year), respectively, with 397 days between tagging and recapture (fig. 7). In 2006, one age-0 (39 mm) bull trout was captured and age- 1 fish were between 100 and 130 $\mathrm{mm}$, as determined from length frequency analysis (fig. 7). Age-0 bull trout captured in August 2007 ranged between 55 and $68 \mathrm{~mm}$, and age-1 fish were from 99 to $155 \mathrm{~mm}$ in length (fig. 7).

In both years, bull trout were found mostly above 2,100 m altitude and in greater numbers and at higher abundances as altitude increased (figs. 8 and 9). Redband trout were found throughout the reaches sampled, but with reduced abundances in the highest altitudes. The middle reach of Pine Creek, which we did not sample in 2006, had the highest abundances of bull trout in 2007, with bull trout $>200 \mathrm{~mm}$ long common. In 2006, only one age-0 bull trout was collected, whereas in 2007, several age-0 fish were captured in the reaches above 2,187 m altitude; figs. 7, 8, and 9). The highest altitude reaches had age-0 bull trout and redband trout present and relatively high abundances of bull trout overall.

Only 14\% of the habitat units surveyed in 2006 contained bull trout, but $83 \%$ of habitat units contained at least one bull trout in 2007. This discrepancy probably was due to more extensive sampling in the middle and upper reaches of Pine Creek in 2007. In 2007, about 10\% of the bull trout were found in pools, though only $9 \%$ of the stream length sampled was pool habitat (table 7).

Jack Creek.- - In both years, sampling in Jack Creek began near the confluence with the West Fork Jarbidge River (fig. 2). In 2006, sampling began 20 m upstream of the PTIS (rkm 0.1) and continued to about rkm 4.3. We stopped sampling near this area because of fish spawning activity. On September 11, 2006, two pair of post-spawn bull trout were collected and several redds were observed. In 2007, our sampling began at the mouth of Jack Creek, continued to rkm 5.9, and included a mark-recapture population estimate presented below. This sampling extended about 100 m past the uppermost distribution of fish, which appears to end at a small waterfall with a $60 \mathrm{~m}$ bedrock slide downstream. On September 11, 2007, $0.8 \mathrm{~km}$ of stream was sampled above the presumed end of fish distribution, and no fish were observed. In early September 2006, 66 of the 70 bull trout captured were PIT tagged (table 1). In early August 2007, 101 of the 146 bull trout captured were PIT tagged (table 2, fig. 2). The minimum fork length was $61 \mathrm{~mm}$ in 
2006 and $42 \mathrm{~mm}$ in 2007, and the maximum fork length was 310 and $283 \mathrm{~mm}$ (table 6), respectively. Most of the bull trout were age-1, with small percentages larger than $200 \mathrm{~mm}(11 \%$ in 2006, $10 \%$ in 2007; table 6, fig. 10).

We recaptured 10 bull trout in August 2007 that were originally PIT tagged in September 2006. The length of these fish at tagging ranged from 125 to $235 \mathrm{~mm}$. The mean annual growth rate of these fish was $34 \mathrm{~mm}$ (range $=21-44 \mathrm{~mm}$; $\mathrm{SD}=4.8$; fig. 10). Using length-frequency analysis, we determined that age- 0 fish were less than $69 \mathrm{~mm}$ in early September 2006, age-1 bull trout were 115-142 mm, and age-2 bull trout were larger than $145 \mathrm{~mm}$ (fig. 10). In August 2007, age-0 bull trout were $42-62 \mathrm{~mm}$, age-1 fish were 980-140 mm, and age-2 fish were 145$190 \mathrm{~mm}$ (fig. 10).

Consistent with findings in other streams in the upper Jarbidge River watershed, bull trout generally were found in greater numbers and at higher abundances at altitudes above 2,100 $\mathrm{m}$ and in greater numbers and at higher abundances as altitude increased (figs. 11 and 12). Redband trout were found in high abundances in lower Jack Creek below about 2,100 m altitude. Bull trout presence extended 500-600 m upstream of the last observed redband trout in both years in Jack Creek. In 2006, bull trout longer than $200 \mathrm{~mm}$ were found in the middle and upper portions of Jack Creek (fig. 11), but in 2007, fish of this size were found only in one area, at rkm 4.0 (fig. 12). In 2006, age-0 bull trout were found only at altitudes greater than 2,000 m. In 2007, however, age- 0 bull trout were found about $0.5 \mathrm{~km}$ from the confluence, at about rkm 2.2, and also at rkm 4.2 near the high abundance of age- 1 or older bull trout.

Of the $5.2 \mathrm{~km}$ of Jack Creek surveyed in 2006, 29\% of the habitat units contained at least one bull trout. Although only $10 \%$ of the stream length surveyed was pool habitat (table 7), 44\% of the bull trout captured were in pools. In 2007, we surveyed $5.4 \mathrm{~km}$ of stream and $45 \%$ of the habitat units contained at least one bull trout. We captured $39 \%$ of the bull trout in pools, while only $8 \%$ of the length of stream was pool habitat (table 7).

Deer Creek.-On September 10, 2007, we sampled Deer Creek from about rkm 6.9 to 9.4. Several small redband trout were observed, but not counted. No bull trout were observed. The riparian vegetation in the reach sampled was very sparse. The stream had a mean depth of $5 \mathrm{~cm}$ and very limited pool habitat.

Buck Creek.-We sampled two short reaches of Buck Creek (from about rkm 3.6-3.8 and rkm 12.7-13.1) on September 14, 2007. The habitat in Buck Creek was similar to that in Deer Creek. It was about $7 \mathrm{~cm}$ deep, lacked defined pools, and had sparse riparian vegetation. In general, the stream had very low velocity, heavy siltation, and high turbidity. Redband trout were abundant; however, no bull trout were observed.

\section{East Fork Jarbidge River Watershed}

East Fork Jarbidge River.-In 2006, we sampled near the East Fork Jarbidge River antenna site ( $\mathrm{rkm}$ 4.1-4.9) on October 3 and in the wilderness area upstream of the East Fork Jarbidge River/Slide Creek confluence (rkm 15.6) from August 17-19 (fig. 3). No bull trout were captured near the antenna site, but 13 were captured between rkm 16.6 and 24.7 (table 1). Sampling stopped at rkm 24.7 due to time constraints. We sampled the East Fork Jarbidge River (rkm 32.5-35.0) from July 12-14, 2007, and captured 323 bull trout, of which 312 were PIT tagged (table 3, fig. 3). We also sampled $250 \mathrm{~m}$ of an unnamed tributary at about rkm 33.5. Redband trout were absent, but 13 bull trout, ranging from 130 to $238 \mathrm{~mm}$, were captured in this tributary (table 3, fig. 16). We encountered a 2.5-m-high falls with no plunge pool $250 \mathrm{~m}$ upstream of the mouth of the unnamed tributary. We sampled an additional 50-m reach upstream 
of this barrier and found no fish. On the mainstem East Fork Jarbidge River below the confluence of Slide Creek, we recaptured one bull trout on July 17, 2007, that was originally tagged in Fall Creek in August 2006 (table 3, fig. 3). We stopped sampling in 2007 at approximately rkm 35.0 due to time constraints. Visual surveys indicated that fish were likely present for at least another $0.5 \mathrm{~km}$ upstream of our end point based on habitat conditions and water quantity. However, this survey was brief and no fish were directly observed.

The maximum size of fish tended to be larger in the upper East Fork Jarbidge River than anywhere else we sampled. In 2006, bull trout ranged in length from 135 to 260 mm (table 6) and in 2007 from 78 to $400 \mathrm{~mm}$ (table 6). Most of the fish we captured were age-3 or older, with a relatively high proportion of fish longer than $200 \mathrm{~mm}$ (38\% in 2006; 19\% in 2007) (table 6, fig. 13). From length-frequency analysis, we determined that age-1 bull trout were between 78 to 100 mm, age-2 bull trout were between 107 and $143 \mathrm{~mm}$, and age-3 bull trout were $143 \mathrm{~mm}$ and longer in mid-July 2007 (fig. 13). The sample size was too small in 2006 to determine age classes. No age-0 bull trout were observed in the East Fork Jarbidge River during 2006 or 2007.

In 2006, bull trout were uncommon but increased in abundance at altitudes above 2,100 m near the upstream end of our survey (fig. 14). Redband trout were abundant throughout the area sampled in 2006. In 2007, bull trout were present at the downstream end of our sampling (fig. 15), were numerically dominant at about 2,290 m altitude, and were the only salmonid present above 2,320 m altitude. Bull trout abundance decreased upstream of the East Fork Jarbidge River confluence with an unnamed tributary and spring at rkm 33.5. In this area, stream depths were very shallow and the stream contained no surface flow for about $100 \mathrm{~m}$. Surface flow and high numbers of bull trout were present upstream of the no-flow section and the channel substrate primarily was bedrock. On July 14, 2007, the last day of sampling the upper East Fork Jarbidge River, bull trout were the only salmonid present and were relatively abundant. We speculate that high abundance of bull trout continued at least another $0.5 \mathrm{~km}$ upstream as no barriers were present.

In 2007, we recaptured a large bull trout $(400 \mathrm{~mm})$ at our lowermost sampling site in the East Fork Jarbidge River (fig. 3). This same fish was originally tagged in Fall Creek (see appendix, fig. A49) and had grown $40 \mathrm{~mm}$ and nearly doubled its weight in 331 days (440.6 to 767.2 g, table 6). We recaptured no other PIT tagged fish in 2006 from the East Fork Jarbidge River.

We surveyed $8 \mathrm{~km}$ of the East Fork Jarbidge River in 2006 and only 5\% of the habitat units contained bull trout. We found $25 \%$ of the bull trout in pools, while $19 \%$ of the length sampled was pool habitat (table 7). In 2007, the survey in the East Fork Jarbidge River covered a higher altitude reach except for a short 0.4-km reach at the East Fork Jarbidge River/ Slide Creek confluence (fig. 3) and 52\% of the habitat units sampled had bull trout (table 7). Nineteen percent of the bull trout we captured were in pools, while $13 \%$ of the stream length sampled was pool habitat.

Cougar Creek.-We sampled Cougar Creek on July 11-12, 2007, starting at the confluence with the East Fork Jarbidge River and continuing upstream $0.7 \mathrm{~km}$; no bull trout were observed in this reach (table 3 and fig. 3). Several temporary, low-flow fish barriers (mostly substrate and wood) were present. From about rkm 1.2-1.5, we captured one bull trout that was $138 \mathrm{~mm}$ long. From rkm 1.8 to the limit of fish presence at rkm 3.1, we caught six bull trout, ranging in length from 180 to $340 \mathrm{~mm}$ (table 6, figs. 16 and 17). Here, the substrate was bedrock and the stream had a steep gradient above 2,100 m altitude. Although there were several cascading waterfalls and slides in this section, redband trout were relatively abundant. The end of 
fish distribution was a 2.5-m-high falls; we electrofished upstream of these falls an additional $100 \mathrm{~m}$, but no fish were observed. Cougar Creek was not sampled in 2006. Only 4\% of the habitat units contained bull trout in Cougar Creek, and five of the seven bull trout we caught were in pools (table 7).

Fall Creek.-We sampled Fall Creek on August 20, 2006, starting at the confluence with the East Fork Jarbidge River and continuing upstream for about $2.0 \mathrm{~km}$ (fig. 3). On July 15, 2007, we sampled from rkm 1.4 to rkm 3.4, but did not find any fish upstream of rkm 3.2 (fig. 3). In 2006, we captured and PIT tagged nine bull trout (table 1). In 2007, 30 bull trout were captured and PIT tagged (table 3). The combined range of lengths of fish from both years was 79-360 mm (table 6). Most of the bull trout in 2007 were age-1, with only a few age-2 fish present (fig. 18). The sample size of fish in 2006 was too small for age determinations. One bull trout longer than $200 \mathrm{~mm}$ that was PIT tagged in 2006 was subsequently recaptured in 2007 in the mainstem East Fork Jarbidge River (rkm 23.5) near the confluence with Slide Creek, about $2.5 \mathrm{~km}$ from the tagging site.

In 2006, bull trout were uncommon from the confluence with the East Fork Jarbidge River to about $1.0 \mathrm{~km}$ upstream (fig. 19). In 2007, bull trout were found with increasing frequency and abundance in the higher altitudes sampled (fig. 20). Four bull trout longer than $200 \mathrm{~mm}$ were caught near the end of fish distribution (fig. 20). All size classes of redband trout were found throughout the length of stream sampled in 2006. In 2007, redband trout abundance decreased in the upper reaches of Fall Creek, and bull trout were the only salmonid present in the final $130 \mathrm{~m}$ of stream below a barrier waterfall.

Of the $2.0 \mathrm{~km}$ of Fall Creek surveyed in 2006, only $8 \%$ of the habitat units contained bull trout. Twenty-two percent of the catch was from pools, and 14\% of the stream length was pool habitat. Of the $1.8 \mathrm{~km}$ of stream sampled in 2007, 28\% of the habitat units contained at least one bull trout, with $20 \%$ of the fish found in pools. Only $9 \%$ of the stream length sampled was pool habitat (table 7).

Slide Creek.-On August 21, 2006, we sampled Slide Creek from its confluence with the East Fork Jarbidge River upstream to rkm 5.5, where we observed spawning bull trout. We did not sample two small sections in 2006, one from rkm 2.9 to rkm 3.2 and another from rkm 4.6 to rkm 5.4 (table 1, fig. 3). On July 16, 2007, we sampled the creek from rkm 4.6 to rkm 7.7 (table 3 and fig. 3). In 2006, four bull trout were captured and PIT tagged (table 1) and in 2007, only three fish were captured and PIT tagged (table 3). The length of bull trout ranged from 189 to $300 \mathrm{~mm}$ in 2006 and from 95 to $220 \mathrm{~mm}$ in 2007 (table 6 and fig. 21). On August 22, 2006, we observed two gravid bull trout (300 and $190 \mathrm{~mm}$ ) and another spawning pair and therefore stopped sampling. In 2006, all four of the bull trout were captured at an altitude above 2,100 m (fig. 22). In 2007, two of the bull trout we caught were likely age-1 fish, on the basis of estimates of size at age from other fish in the East Fork Jarbidge River (fig. 21). The lengths of the few bull trout caught in 2007 varied widely, and the largest fish $(220 \mathrm{~mm})$ was caught very high in the watershed (fig. 23). No bull trout were caught in pools in either year (table 7, figs. 22 and 23). All size classes of redband trout were found throughout Slide Creek in 2006 and 2007. Sampling efficiency generally was less in Slide Creek relative to that in other streams due to narrow stream width and thick riparian vegetation.

Dave Creek.-In August 2006, we collected samples between rkm 6.8 and rkm 11.7 on Dave Creek and PIT tagged 111 of the 129 bull trout collected (table 1, fig. 3). We stopped sampling on August 6 because we encountered one sexually mature male bull trout and two bull trout paired together over spawning gravel. From June 28 through July 2, 2007, sampling started 
at rkm 6.8 and ended $80 \mathrm{~m}$ upstream of the last fish observed (at about rkm 14.0). We also repeated sampling from rkm 10.5 to 13.9 on September 11, 2007, to recapture PIT tagged fish for estimating summer growth rates. From June 28 through July 2, 2007, 105 bull trout were captured and 100 of these were PIT tagged (table 3, fig. 3). In September, a total of 23 bull trout were captured and 11 were newly PIT tagged. Seven recaptured bull trout were originally PIT tagged during our June 2007 sampling and three bull trout were recaptures from 2006. During this time, we captured three sexually mature, male bull trout, ranging in length from 153 to 200 mm.

The lengths of bull trout captured from Dave Creek in 2006 ranged from 97 to $229 \mathrm{~mm}$ (table 6). Most of the fish were age-1, with a few being longer than $200 \mathrm{~mm}$ (12\% of the total catch; table 6, fig. 24). In 2007, the lengths ranged from 59 to $232 \mathrm{~mm}$, and only $5 \%$ of the fish were longer than $200 \mathrm{~mm}$ (table 6).

We recaptured three bull trout in Dave Creek during 2007 that were originally PIT tagged in 2006. These fish ranged from 108 to $114 \mathrm{~mm}$ at tagging and their mean annual growth rate was $37 \mathrm{~mm}$ (range $=35-39 \mathrm{~mm}$; $\mathrm{SD}=2.2$; fig. 24). Using length frequency analysis, we determined age-1 bull trout fork lengths to range from 97 to $134 \mathrm{~mm}$ and age-2 fish ranged from 140 to $180 \mathrm{~mm}$ in early August 2006 (fig. 18). We also recaptured seven bull trout in September 2007 that were tagged in June 2007. The mean growth of these fish over 68 days was $11 \mathrm{~mm}$ (range: 1-22 mm). In late June 2007, the fork length of age-1 bull trout ranged from 83 to 127 $\mathrm{mm}$ and age-2 fish were estimated to be between 140 and $175 \mathrm{~mm}$ (fig. 24). In September 2007, we did not collect enough fish to make a length frequency analysis; however, we collected four bull trout fry that ranged in length from 59 to $66 \mathrm{~mm}$.

In both years, bull trout were found in greater numbers and in higher abundances as altitude increased (figs. 25 and 26). Redband trout were present throughout Dave Creek, but abundance decreased at higher altitudes. In 2006, bull trout larger than $200 \mathrm{~mm}$ commonly were mixed with smaller fish (fig. 25). In 2007, however, bull trout larger than $200 \mathrm{~mm}$ primarily were found at high altitudes (fig. 26).

We surveyed $4.9 \mathrm{~km}$ of Dave Creek in 2006 and $46 \%$ of the habitat units contained bull trout. About $15 \%$ of the bull trout were found in pools and $7 \%$ of the length of stream sampled was pool habitat (table 7). In 2007, 62\% of the habitat units had bull trout, $10 \%$ of the bull trout were found in pools, and only $2 \%$ of the survey length was pool habitat.

\section{Overall Distribution and Abundance of Bull Trout in Jack Creek}

In 2007, we estimated the population for age-1 or older bull trout in the fish-bearing portion (lower $5.3 \mathrm{~km}$ ) of Jack Creek. Because of the low number of bull trout captured in the lower section of Jack Creek (downstream of Jenny Creek, $n=6$, with 2 recaptured bull trout), we did not calculate a population estimate in that section. In the $3.6 \mathrm{~km}$ upstream of Jenny Creek, we captured and marked 66 bull trout during our first effort, and during our second effort, 23 of the 52 fish collected had marks from the initial sampling. This yielded a population estimate of 153 bull trout $(\mathrm{SD}=17.5 ; \mathrm{CV}=11.9$; 95\% CI = 114-220). During our recapture efforts in upper Jack Creek, we collected 35\% of the fish tagged the day before. In our recapture efforts in lower Jack Creek, we collected 33\% of the fish tagged the day before. This indicates that our one-pass electrofishing effort had a catchability of $35 \%$ over the $5.3 \mathrm{~km}$ of stream. 
For the streams in which bull trout were present, regression analysis indicated a significant correlation $\left(P<0.001, \mathrm{R}^{2}=0.06\right)$ between bull trout abundance and altitude. We also found a highly significant correlation $\left(P<0.001, \mathrm{R}^{2}=0.01\right)$ between the number of bull trout (per $\mathrm{m}$ ) and pool depth. The low $\mathrm{R}^{2}$ values indicate that although altitude and pool depth have a significant relationship to bull trout abundance, they explain only a small amount of the variation. We should make clear that bull trout abundance was relative because we conducted only a single upstream sampling pass with no block nets, and capture efficiency was variable due to several factors (temperature, light, crew experience, substrate, for example). No other relations were evident between the relative abundance of bull trout and other habitat features that were quantified, such as pool cover (large and small wood, substrate, and undercut bank), riparian shade, and wetted width.

\section{Movements of Bull Trout}

In 2006, the PTISs at West Fork Jarbidge River (rkm 15.0), East Fork Jarbidge River (rkm 4.1), and Jack Creek (rkm 0.1) were operated from September 15 to December 18, 2006, when they were removed for the winter. During that time, five bull trout were detected moving downstream at the West Fork Jarbidge River site, with one of these fish first detected by the PTIS in Jack Creek (table 8; figs. A3, A14, A26, and A28). Three of the five fish were tagged in the West Fork Jarbidge River, one was tagged in Pine Creek, and one in Jack Creek. All fish were detected moving downstream after October 7, 2006 (figs. A3, A14, A26, A28, and A30). We detected no fish on the PTIS at the East Fork Jarbidge River site.

In 2007, we re-installed and operated the PTISs in the West Fork Jarbidge River, East Fork Jarbidge River, and Jack Creek and also installed a system in Dave Creek, at the confluences of the West Fork Jarbidge River and Pine Creek and the East Fork Jarbidge River and West Fork Jarbidge River at the Forks (table 8). All systems were operated from April to mid-December. Although the single antenna systems in Jack and Dave Creeks were intermittently affected by antenna noise that may have reduced their detection efficiency (fig. 27), test tags passed weekly through these systems indicated no such loss in efficiency. The larger MUX systems were, in general, fully operational (fig. 27), but some conditions, such as low battery power, electronics malfunctions, and extreme temperatures may have reduced their detection efficiency. Maintaining an adequate battery voltage, by charging with solar power or replacing batteries, was difficult as winter approached because of the remote location combined with decreased sunlight and temperatures.

Three upstream and four downstream directional movements of bull trout were detected at the PTIS on the East Fork Jarbidge River at Murphy Hot Springs or the East Fork and West Fork PTIS antennas at the Forks (fig. 28). In both years, the majority (83\%) of fish interrogated at the three PTISs in the West Fork Jarbidge River were moving downstream (fig. 29). However, two fish moved upstream in Jack Creek and one fish moved upstream at the mainstem West Fork Jarbidge River PTIS at rkm 15. The upstream movements of fish in Jack Creek occurred in late spring as the main West Fork Jarbidge River approached base flows and water temperatures increased.

Appendix figures A1 through A50 show all data for fish interrogated in 2006 and 2007, and fish that showed evidence of movement by recapture. There were 44 new interrogations of PIT tagged bull trout in 2007 (table 8), and one fish from Jack Creek that was interrogated in both 2006 and 2007 (fig. A3). Most fish that were detected were tagged in the West Fork Jarbidge River or its tributaries, but two fish were tagged in Dave Creek. In Dave Creek, one fish 
(195 mm) was tagged in August 2006 and detected on April 29, 2007, at the PTIS in the East Fork Jarbidge River at Murphy Hot Springs. The other bull trout (164 mm) was tagged in Dave Creek on June 28, 2007, and detected at both the East Fork and West Fork PTIS antennas at the Forks on July 28, 2007, but this fish was not detected at the PTIS on Dave Creek (installed on May 23, 2007) or the PTIS on the East Fork Jarbidge River at Murphy Hot Springs (figs. A1 and A2). Both of these fish were tagged in a similar location.

Bull trout in Jack Creek showed several movement patterns, with fish tagged at relatively high altitudes in the drainage basin leaving the creek and inhabiting the West Fork Jarbidge River, the East Fork Jarbidge River, and presumably the mainstem below the Forks. In 2007, only two bull trout were detected by the PTIS in the West Fork Jarbidge River (rkm 15), and they were tagged in Jack Creek (table 8). Fish tagged in the upper reaches of Jack Creek tended to emigrate in mid-July (figs. A4 through A8 and A10). For example, one bull trout (175 mm) tagged near the upper end of fish distribution in 2006 was detected moving out of Jack Creek on July 13, 2007. This fish was detected moving past the PTIS at the Forks on November 20, 2007 (fig. A6). Another bull trout (138 mm) tagged in the upper reaches was detected on the Jack Creek PTIS on July 21, 2007. This fish was then detected 2 days later moving downstream through the PTIS at the Forks (fig. A7). Two fish (138 and $171 \mathrm{~mm}$ ), tagged in the lower sections of Jack Creek in early August 2007, were detected emigrating from the creek in November 2007 (figs. A11 and A12). Finally, one bull trout tagged in the upper reaches of Jack Creek in September 2006 was detected on the PTIS at the East Fork Jarbidge River at Murphy Hot Springs moving downstream on August 26, 2007, and was detected later on October 19, 2008, in the West Fork Jarbidge River at the Forks moving upstream (fig. A9)

The PTIS at the confluence of the West Fork Jarbidge River and Pine Creek had many more fish detections than any of the other PTIS locations (table 8). Fish tagged in the upper West Fork Jarbidge River had the highest number of interrogations, with 20 fish detected at the West Fork Jarbidge River/Pine Creek site (table 8). Ninety percent of these fish were moving down the West Fork Jarbidge River from September through November (fig. 29). Ten of the fish tagged in the West Fork Jarbidge River were detected or recaptured in Pine Creek, indicating a relatively high degree of connectivity between these watersheds (figs. A21, A22, A24, A25, A27, A35, A39, A42, A44, and A48). We detected eight fish at the West Fork Jarbidge River/Pine Creek site that were tagged in Pine Creek, seven of which were emigrating downstream between October 7 and November 4, 2007. The eighth fish was detected moving downstream at the same time of year on November 3, 2006, at the PTIS on the West Fork Jarbidge River (rkm 15), however, the PTIS at West Fork Jarbidge River/Pine Creek (rkm 26.2) was not established until 2007 (fig. A14). Bull trout were detected at the West Fork Jarbidge River/Pine Creek site continuously during the summer and detections decreased as winter approached (fig. 29). Bull trout were detected at the interrogation systems nearly all hours of the day, but with a higher frequency during the night (fig. 30).

\section{Distribution, Growth, and Movement of Bull Trout}

Findings from the 2006 and 2007 electrofishing surveys suggest that bull trout populations with recruitment to age- 1 fish occurred in Pine, Jack, Dave, and Fall Creeks as well as the West Fork and East Fork of the Jarbidge River at altitudes above 2,100 m. Few bull trout were observed in Cougar and Slide Creeks, indicating that stable reproductive populations were not present in those creeks at the time of the survey. The results of the genetic analysis reporting on the relatedness between sub-populations of bull trout from the streams described above were 
highly supportive of our distribution and movement findings and can be found in DeHaan and others (2007). No bull trout were found in Deer and Buck Creeks, however, migratory bull trout may inhabit those streams intermittently.

\section{General Catch Information and Population Characteristics}

During 2 years of sampling in the upper Jarbidge River watershed, we captured 1,702 bull trout (80\% of which were captured in 2007) and counted more than 4,000 redband trout in pools only. Bull trout were found primarily at altitudes above 2,100 m (87\% of all those encountered), which was consistent with the findings in other studies that the distribution of juvenile bull trout within streams was strongly associated with altitude (Dunham and Rieman, 1999; Paul and Post, 2001; Dunham and others, 2003a; Ripley and others, 2005).

Redband trout were found in all areas where bull trout were sampled, except in the upper reaches of fish distribution in East Fork Jarbidge River and Jack Creek, where bull trout were the only salmonid present. In streams with notable bull trout populations (such as the headwaters of the East Fork and West Fork Jarbidge River, and Dave, Fall, Pine, and Jack Creeks), the relative abundance of redband trout decreased as the upper limit of fish distribution was approached. The relative abundance of bull trout tended to increase and that of redband trout decreased with increasing altitude. One explanation for the change in numerical dominance of bull trout over redband trout with altitude is that altitude can serve as a surrogate for stream temperature (Dunham and others, 2003b; Rieman and others, 2007). In upper reaches of those studies, most streams had an abundance of cobble and boulder substrates with interstitial spaces for cover, and relatively cool temperatures, conditions typical of good bull trout habitat in other streams (Fraley and Shepard 1989; Rieman and others, 2007). The ability of bull trout to dominate the upper, higher altitude reaches of streams could be due to their superiority in interspecific interactions, and may be an example of biotic resistance exerted by bull trout (Elton, 1958). Biotic resistance through predation, which can contribute to invasion or colonization resistance (Harvey and others, 2004; Ward and others 2008), seems probable given the highly piscivorous nature of bull trout (Fraley and Shepard, 1989; Donald and Alger, 1993).

The distribution of bull trout and redband trout in streams of the Jarbidge River basin could change if temperatures increase due to climate change or other factors. For example, increasing stream temperatures could favor redband trout, leading to an expansion of their distribution, restricted distributions of bull trout, and a decrease in the competitive ability of bull trout (Rieman and others, 2007). When bull trout distributions become restricted, they may be unable to reclaim dominance to their full historical range because of biotic resistance from redband trout occupying those reaches. In short, on the basis of potentially higher stream temperatures alone, more habitat would be suitable for redband trout and less for bull trout. The area of transition in dominance of bull trout over redband trout, however, may be an important aspect to monitor relative to the sustainability of bull trout in the Jarbidge River watershed.

Using a mark-recapture procedure, we estimated that there were about 153 bull trout in Jack Creek upstream of Jenny Creek $(95 \%$ CI $=114$ - 220). Our estimate was similar to that of a single pass survey by NDOW, which reported about 102 bull trout for the entire Jack Creek in 2002 (Johnson, 2002). From the mark-recapture data, our one-pass capture efficiency was estimated to be $35 \%$, and methods similar to ours could be used to evaluate changes in bull trout abundance over time in Jack Creek. In fact, estimating the abundance of bull trout in Jack Creek could become a routine method for status and trends monitoring in the Jarbidge River basin. We do not, however, recommend extrapolating our sampling efficiency estimate from Jack Creek to 
other streams to estimate fish abundance by simply dividing the number of fish captured in a stream by 0.35 to obtain an estimate of abundance. Electrofishing sampling efficiency can vary widely depending upon many factors, including crew experience, equipment type, fish size, fish abundance, stream width, stream flow, temperature, water clarity, cloud cover, and sun position (Zalewski and Cowx, 1990). It seems prudent to keep Jack Creek as a status and trends monitoring site for future bull trout population abundance estimates and perhaps to establish reference sites in other streams to monitor relative abundance.

Length-frequency distributions of bull trout in streams of the upper Jarbidge River watershed were generally similar and were dominated by age- 1 and age- 2 fish. This is indicative of good reproduction success and suggests that older bull trout might show a fluvial life history and therefore be absent from our sample. An exception to this conclusion was found in the upper East Fork Jarbidge River (sampled in 2007), which was dominated by age-3 or older fish, although it should be noted that the uppermost fish distribution was not reached and there may have been younger fish in this area. The dominance of older fish suggests that the numbers of age-1 and age-2 fish were suppressed by predation (cannibalism) or that younger fish emigrate to rear in the lower mainstem East Fork Jarbidge River or tributaries. Beauchamp and Van Tassell (2001) found that bull trout of all sizes were capable of eating fusiform prey fishes of up to 50\% of their own total length. They also used model simulations and field data to show that cannibalism by bull trout could remove substantial proportions of age- 0 and age- 1 fish, but not age-2 or older fish in Lake Billy Chinook, Oregon. Diet analysis of piscivorous-sized bull trout would be required to confirm this notion in the upper East Fork Jarbidge River.

The length of age- 1 bull trout varied temporally, ranging from $68 \mathrm{~mm}$ in the West Fork Jarbidge River on June 21, 2006, to $145 \mathrm{~mm}$ in Pine Creek on August 22, 2007, similar to fish in other basins, such as the Flathead River, Montana (Fraley and Shepard, 1989), Metolius River, Oregon (Ratliff, 1992), Kananaskis Lake in Alberta, Canada (Stelfox, 1997), and the Cedar River, Washington (M. Mesa, U.S. Geological Survey, unpub. data, 2008).

Age-0 bull trout probably did not begin to emerge until late June or later in most tributaries of the upper Jarbidge River watershed. We collected 5 age- 0 bull trout in 2006 and 83 in 2007. Our sampling did not target age-0 fish; however, the lack of very small $(<30 \mathrm{~mm})$ fish in our catches probably reflects the timing of our sampling and the low susceptibility of this portion of the age group to our sampling gear. Small fish are less vulnerable to capture by electrofishing than are larger fish, they are less visible to netters, and their body size facilitates hiding in interstitial spaces of the streambed material (Reynolds, 1983). Low numbers of age-0 bull trout observed in most streams was probably not a result of poor hatching success or low survival. However, given the high numbers of bull trout collected in the upper East Fork Jarbidge River and Fall Creek, we speculate that if age- 0 fish were present at that time of year, we would have at least observed some of them.

By examining length-frequency distributions and assigning ages to the distinct modes, we estimated the age and growth rates for younger bull trout. This technique worked well for age-0 and age- 1 fish, but not for older fish. The largest age- 0 fish we collected was $69 \mathrm{~mm}$ and most age-1 fish were larger (range: $78-145 \mathrm{~mm}$ ). It was more difficult to estimate the size ranges of age- 2 or older bull trout because individual growth rates were highly variable and the age breaks between age- 2 and age-3 fish were unclear. Recapturing PIT tagged bull trout allowed us to validate the age assignments of the length frequency histograms and to estimate the growth rates of older age classes. 
Although the sample sizes of recaptured PIT tagged fish in any stream during our study were small, they were sufficient to provide some insight into annual growth rates. Of the 25 fish tagged in 2006 that were recaptured in 2007, 3 were from Dave Creek, 1 from East Fork Jarbidge River, 5 from Pine Creek, 6 from West Fork Jarbidge River, and 10 from Jack Creek. The mean annual growth rate was $36 \mathrm{~mm}$ for all recaptured bull trout $(\mathrm{n}=23)$ and ranged from $32 \mathrm{~mm}$ in the West Fork Jarbidge River to $38 \mathrm{~mm}$ in Pine Creek. These mean annual growth rates compare favorably with those of bull trout in other areas, such as $28 \mathrm{~mm}$ in Trestle Creek, Idaho (Downs and others, 2006). There are several possible reasons for the low number of fish tagged in 2006 being recaptured later. First, because the number of tags deployed in 2006 was much fewer than in 2007, there were simply fewer tagged fish available in 2007 that were tagged in 2006. Second, our sampling in 2006 generally took place lower in the watersheds compared to our work in 2007, when we focused activity towards the upper end of fish distribution. Third, the probability of over-winter mortality of fish in the basin seems high (because of low winter flow, anchor ice formation, and relatively sparse abundance of deep pools in areas where bull trout were more common), which would reduce the recapture potential. It is possible that some shedding of PIT tags occurred. Although we tagged all bull trout greater than 120 -mm fork length in the dorsal sinus to minimize tag loss, we do not know the rate of tag loss for bull trout tagged in this area. Dieterman and Hoxmeier (2009) found that brook trout and brown trout (Salmo trutta) tagged in the dorsal musculature had high tag retention rates-100\% and 95\%, respectively, over 2 months in small streams. Finally, there also is a possibility that tagged fish emigrated out of the area sampled in 2007. If this movement occurred when the PTISs were not operating, we would not be aware of it. All these factors could contribute to low recapture rates of PIT tagged bull trout on an annual basis.

There was no clear longitudinal gradient in fish size or propensity to emigrate as we progressed from downstream to upstream areas in the Jarbidge River watershed. Some studies have shown that fish become smaller with progression upstream, because fish size was related to stream depth observed at the habitat unit scale (see, for example, Patrick. 1975; Schlosser, 1982; Anderson, 1985). Hughes (1998) suggested, however, that this relationship does not always apply to drift-feeding stream salmonids. The lack of a longitudinal gradient in bull trout size in our streams was probably due to the relatively small size of our streams and that bull trout can show considerable intra-stream movements (see discussion below), which would help distribute fish of different sizes throughout the stream.

\section{Movement of Bull Trout}

In general, the PTISs were effective at detecting upstream and downstream movements of bull trout and documenting connectivity between headwater and mainstem areas. Bull trout were detected moving from upper ends of fish distribution in the West Fork Jarbidge River $(n=13)$, Pine Creek $(n=5)$, and Jack Creek $(n=7)$ to the lower West Fork Jarbidge River below the confluence with Jack Creek. Fish from Jack $(n=4)$ and Dave $(n=1)$ Creeks were detected at the confluence of the East Fork and West Fork Jarbidge River. When the data on fish movements detected by the PTISs through December 2007 are combined, they indicate some degree of connectivity between headwater populations and the mainstem East Fork Jarbidge River and West Fork Jarbidge River.

There was a pulse of downstream movement of fish in October and November 2007 from Pine Creek, West Fork Jarbidge River (rkm 26), and Jack Creek, most likely associated with declining temperatures and a slight increase in flow. While downstream movements of fish at the 
West Fork Jarbidge River and Pine Creek confluence PTIS (at rkm 26) peaked in October, downstream movement was detected at that site in all months that the PTIS was operating. Downstream movement by bull trout in the fall has been documented in other systems, including the Flathead River system in Montana (Muhlfeld and Marotz, 2005), the Boise River in Idaho (Monnot and others, 2008), Trestle Creek in Idaho (Downs and others, 2006), Grand Ronde River system in Oregon (Bellerud and others, 1997), and the Arrow Lakes region in British Columbia (McPhail and Murray, 1979). Bull trout in the Grand Ronde system were fluvial fish and those in the Flathead River, Boise River, Trestle Creek, and the Arrow Lakes region had adfluvial life histories. All these studies suggest that the autumn emigration of juvenile bull trout correlates with decreasing water temperatures. There also were some downstream movements of fish out of Jack Creek in mid-July with some of these fish detected moving down the West Fork Jarbidge River past the Forks within a few days, and some even entering the East Fork Jarbidge River. It appears that some bull trout, particularly from Jack Creek, migrate downstream of the Forks and inhabit the mainstem Jarbidge River, but the extent or duration of mainstem habitat use is unclear. In the Flathead River system, juvenile bull trout emigrated primarily from June through August (Fraley and Shepard, 1989).

Detections of upstream movement of bull trout were relatively rare (17\% of all movement detected from PTISs) compared with detections of downstream movement. However, most of the fish we tagged were juvenile fish that may not become migratory for several years. Most of the upstream movements (62\%) were detected at the Pine Creek and West Fork Jarbidge River confluence (rkm 26). These fish appeared to be moving back and forth, potentially rearing in the vicinity of the PTIS. Other upstream movements of fish were detected at PTISs at West Fork Jarbidge River (at rkm 15) and Jack Creek. These upstream movements occurred in June 2007 as the West Fork Jarbidge River flows were decreasing and water temperatures were increasing. Other investigators have found that peak upstream movements of fluvial bull trout in Montana's Blackfoot River occurred during the spring as water temperatures were increasing (Swanberg, 1997; Homel and Budy, 2008). These fish may have been on spawning migrations. As evidence of this, the largest bull trout tagged in Jack Creek (310 mm) out-migrated in October 2006 and returned the following June to Jack Creek (fig. A3). Seasonal movement of juvenile bull trout (upstream migrations in the spring and downstream in the fall) have been reported by others in Trestle Creek, Idaho (Downs and others, 2006) and South Fork Walla Walla River, Oregon (Homel and Budy, 2008). Continued operation of the PTISs in the Jarbidge River basin would allow for additional detections to confirm these life history trends for migrating fish.

Seasonal fish barriers, primarily downed wood and substrate, were present during low flows in the West Fork Jarbidge River upstream of Pine Creek and in lower Cougar Creek. Similar temporary barriers may form in any of the streams we sampled, may not be present every year, and likely form during low-flow conditions. Such conditions may prevent bull trout from reaching areas used for spawning or rearing, thus isolating some fish in tributaries intermittently. Because bull trout may access their spawning areas during low-flow conditions in the fall, these temporary barriers may decrease inter-annual distribution, but increase straying and gene flow among certain populations. This may be true of the bull trout in the upper West Fork Jarbidge River and Pine Creek populations as well as the Cougar Creek and East Fork Jarbidge River populations, although there was little evidence of juvenile recruitment in Cougar Creek during our survey. 
Results from this and other studies (Fraley and Shepard, 1989; Rieman and MacIntyre 1993; Bellerud and others, 1997; Haas and McPhail, 2001) show substantial variation in migration behavior of bull trout, which is associated with many factors, including water temperatures, stream discharge, fish size, food availability, and spawning. Bull trout also can be highly migratory during non-spawning periods (Muhlfeld and others, 2003; Downs and others, 2006; Brenkman and others, 2007). The movements of bull trout in the Jarbidge River system indicate a high degree of connectivity between fish in different streams. Maintenance and potential enhancement of this connectivity will likely promote expression of important life history diversity (Muhlfeld and Marotz, 2005), which would contribute to the persistence of the population under varying habitat and climate conditions (Dunham and others, 2003a; Rieman and others, 2007).

Most of the bull trout (89\%) emigrating downstream in the Jarbidge River basin were age-2 or older, with a few age-1 fish migrating from the West Fork Jarbidge River, Pine Creek, and Jack Creek. The fish detected at the PTISs tended to be the larger individuals within their age class. Although we cannot know the actual length of a tagged fish at the time of detection, we assumed that the size of fish at tagging was representative of its size relative to its cohort when detected. Our results were consistent with others describing an emigration of smaller bull trout (for example, Fraley and Shepard, 1989; Bellerud and others, 1997; Downs and others, 2006). Fraley and Shepard (1989) reported that $81 \%$ of the emigrating juvenile bull trout from the Flathead River system were ages 2 and 3. Mogen and Kaeding (2005) also observed that juvenile bull trout commenced migrations at age 2 or 3 . Because larger fish may have a greater burst swim speed ability (Mesa and others, 2004), and would be less vulnerable to predation due to their larger size, migrating at a larger size could increase survival probability. A similar situation could exist in the Jarbidge River where emigrating at a relatively large size might have survival advantages and play a role in the persistence of a fluvial life history.

We were unable to estimate the efficiency and precision of the PTISs in the Jarbidge River basin because of their configuration or an insufficient number of detections. Too few detections were available to estimate detection efficiencies for the systems with multiple antenna arrays. Estimating antenna efficiencies in Dave or Jack Creeks was not possible because there was only one antenna at each site. However, the efficiency of any PTIS would vary over time and is influenced by stream discharge, the direction of fish movements, intermittency in PTIS operation due to low battery power, and malfunctioning electronics.

We maintained a reasonably good record of operation at the sites and continued to improve antenna anchoring and electronic system stability. Because our systems were based on the designs used by Connolly and others (2008) and the sizes of our streams were similar to those in their study, we surmise that detection efficiencies of our systems were good when the complete detection systems were intact. Their work showed that detection efficiencies of multiple antennas arranged in a series of arrays exceeded 96\% under a variety of dynamic stream conditions. The systems tested by Connolly and others (2008) had three arrays, so that if any one array failed, two other arrays would still be able to determine the direction of fish movement and allow an estimate of detection efficiency. The systems in the Jarbidge River consisted of one or two arrays, and therefore had less redundancy, a reduced ability to determine the direction of movement or calculate detection efficiencies, and likely lower detection efficiencies than the systems described in Connolly and others (2008). 


\section{Conclusions, Summary, and Recommendations}

Prior to the study described here, little was known about the bull trout population in the upper Jarbidge River basin, and biologists estimated that fewer than 500 bull trout were present within the core area defined by the U.S. Fish and Wildlife Service (2004). Our results indicate that almost four times that many bull trout inhabit the core area and that these fish show substantial movements between tributaries, increased abundance with increasing altitude, and growth rates indicative of a high-quality habitat. Our estimate of population size of bull trout in Jack Creek should provide a baseline that will allow managers to monitor changes in abundance over time. Further, our work included some information on the abundance of redband trout that provides an understanding of the distribution of these fish relative to that of bull trout.

Collectively, our results provide new insight into the ecology and biology of bull trout in the upper Jarbidge River watershed that should prove useful for developing recovery actions and managing these fish.

Our research was successful in documenting some important population and movement characteristics of bull trout in the Jarbidge River basin. We documented the relative abundance of bull trout throughout the watershed, their annual and seasonal growth rates, the timing and magnitude of downstream migrations, and the timing of the onset of spawning. Bull trout were found primarily in the upper parts of tributaries at altitudes greater than 2,100 $\mathrm{m}$ and numerically dominated redband trout in the upper East Fork Jarbidge River and Jack Creek. Redband trout, however, were more numerous throughout the rest of the watershed. Bull trout from the upper East Fork Jarbidge River, upper West Fork Jarbidge River, and Dave, Jack, and Pine Creeks had length-frequency distributions indicative of healthy populations with good potential for growth in body size and number. The annual growth rates of individual bull trout in the basin ranged from 21 to $61 \mathrm{~mm}$ and were indicative of good habitat conditions and within the range reported for bull trout elsewhere. Although bull trout showed some downstream movement during the spring and summer, most of their emigration occurred in autumn. Most of the fish that moved downstream were age-2 or older, which is typical of bull trout in other areas. We do not know the extent or timing of emigrations of age-0 fish, an important omission from this study.

We do not know the contribution of different age classes and life history strategies to juvenile and adult production. Certainly, maintaining the expression of life history diversity, spread over multiple age classes, will help these fish survive temporal habitat disturbances. The contribution of various life history strategies expressed by juvenile bull trout could be evaluated, at least in part, by simply maintaining the current network of PIT tag interrogation systems. Much effort was expended to PIT tag juvenile bull trout, and those with successful life history strategies will mature and should be detectable by the interrogators used in this project for years to come, as well as by recapture when electrofishing or trapping. With a minimum of maintenance, PIT tag interrogators should be able to collect data documenting the timing of spawning migrations and periods when fluvial, adult fish use river and stream habitat. Because the PIT tag interrogation systems continued to operate in 2008 and 2009, additional information on fish movements was collected and more information will be available about the success of different juvenile life histories and from adult fish behavior and use of tributaries in the Jarbidge River basin. In addition, and of substantial ecological and management significance, the PTISs and the resultant data they provide will establish a baseline for monitoring changes in fish behavior in response to future environmental changes. 
To document changes in the Jarbidge River bull trout population over time, we suggest a sampling regime that combines a broad comparison of relative fish abundance and distribution in several tributaries with a more detailed population estimate in one or more streams. For now, we suggest that a mark-recapture population estimate be conducted in Jack Creek every 3-5 years. We also suggest monitoring fish population trends via single-pass electrofishing in upper West Fork Jarbidge River, Pine Creek, and Dave Creek at regular intervals, such as every 3 to 5 years. These streams should be targeted based on their relative bull trout abundance and the ease of accessibility for field crews. We expect that as repeated measures become available, trends in population characteristics should become evident.

\section{Acknowledgments}

We want to acknowledge all the members of the Bull Trout Recovery Team, especially Selena Werdon and Allen Taylor of the USFWS, for their involvement, interaction, and funding support. We thank Steven Buschback, Emily Hite, Jason Olds, Dawn Hunt, Carrie Munz, and Brien Rose of United States Geological Survey's Columbia River Research Laboratory for working tireless hours in the field. We thank Kate Forster, Daniel Armichardy, Jessica Stegmeier, Matthew Kowalski, and Josh Uriarte from the Bureau of Land Management in Twin Falls for their placement of thermographs, collection of water temperature data, and assistance in fish sampling and maintaining and downloading the PIT tag interrogation systems. We also thank the personnel at the United States Forest Service, Wells District Ranger Station for use of the Mahoney facility for housing and equipment storage. Krinn and Chuck McCoy of the Tshawhawbitts Bed and Breakfast hosted the field crew and provided information on the area. We would like to recognize Gary Johnson and Caleb Cotton of Nevada Department of Wildlife for their help maintaining the PIT tag interrogation systems. We appreciate the many volunteers for the pack trips and the horse pack leaders in 2006 and 2007. We thank Kenney Baird for allowing us to store equipment on his property; and we thank the citizens of Jarbidge, Nevada, for their patience and many interesting conversations.

\section{References}

Anderson, C.S., 1985, The structure of sculpin populations along a stream size gradient: Environmental Biology of Fishes v. 13, p. 93-102.

Bain, M.B., and Stevenson, N.J., 1999, Aquatic habitat assessment-Common methods: American Fisheries Society, Bethesda, Md., p. 149-155.

Beauchamp, D.A., and Van Tassell, J.J., 2001, Modeling seasonal trophic interactions of adfluvial bull trout in Lake Billy Chinook, Oregon: Transactions of the American Fisheries Society, v. 130, p. 204-216.

Bellerud, B.L., Gunkel, S., Hemmingsen, A.R., Buchannan, D.V., and Howell, P.J., 1997, Bull trout life history, genetics, habitat needs, and limiting factors in central and northeast Oregon, Annual Report to the Bonneville Power Administration, Project 95-64, Portland, Oreg.

Bisson, P.A., Montgomery, D.R., and Buffington, J.M., 2006, Valley segments, stream reaches, and channel units, pg. 23-49 in Hauer, F.R., and Lamberti, G.A., eds., Methods in stream ecology: Academic Press, Burlington, Mass.

Brenkman, S.J., Corbett, S.C., and Volk, E.C., 2007, Use of otolith chemistry and radiotelemetry to determine age specific migratory patterns of anadromous bull trout in the Hoh River, Washington: Transactions of the American Fisheries Society, v. 136, p. 1-11. 
Connolly, P.J., Jezorek, I.G., Martens, K., and Prentice, E.F., 2008, Measuring performance of two stationary interrogation systems for detecting downstream and upstream movement of PIT-tagged salmonids: North American Journal of Fisheries Management, v. 28, p. 402-417.

Connolly, P.J., Jezorek, I.G., and Prentice, E.F., 2005, Development and use of in-stream PIT-tag detection systems to assess movement behavior of fish in tributaries of the Columbia River Basin, USA, p. 217-220 in Noldus, L.P. J., Grieco, F., Loijens, L.W.S., and Zimmerman, P.H., eds.: Proceedings of the Measuring Behavior 2005, 5th International Conference on Methods and Techniques in Behavioral Research. Noldus Information Technology, Wageningen,The Netherlands.

DeHaan, P., Ardren, W., Gilmore, T., and Werdon, S., 2007, Genetic Analysis of Bull Trout in the Jarbidge River Watershed, Nevada/Idaho draft report: Abernathy Fish Technology Center, Conservation Genetics Program.

Dieterman, D.J., and Hoxmeier, R.J., 2009, Instream evaluation of passive integrated transponder retention in brook trout and brown trout-Effects of season, anatomical placement, and fish length: North American Journal of Fisheries Management, v. 29, p. 109-115.

Donald, D.B., and Alger, D.J., 1993, Geographic distribution, species displacement, and niche Overlap or lake trout and bull trout in mountain lakes: Canadian Journal of Zoology, v. 71, p. 238-247.

Downs, C.C., Horan, D., Morgan-Harris, E., and Jakubowski, R., 2006, Spawning demographics and juvenile dispersal of an adfluvial bull trout population in Trestle Creek, Idaho: North American Journal of Fisheries Management, v. 26, p. 190-200.

Dunham, J.B., and Rieman, B.E., 1999, Metapopulation structure of bull trout: influences of physical, biotic, and geometrical landscape characteristics: Ecological Applications, v. 9, p. 642-655.

Dunham, J.B., Rieman, B.E., and Chandler, G.L., 2003a, Influences of temperature and environmental variables on the distribution of bull trout at the southern margin of its range: North American Journal of Fisheries Management, v. 23, p. 894-904.

Dunham, J.B., Schroeter, R.E., and Rieman, B.E., 2003b, Influence of maximum water temperature on occurrence of Lahontan cutthroat trout within streams: North American Journal of Fisheries Management, v. 23, p. 1042-1049.

Elton, C.S., 1958, The ecology of invasion: John Wiley Sons, New York.

Fraley, J.J., and Shepard, B.B., 1989, Life history, ecology and population status of migratory bull trout (Salvelinus confluentus) in the Flathead Lake and River system: Montana: Northwest Science, v. 63, p. 133-143.

Johnson, G., 2002, Jack Creek bull trout inventory, in Johnson, G., Statewide fisheries management Federal Aid job progress reports F-20-37: Native fishes/amphibian management, Eastern Region, Nevada Division of Wildlife, Elko, Nevada.

Haas, G.R., and McPhail, J.D., 2001, The post-Wisconsinian glacial biogeography of bull trout (Salvelinus confluentus)_A multivariate morphometric approach for conservation biology and management: Canadian Journal of Fisheries and Aquatic Science, v. 58, p. 2189-2203.

Harvey, B.C., White., J.L., and Nakamoto R.J., 2004, An emergent multiple predator effect may enhance biotic resistance in a stream fish assemblage: Ecology, v. 85, p. 127-133.

Hawkins, C.P., Kershner, J.L., Bisson, P.A., Bryant, M.D., Decher, L.M., Gregory, S.V., McCullough, D.A., Overton, C.K., Reeves, G.H., Steedman, R.J., and Young, M.K., 1993, A hierarchical approach to classifying stream habitat features: Fisheries, v. 18, p. 3-12. 
Homel, K., and Budy, P., 2008, Temporal and spatial variability in the migration patterns of juvenile and subadult bull trout in Northeastern Oregon: Transactions of the American Fisheries Society, v. 137, p. 869-880.

Hughes, N.F., 1998, A model of habitat selection by drift-feeding stream salmonids at different scales: Ecology, v. 79, p. 281-294.

McPhail, J.D., and Murray, C.B., 1979, The early life history and ecology of Dolly Varden (Salvelinus malma) in the upper Arrow Lakes: Unpublished report to the British Columbia Hydro and Power Authority and the Fish and Wildlife Branch, Kootenay Region, Cranbrook, British Columbia.

Mesa, M.G., Weiland, L.K., and Zydlewski, G.B., 2004, Critical swimming speeds of wild bull trout: Northwest Science, v. 78, p. 59-65.

Mogen, J.T., and Kaeding, L.R., 2005, Identification and characterization of migratory and nonmigratory bull trout populations in the St. Mary River drainage, Montana: Transactions of the American Fisheries Society, v. 135, p. 841-852

Monnot, L., Dunham, J.B., Hoem, T., and Koetsier P., 2008, Influences of body size and environment factors on autumn downstream migration of bull trout in the Boise River, Idaho: North American Journal of Fisheries Management, v. 28, p. 231-240.

Muhlfeld, C.C., Glutting, S., Hunt, R., Daniels, D., and Marotz, B., 2003, Winter diel habitat use and movement by subadult bull trout in the upper Flathead River, Montana: North American Journal of Fisheries Management, v. 23, p. 163-171.

Muhlfeld, C.C., and Marotz, B., 2005, Seasonal movement and habitat use by subadult bull trout in the upper Flathead River system: North American Journal of Fisheries Management, v. 25, p. 797-810.

Patrick, R., 1975, Structure of stream communities, in Cody, M.L., and Diamond, J.M., eds.: Ecology and evolution of communities: The Belknap Press of Harvard University Press, Cambridge, Mass., p.445-459

Paul, A.J., and Post, J.R., 2001, Spatial distribution of native and nonnative salmonids in streams of the eastern slopes of the Canadian Rocky Mountains: Transactions of the American Fisheries Society, v. 130, p. 417-430.

Ratliff, D.E., 1992, Bull trout investigations in the Metolius River-Lake Billy Chinook System, in Howell, P.J., and Buchanan, D.V., eds., Proceedings of the Gearhart Mountain Bull Trout Workshop: American Fisheries Society, Oregon Chapter, Corvallis, Oreg., p. 37-44.

Reynolds, J.B., 1983, Electrofishing, in Nielson, L.A., and Johnson, D.L., eds., Fisheries techniques: American Fisheries Society, Bethesda, Md., p. 147-163

Rieman, B.E., and McIntyre, J.D., 1993, Demographic and habitat requirements for conservation of bull trout: U.S. Forest Service General Technical Report INT-308.

Rieman, B.E., Isaak, D., Adams, S., Horan, D., Nagel, D., Luce, C., and Myers D., 2007, Anticipated climate warming effects on bull trout habitats and populations across the interior Columbia River basin: Transactions of the American Fisheries Society, v. 136, p. 1552-1567.

Ripley, T., Scrimgeour, G., and Boyce, M.S., 2005, Bull trout occurrence and abundance influenced by cumulative industrial developments in a Canadian boreal forest watershed: Canadian Journal of Fisheries and Aquatic Sciences, v. 62, p. 2431-2442.

Schlosser, I.J., 1982, Fish community structure and function along two habitat gradients in a headwater stream: Ecological Monographs, v. 52, p. 395-414.

Seber, G.A.F., 1982, The estimation of animal abundance and related parameters, 2nd ed.: Macmillan Publishing Company, Inc. New York. 
Stelfox, J.D., 1997, Seasonal movements, growth, survival and population status of the adfluvial bull trout population in lower Kananaskis Lake, Alberta, in Mackay, W.C., Brewin, M.K., and Monita, M., eds., Friends of the Bull Trout conference Proceedings: Bull Trout Task Force (Alberta), c/o Trout Unlimited Canada, Calgary, p. 309-316

Swanberg, T., 1997, Movements of and habitat use of fluvial bull trout in the Blackfoot River, Montana: Transactions of the American Fisheries Society, v. 126, p. 735-746.

U.S. Fish and Wildlife Service, 2004, Draft Recovery Plan for the Jarbidge River Distinct Population Segment of Bull Trout (Salvelinus confluentus): U.S. Fish and Wildlife Service, Portland, Oreg.

Ward, D.M., Winslow, K.H., and Folt, C.L., 2008, Do native species limit survival of reintroduced Atlantic salmon in historic rearing streams?: Biological Conservation, v. 141, p. 146-152.

Zalewski, M., and Cowx, I.G., 1990, Factors affecting the efficiency of electric fishing, in Cowx and Lamarque, P., eds., Fishing with electricity: Fishing News Books, Oxford, UK., p. 89-110. 


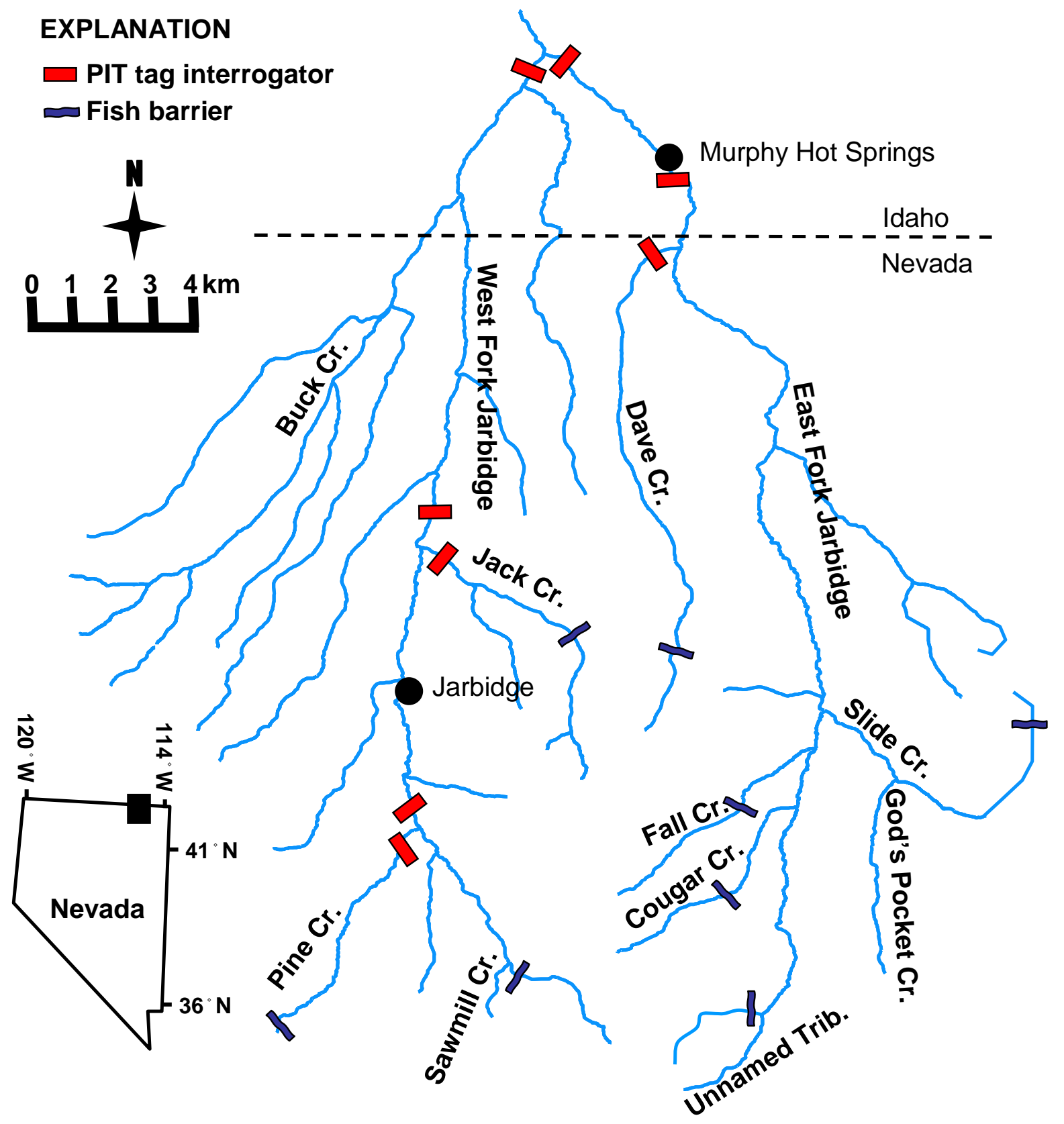

Figure 1. Map of the East and West Forks of the Jarbidge River, Idaho and Nevada, with the locations of reported fish barriers and passive integrated transponder (PIT) tag interrogations systems installed in 2006 or 2007. 


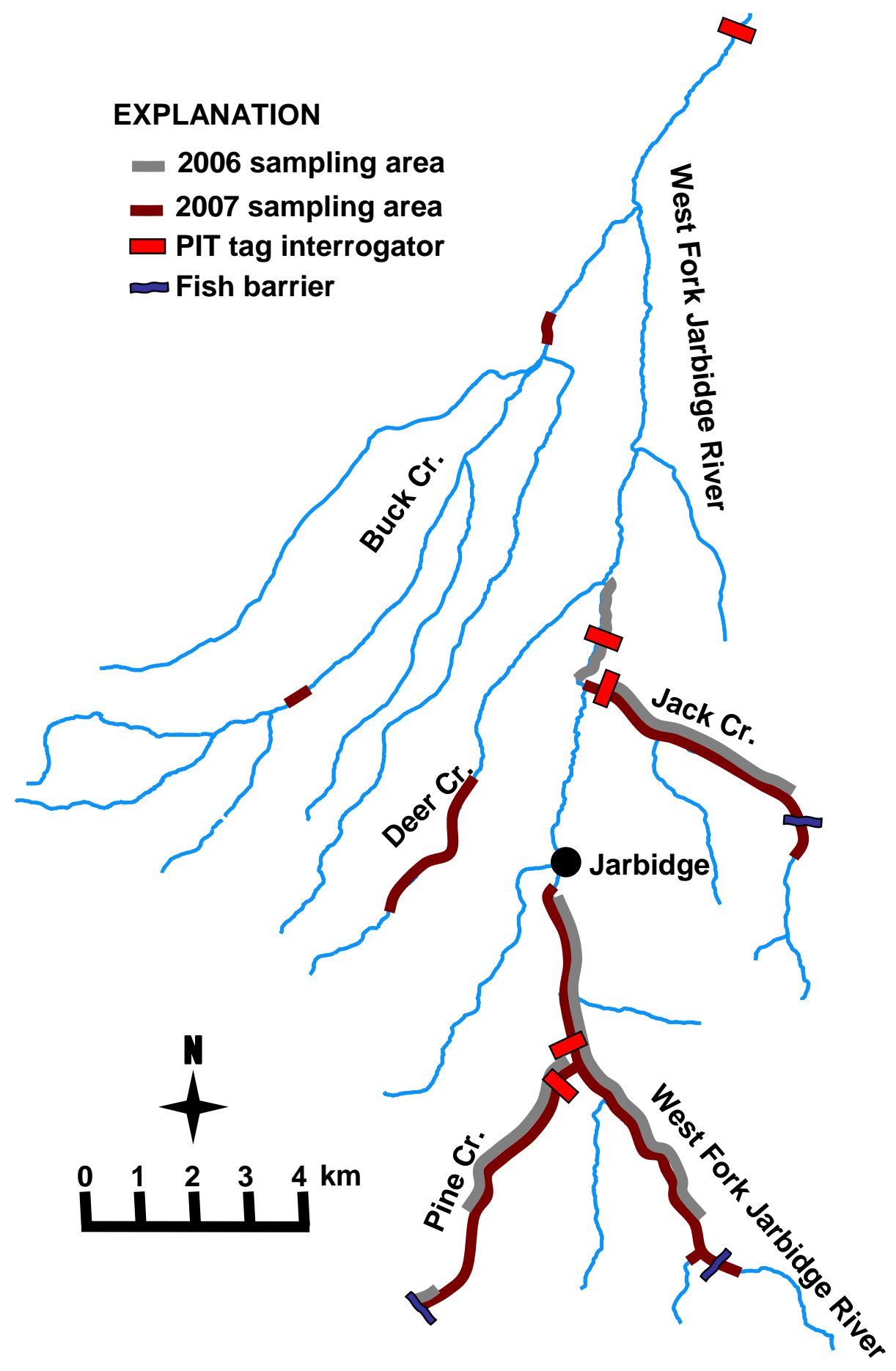

Figure 2. Locations of fish and habitat surveys, fish barriers, and passive integrated transponder (PIT) tag interrogation systems in the West Fork Jarbidge River, Nevada, and its tributaries, 2006 and 2007. The interrogation systems at the confluence of Pine Creek and West Fork Jarbidge River, Nevada, and at the confluence of the East Fork and West Fork Jarbidge River, Idaho, were not installed until 2007. 


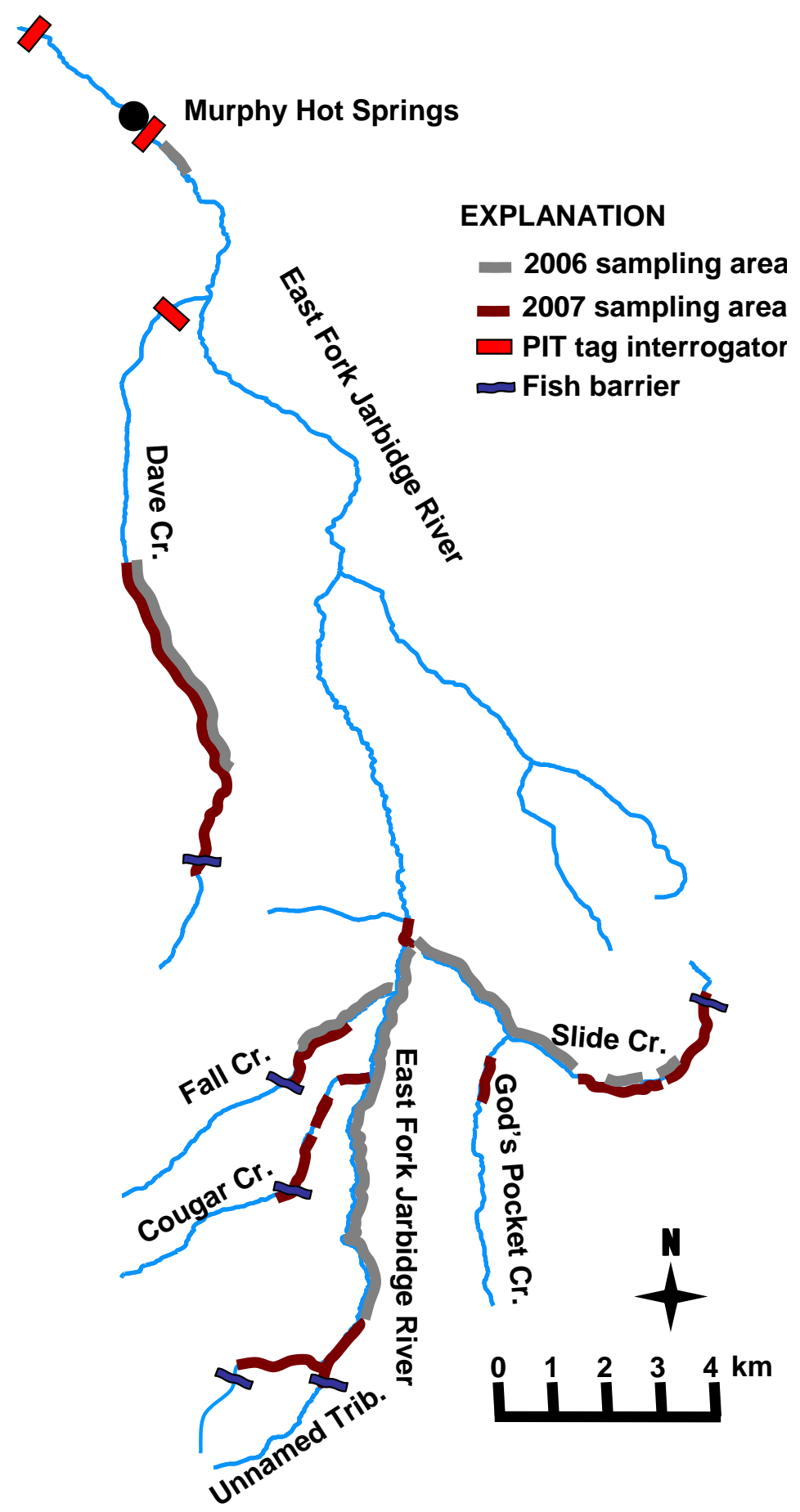

Figure 3. Locations of fish and habitat surveys, fish barriers, and passive integrated transponder (PIT) tag interrogation systems in the East Fork Jarbidge River, Nevada, and its tributaries, 2006 and 2007. The interrogation systems on Dave Creek, Nevada, and at the confluence of the East Fork and West Fork Jarbidge River, Idaho, were not installed until 2007. 

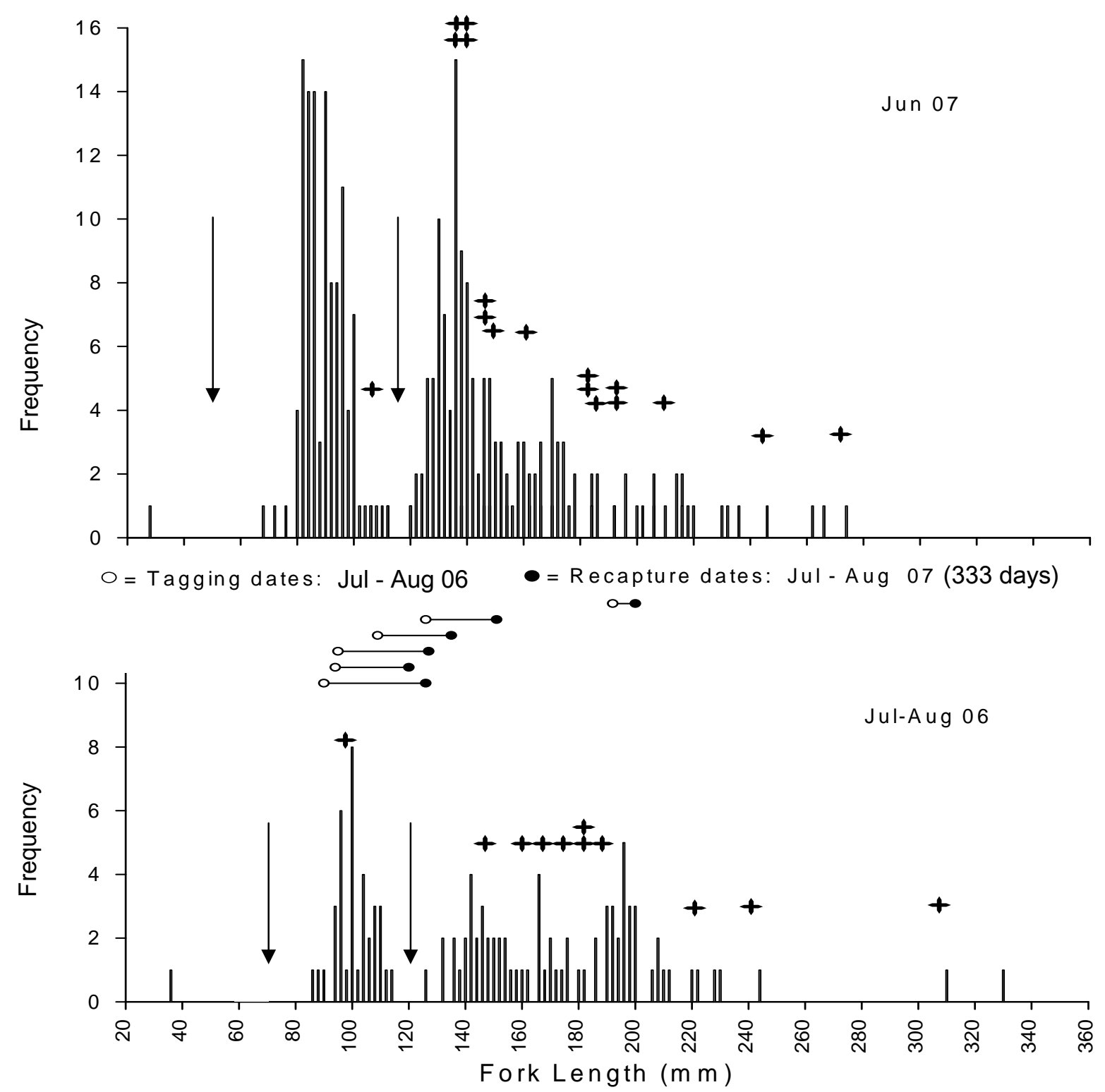

Figure 4. Length frequency, in 2-mm increments, of all bull trout sampled in the West Fork Jarbidge River, Nevada, in 2006 and 2007. The horizontal lines indicate the growth of individual fish that were tagged in 2006 and recaptured in 2007. The median number of days between tagging and recapture are shown in parentheses. Sampling effort is not the same for each year. The symbol " + " indicates the fork length of fish at tagging that were detected at an interrogation site after tagging. Vertical arrows indicate the break between age-0, age-1, and age-2 or older bull trout. 


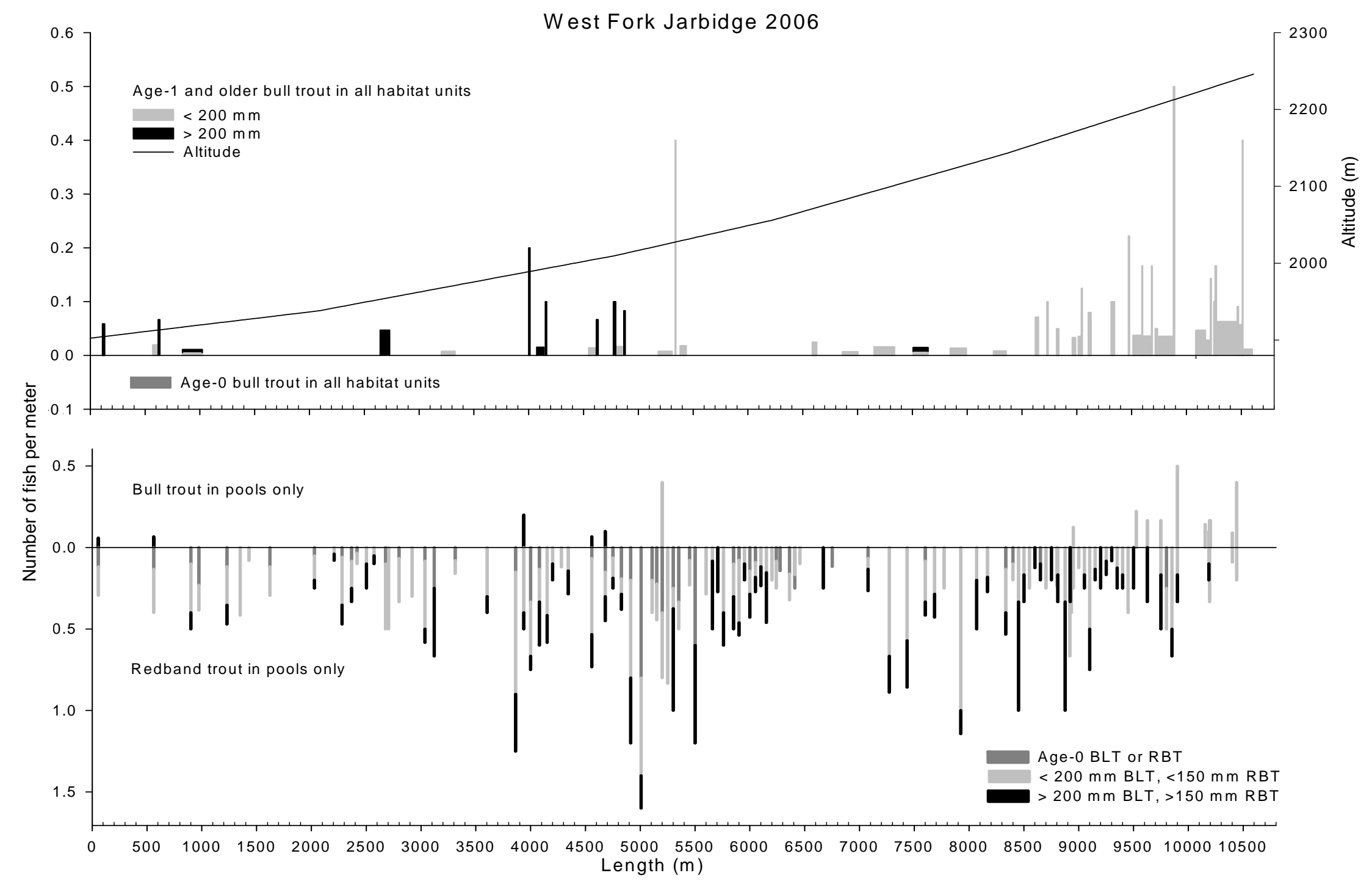

Figure 5. Number of bull trout (BLT) per meter by size class for all habitat units sampled along with altitude (upper graph) and the number of bull trout and redband trout (RBT) per meter by size class in pools only (lower graph) in West Fork Jarbidge River (rkm 21.5 - 30.2), Nevada, 2006. 


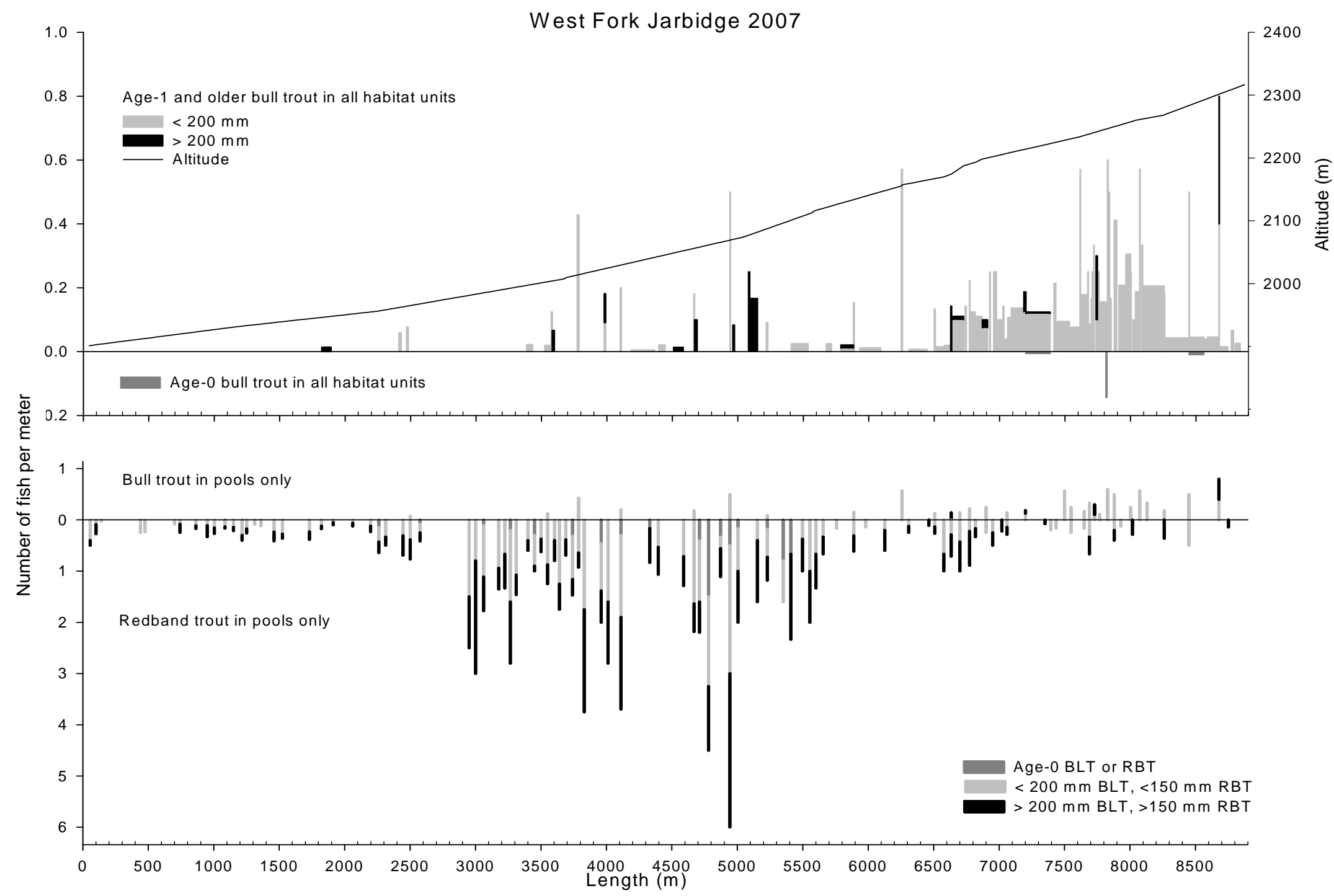

Figure 6. Number of bull trout (BLT) per meter by size class for all habitat units sampled along with altitude (upper graph) and the number of bull trout and redband trout (RBT) per meter by size class in pools only (lower graph) in West Fork Jarbidge River (rkm 21.7 - 32.2), Nevada, 2007. 

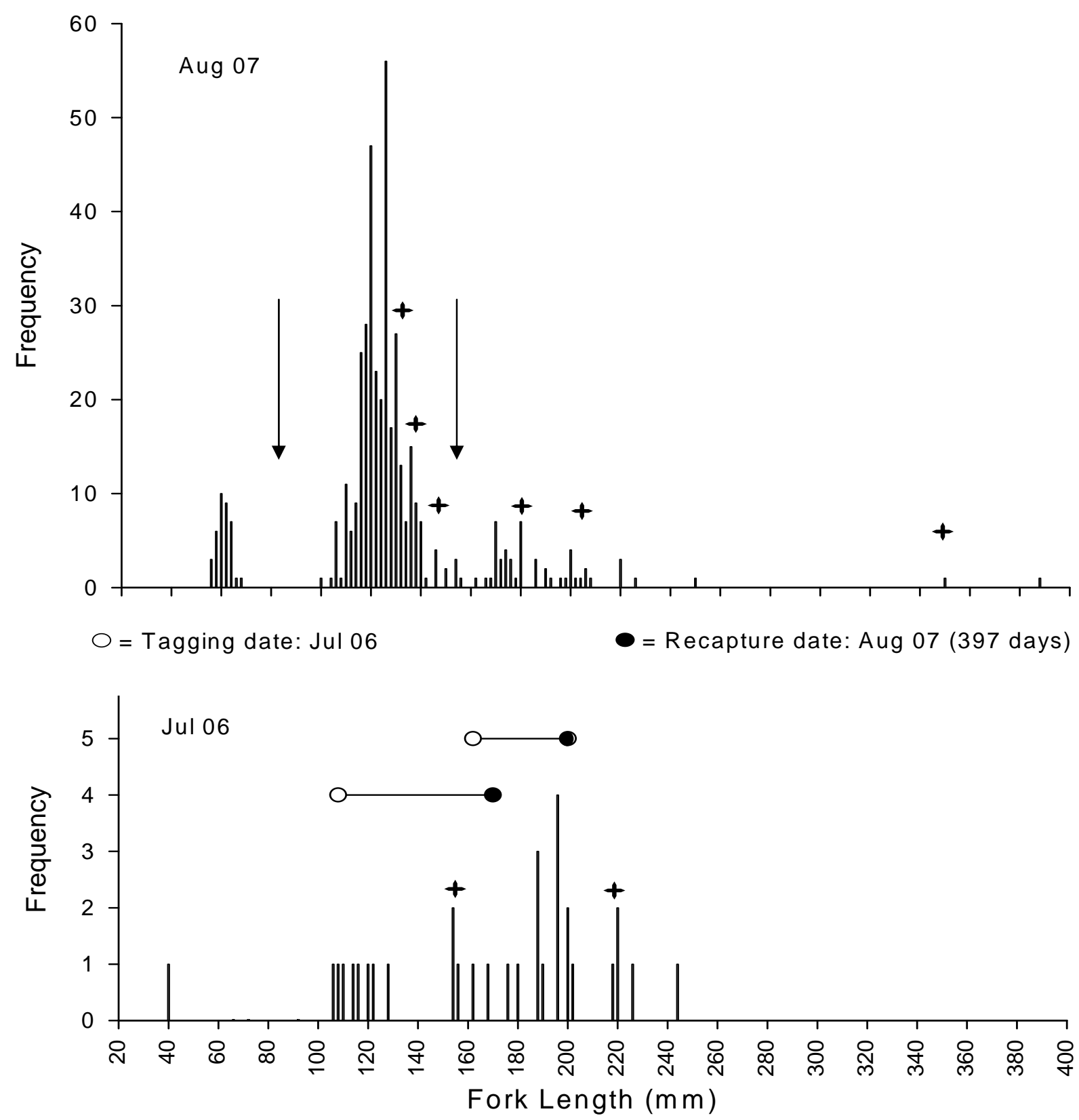

Figure 7. Length frequency ,in 2-mm increments, of all bull trout sampled in Pine Creek of the West Fork Jarbidge River subbasin, Nevada in 2006 and 2007. The horizontal lines indicate the growth of individual fish that were tagged in 2006 and recaptured in 2007. The mean number of days between tagging and recapture are shown in parentheses. The symbol "+" indicates the fork length of fish at tagging that were detected at an interrogation site after tagging. Vertical arrows indicate the break between age-0, age-1, or age-2 or older bull trout. 


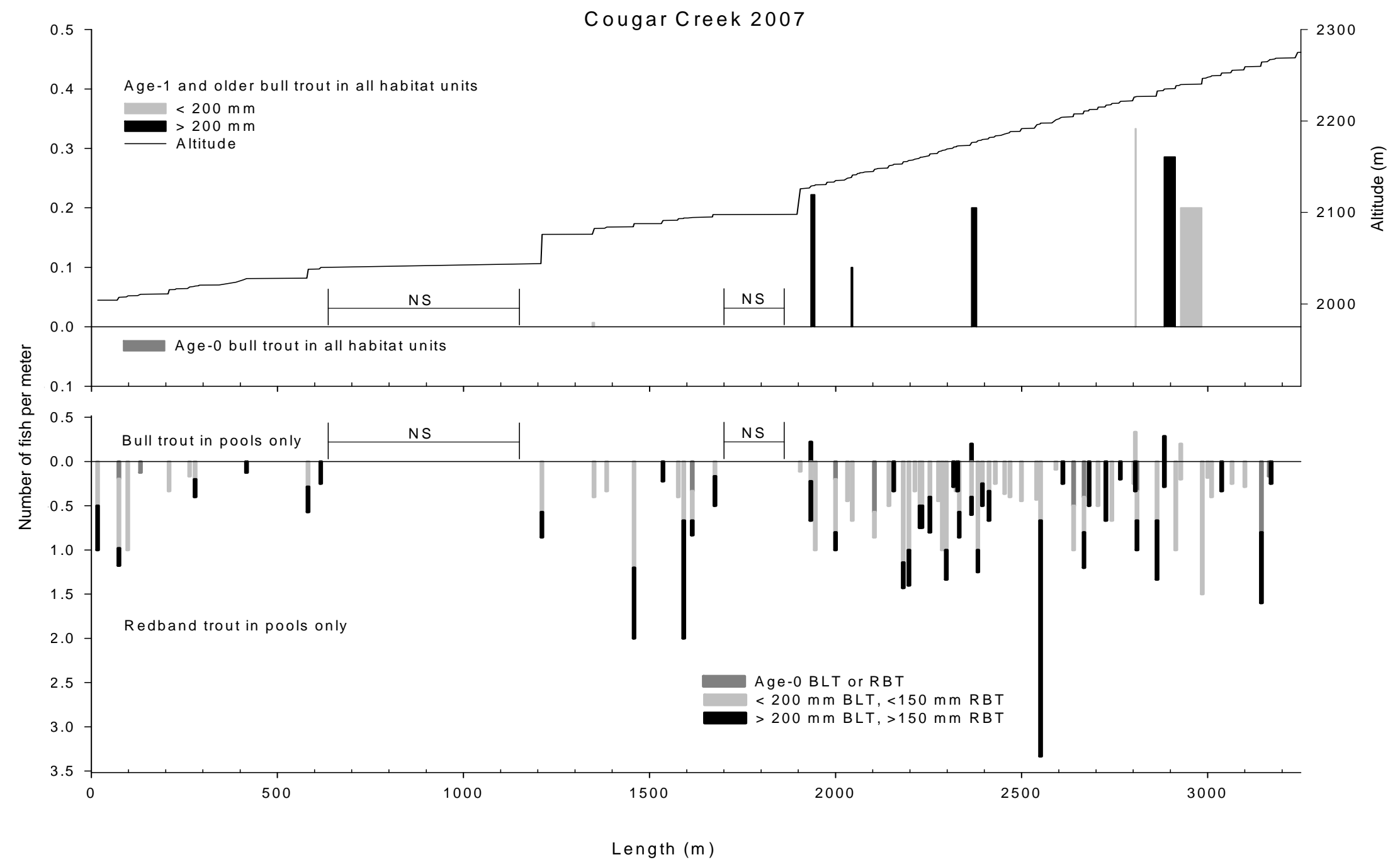

Figure 8. Number of bull trout (BLT) per meter by size class for all habitat units sampled along with altitude (upper graph) and the number of bull trout and redband trout (RBT) per meter by size class in pools only (lower graph) in Pine Creek (rkm 0-6.5), Nevada, 2006. NS = not sampled. 


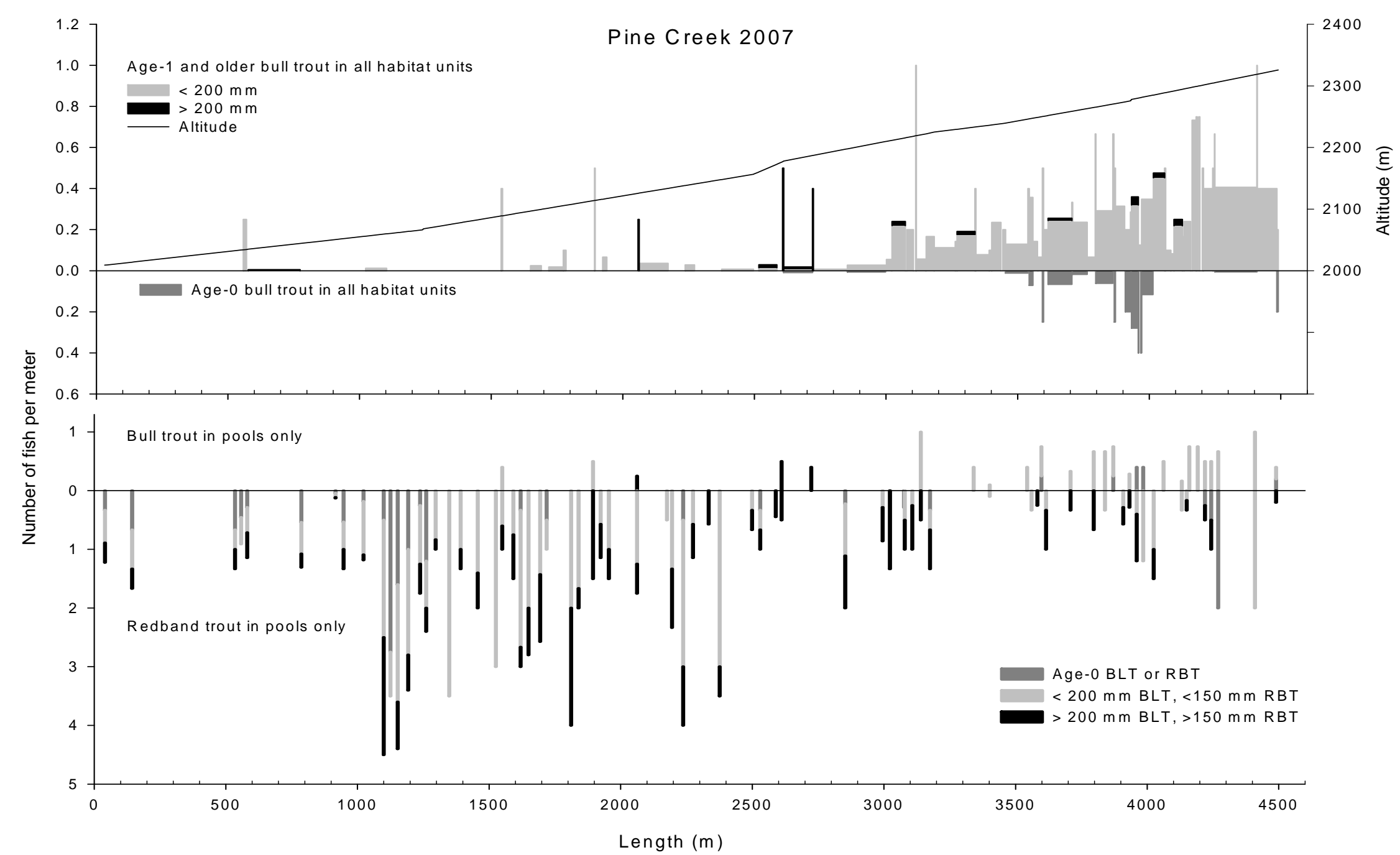

Figure 9. Number of bull trout (BLT) per meter by size class for all habitat units sampled along with altitude (upper graph) and the number of bull trout and redband trout (RBT) per meter by size class in pools only (lower graph) in Pine Creek (rkm 0 - 5.9), Nevada, 2007. 

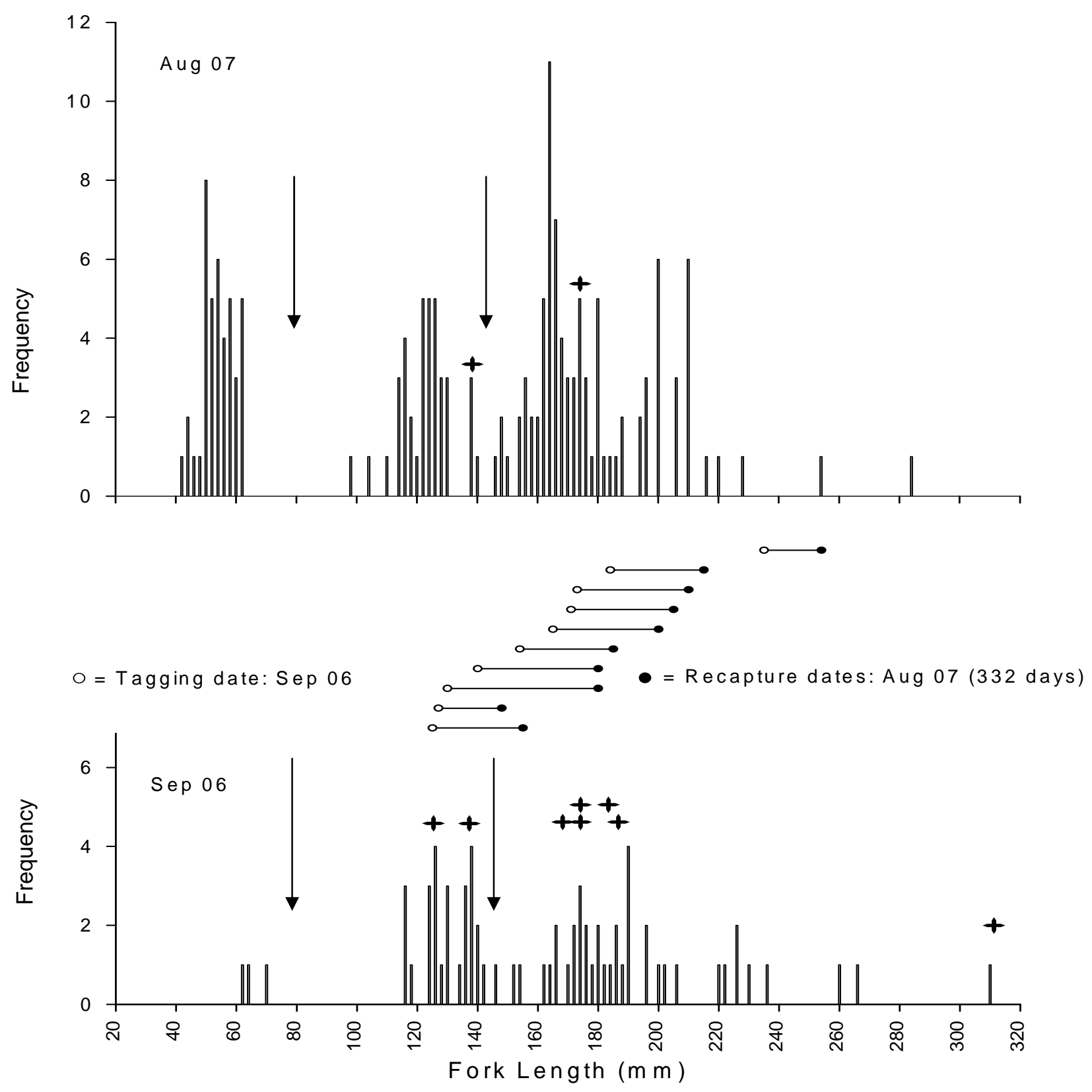

Figure 10. Length frequency in 2-mm increments of all bull trout sampled in Jack Creek of the West Fork Jarbidge River, Nevada, in 2006 and 2007. The horizontal lines indicate the growth of individual fish that were tagged in 2006 and recaptured in 2007. The number of days between tagging and recapture are shown in parentheses. The symbol " + " indicates the fork length of fish at tagging that were detected at an interrogation site after tagging. Vertical arrows indicate the break between age-0, age-1, and age-2 or older bull trout 


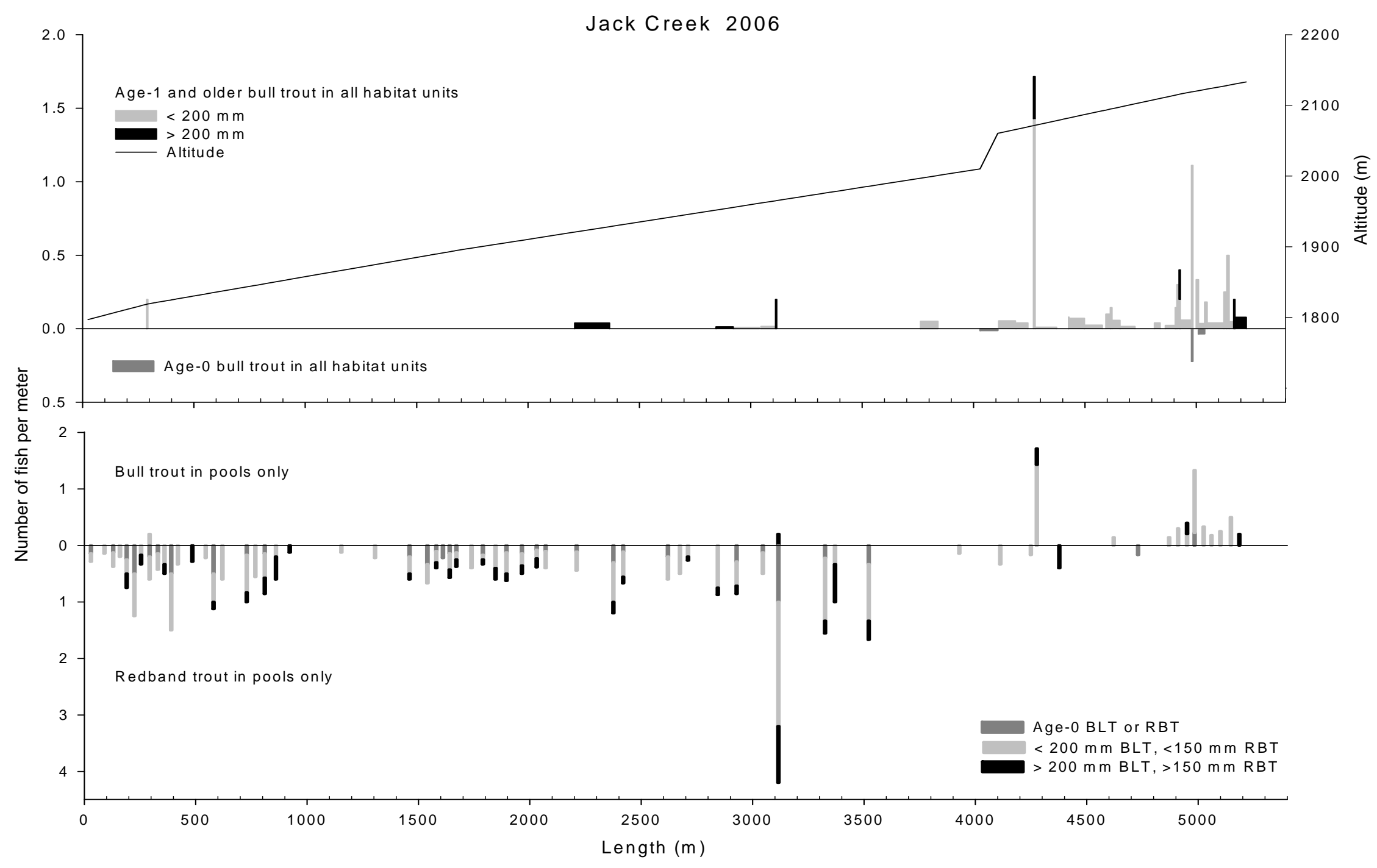

Figure 11 Number of bull trout (BLT) per meter by size class for all habitat units sampled along with altitude (upper graph) and the number of bull trout and redband trout (RBT) per meter by size class in pools only (lower graph) in Jack Creek (rkm 0 - 4.3), Nevada, 2006. 


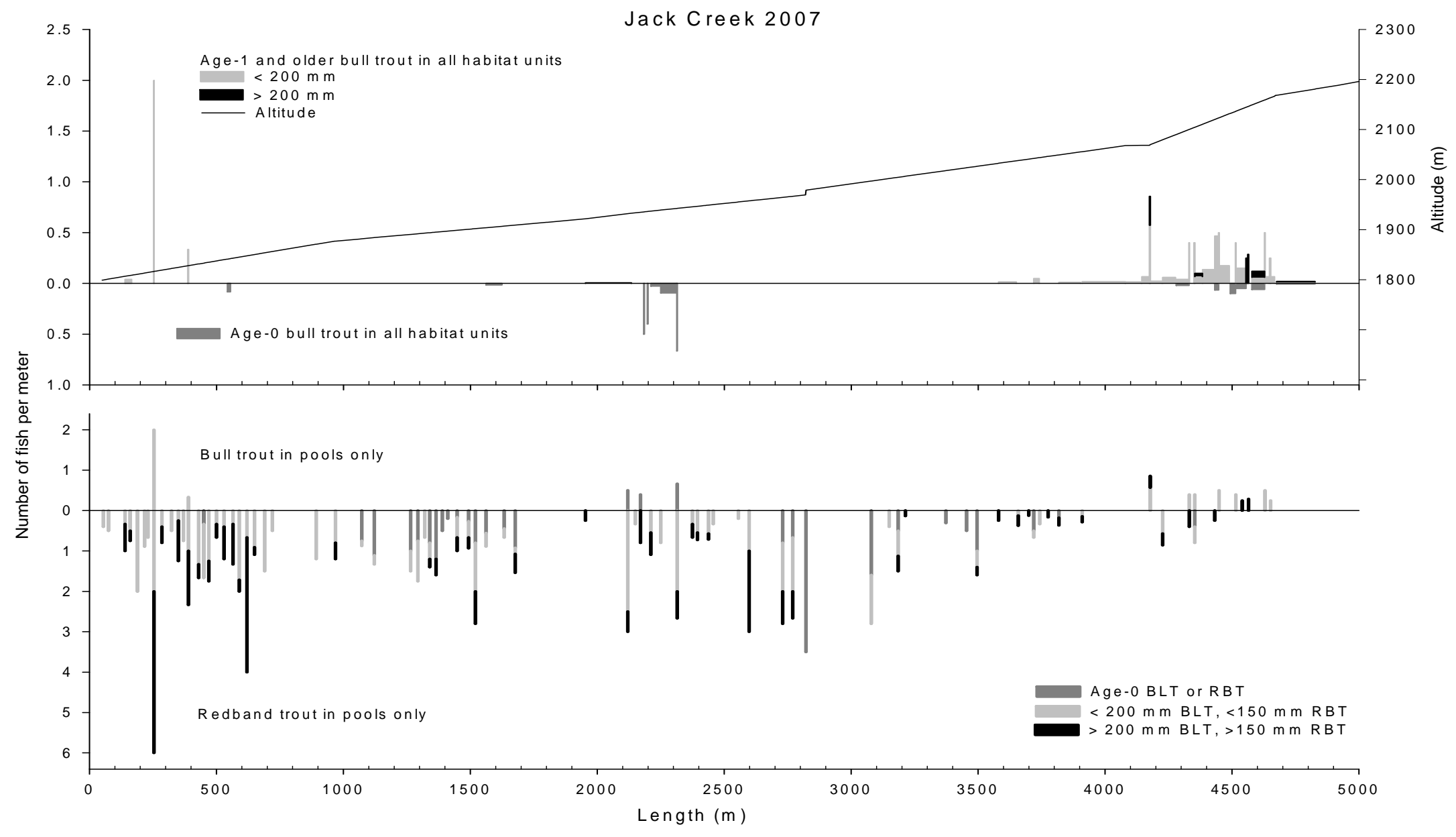

Figure 12. Number of bull trout (BLT) per meter, by size class, for all habitat units sampled along with altitude (upper graph) and the number of bull trout and redband trout (RBT) per meter by size class in pools only (lower graph) in Jack Creek (rkm 0 - 5.4), Nevada, 2007. 

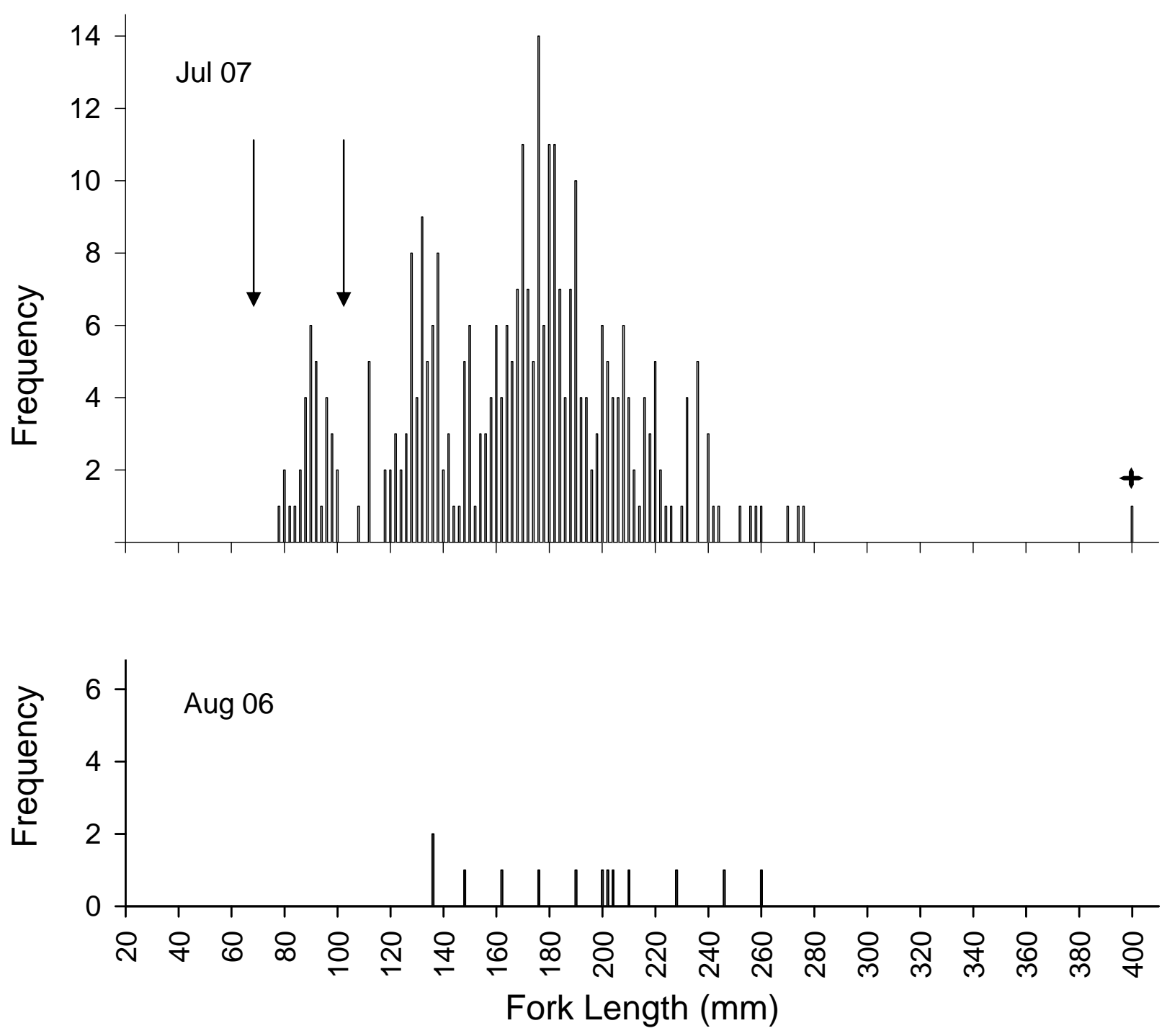

Figure 13. Length frequency in 2-mm increments of all bull trout sampled in the East Fork Jarbidge River, Nevada, in 2006 and 2007. Sampling effort is not the same for each year. Vertical arrows indicate the break between age-0, age-1, and age-2 or older bull trout. The symbol "+" indicates the fork length of a fish that was recaptured in the East Fork Jarbidge River after being tagged in Fall Creek in 2006. 


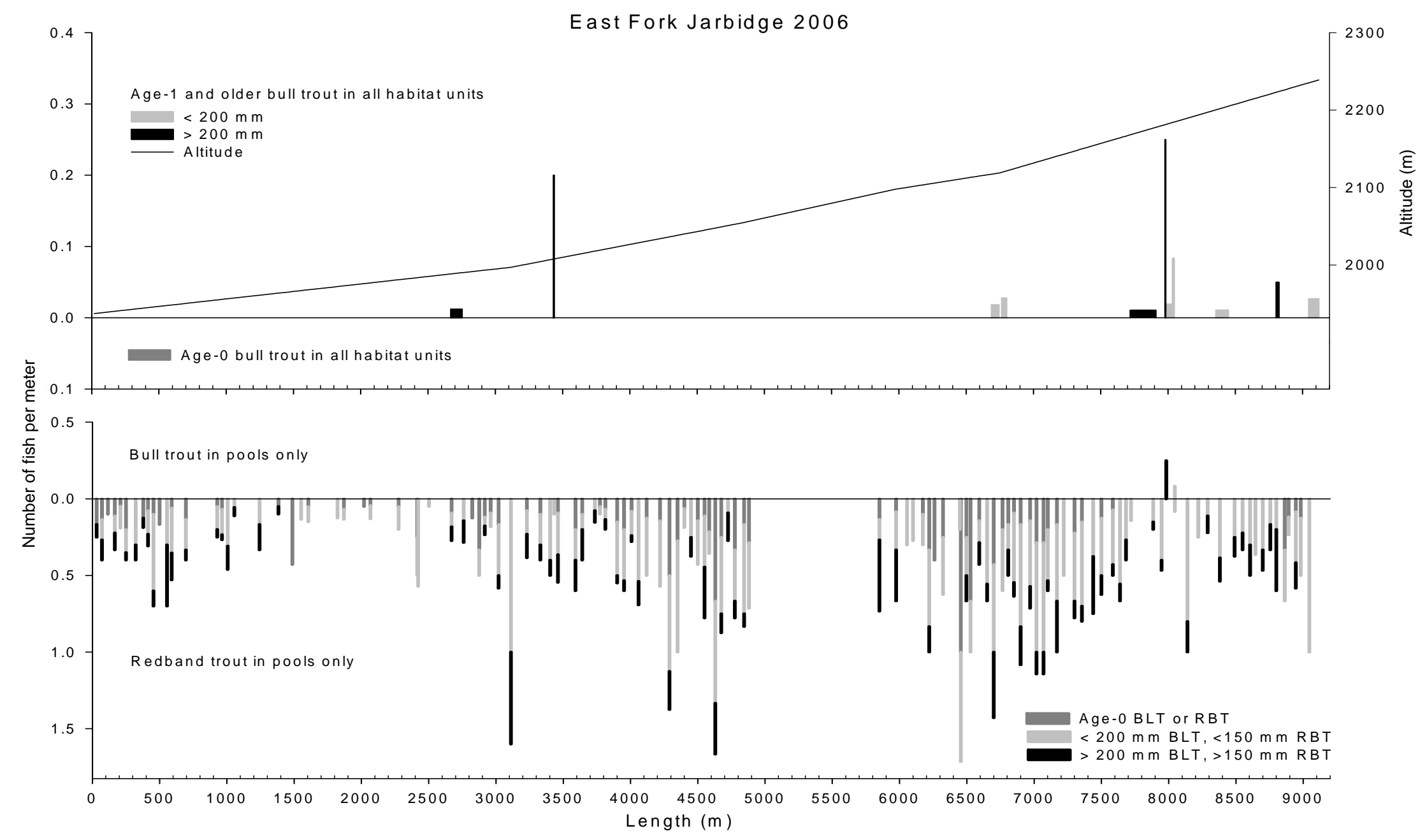

Figure 14. Number of bull trout (BLT) per meter by size class for all habitat units sampled along with altitude (upper graph) and the number of bull trout and redband trout (RBT) per meter by size class in pools only (lower graph) in East Fork Jarbidge River (rkm 15.6 - 24.7), Nevada, 2006. NS = not sampled. 


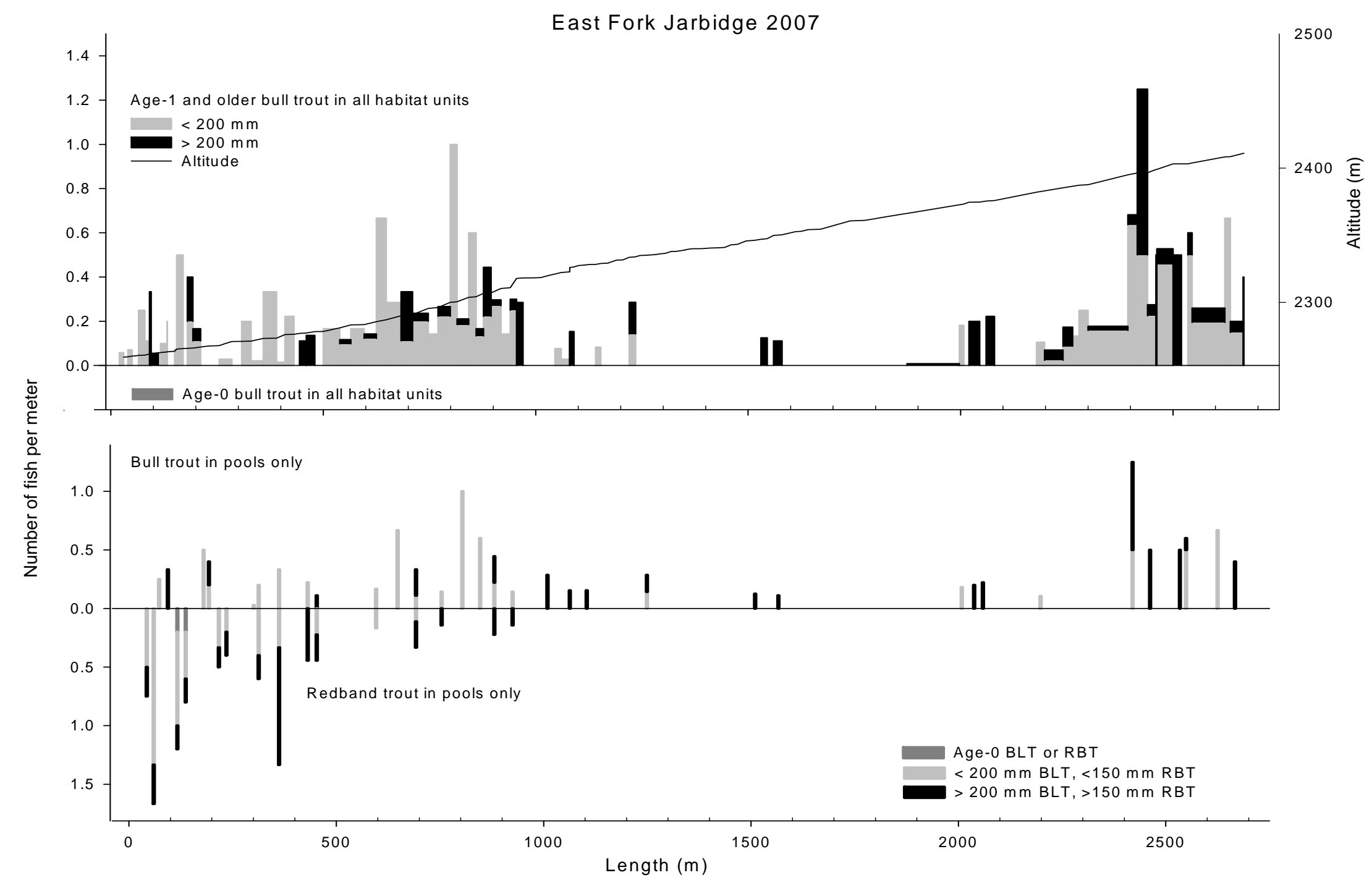

Figure 15. Number of bull trout (BLT) per meter by size class for all habitat units sampled along with altitude (upper graph) and the number of bull trout and redband trout (RBT) per meter by size class in pools only (lower graph) in East Fork Jarbidge River (rkm 32.5 - 35.0), Nevada, 2007. 

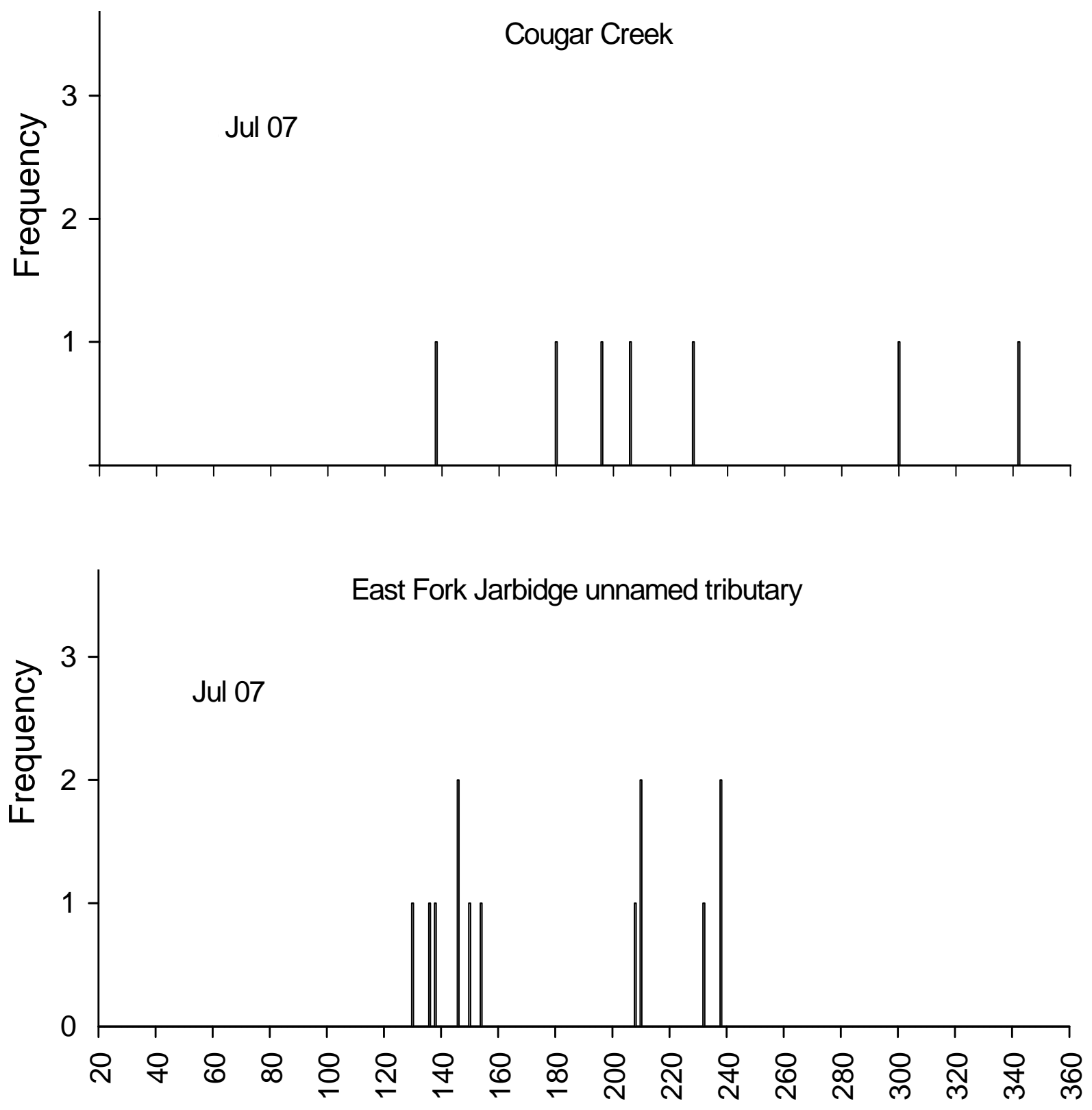

Figure 16. Length frequency in 2-mm increments of all bull trout sampled in Cougar Creek, Nevada, and an unnamed tributary of the East Fork Jarbidge River, Nevada, at rkm 33.5 (measured from the confluence with the West Fork Jarbidge River, Idaho), 2007. 


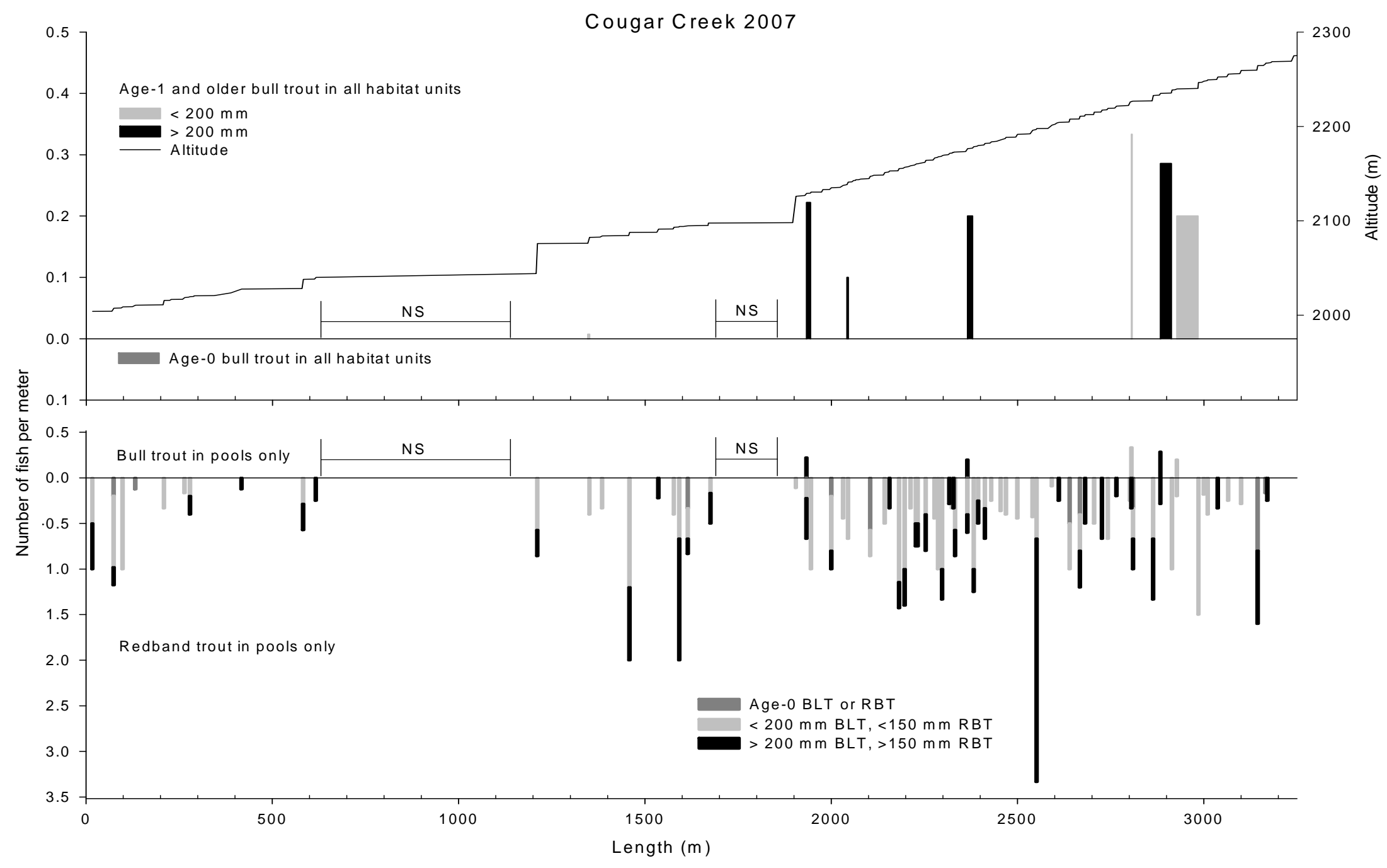

Figure 17. Number of bull trout (BLT) per meter by size class for all habitat units sampled along with altitude (upper graph) and the number of bull trout and redband trout (RBT) per meter by size class in pools only (lower graph) in Cougar Creek (rkm 0 - 3.1), Nevada, 2007. NS = not sampled. 

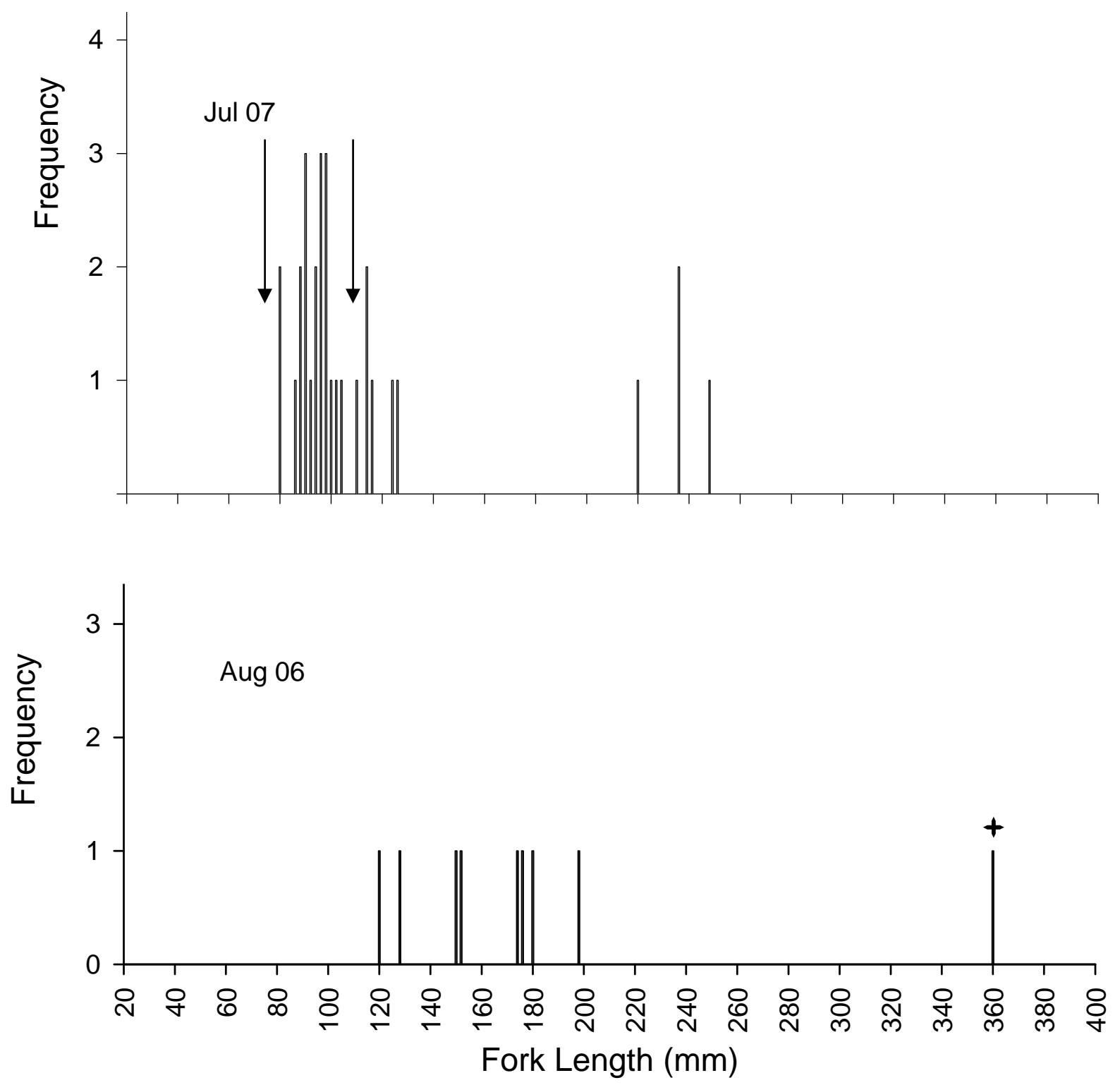

Figure 18. Length frequency in 2-mm increments of all bull trout sampled in Fall Creek of the East Fork Jarbidge River, Nevada, in 2006 and 2007. Sampling effort is not the same for each year. Vertical arrows indicate the break between age-0, age-1, and age-2 or older bull trout. The symbol "t" indicates the fork length of a fish that had moved and subsequently recaptured in the East Fork Jarbidge downstream of the confluence with Slide Creek. 


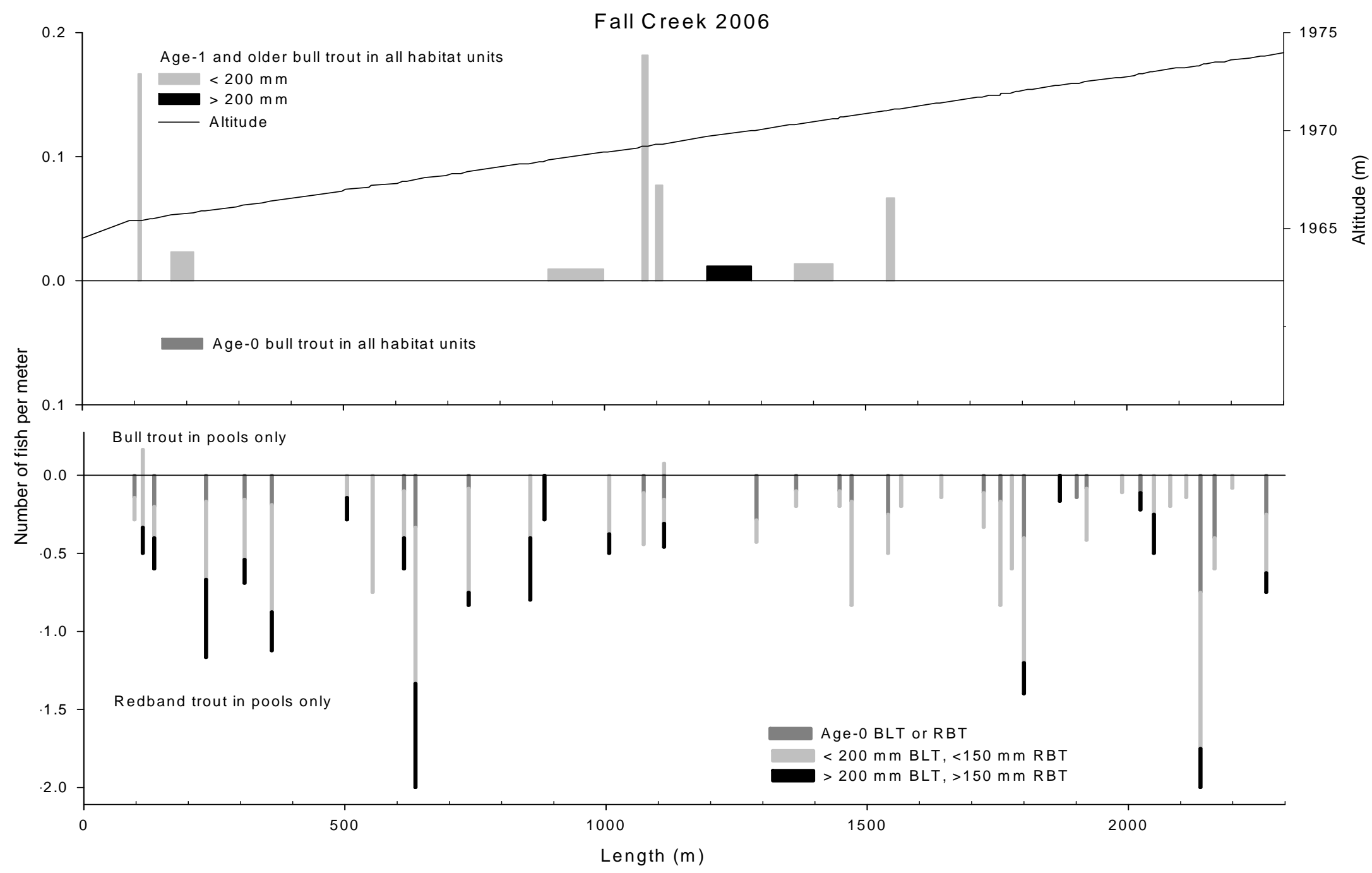

Figure 19. Number of bull trout (BLT) per meter by size class for all habitat units sampled along with altitude (upper graph) and the number of bull trout and redband trout (RBT) per meter by size class in pools only (lower graph) in Fall Creek (rkm O-2.0), Nevada, 2006. 


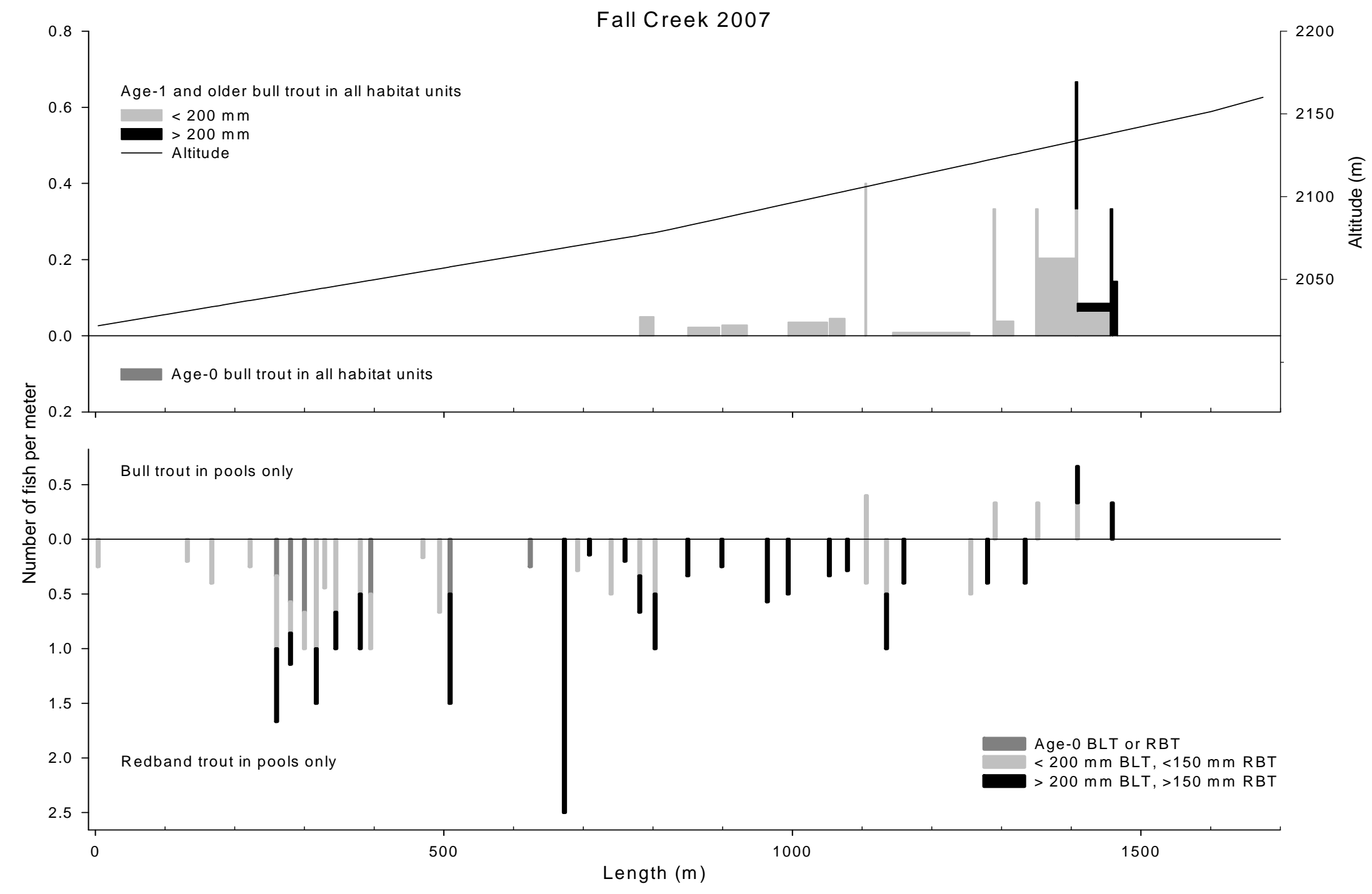

Figure 20. Number of bull trout (BLT) per meter by size class for all habitat units sampled along with altitude (upper graph) and the number of bull trout and redband trout (RBT) per meter by size class in pools only (lower graph) in Fall Creek (rkm 1.4 - 3.2), Nevada, 2007. 

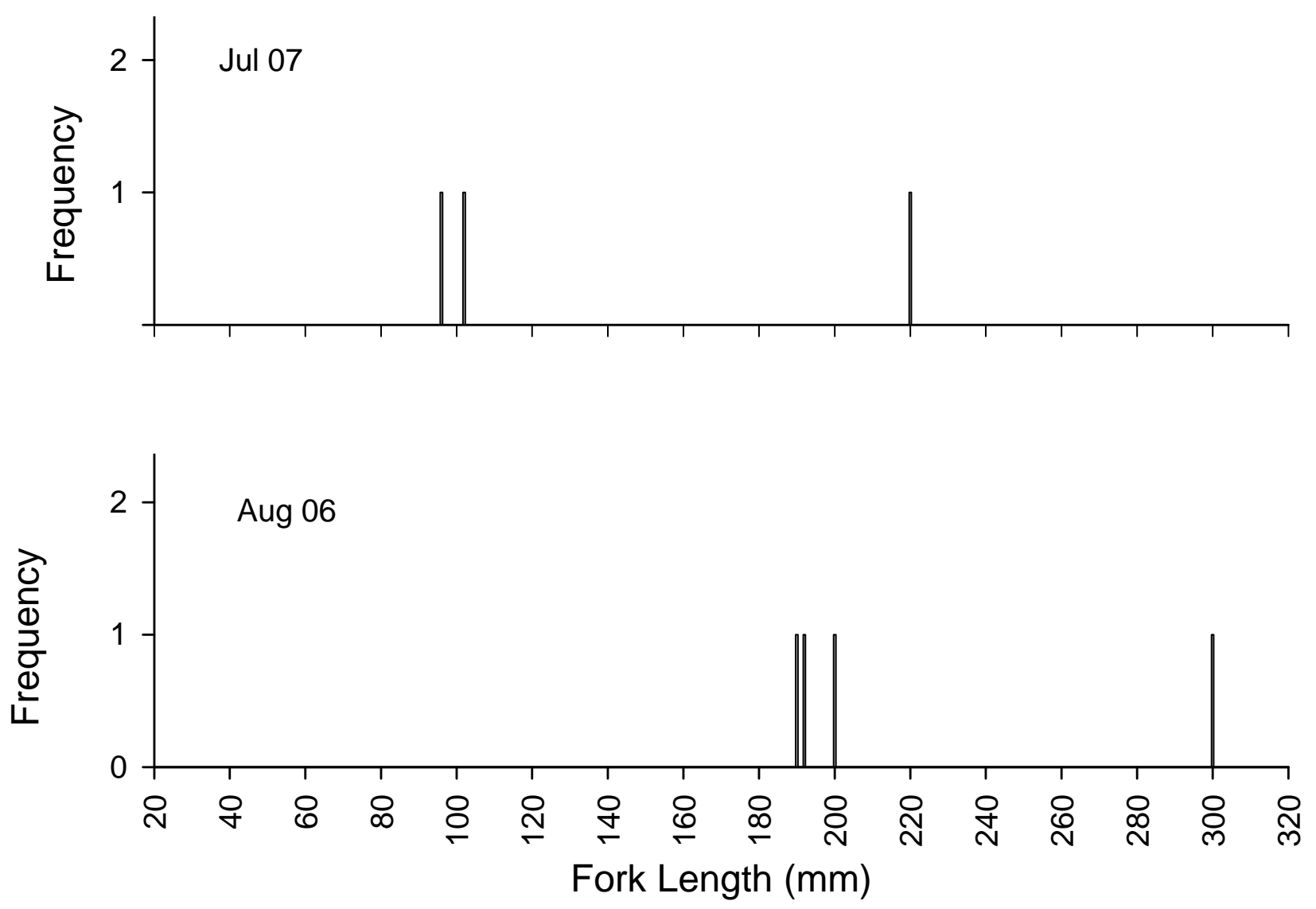

Figure 21. Length frequency in 2-mm increments of all bull trout sampled in Slide Creek of the East Fork Jarbidge River, Nevada, in 2006 and 2007. Sampling effort is not the same for each year. 


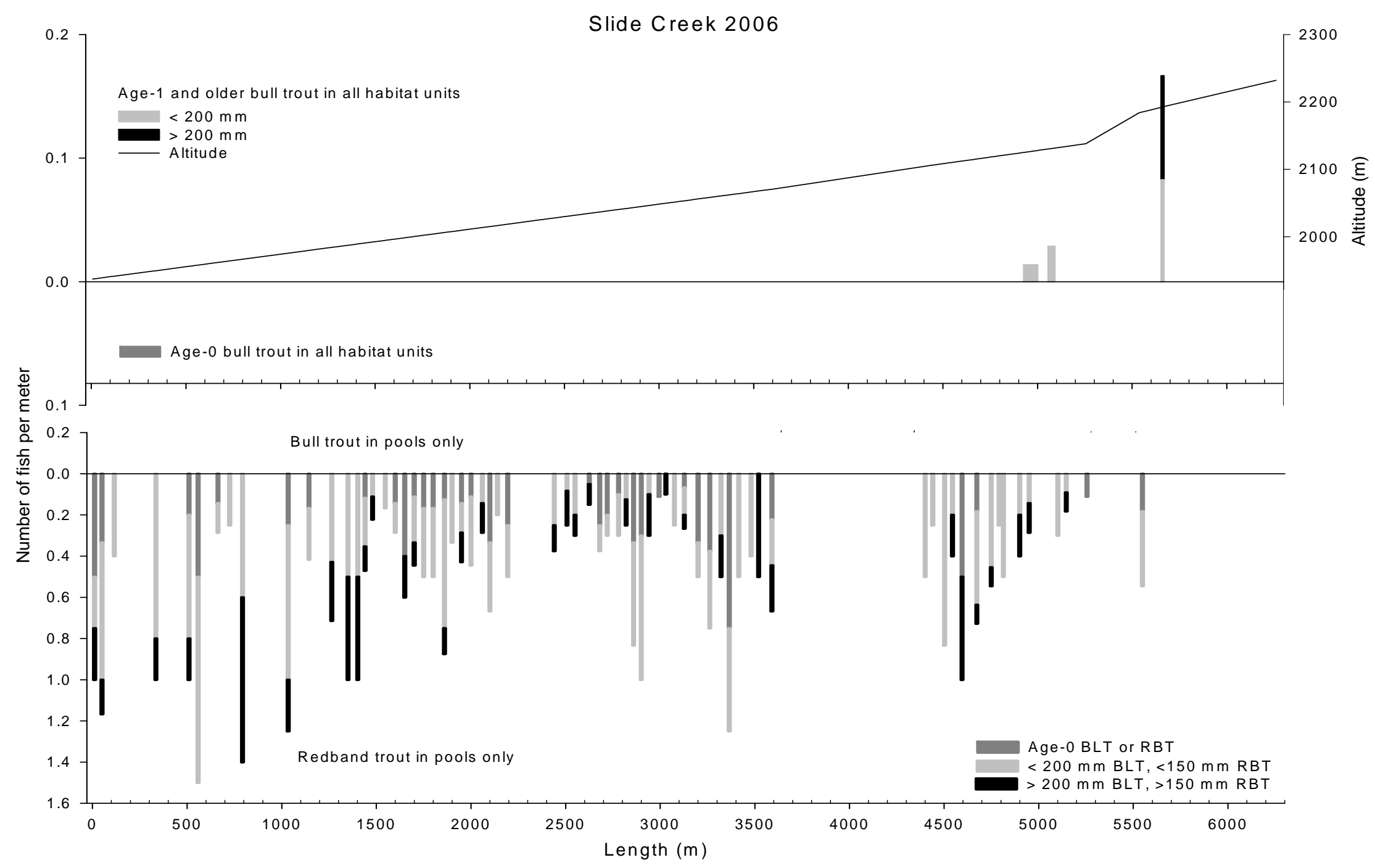

Figure 22. Number of bull trout (BLT) per meter by size class for all habitat units sampled along with altitude (upper graph) and the number of bull trout and redband trout (RBT) per meter by size class in pools only (lower graph) in Slide Creek (rkm 0 - 5.5), Nevada, 2006. NS = not sampled. 


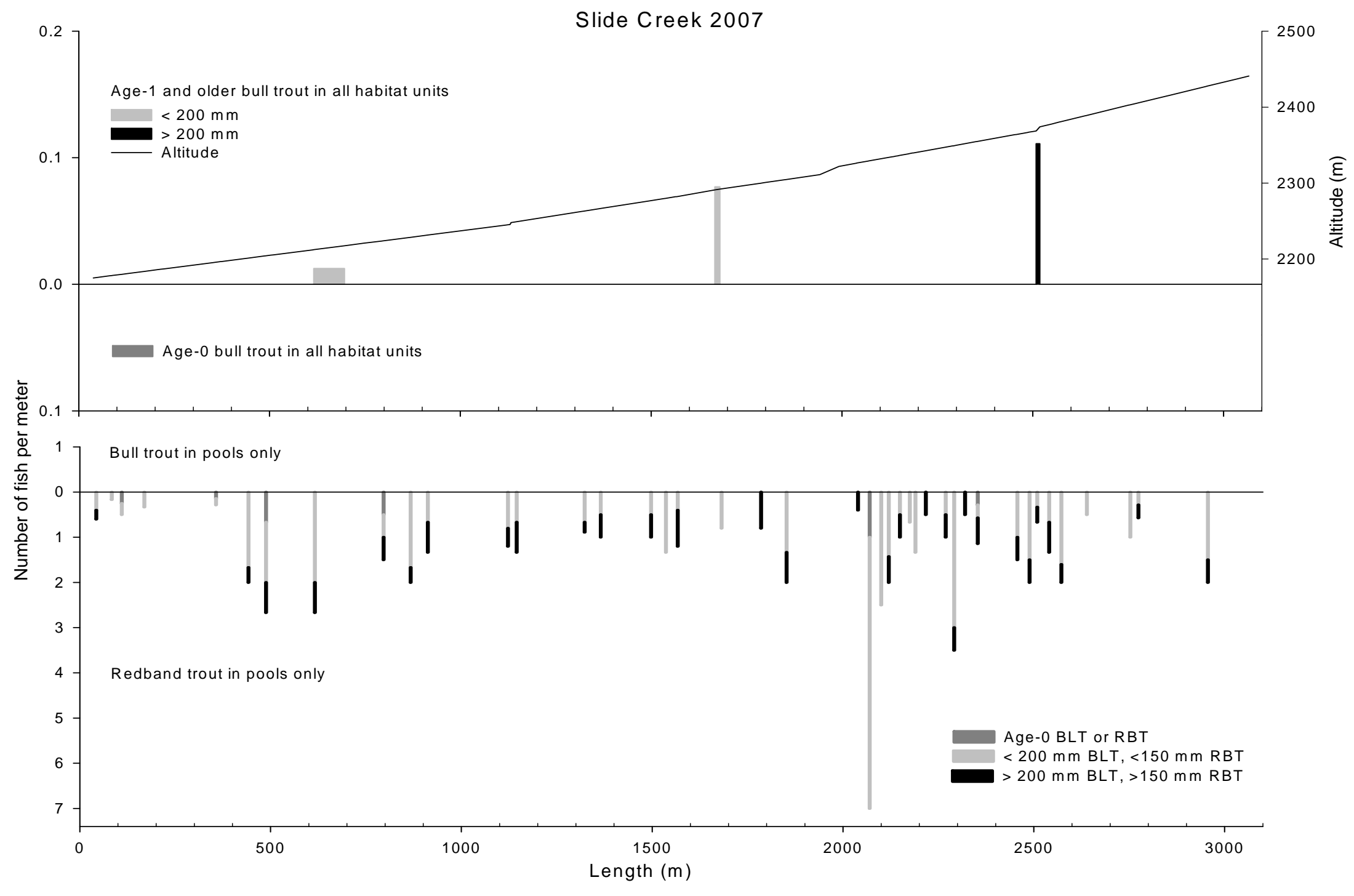

Figure 23. Number of bull trout (BLT) per meter by size class for all habitat units sampled along with altitude (upper graph) and the number of bull trout and redband trout (RBT) per meter by size class in pools only (lower graph) in Slide Creek ( $\mathrm{rkm} 4.6-7.7)$, Nevada, 2007. NS= not sampled. 

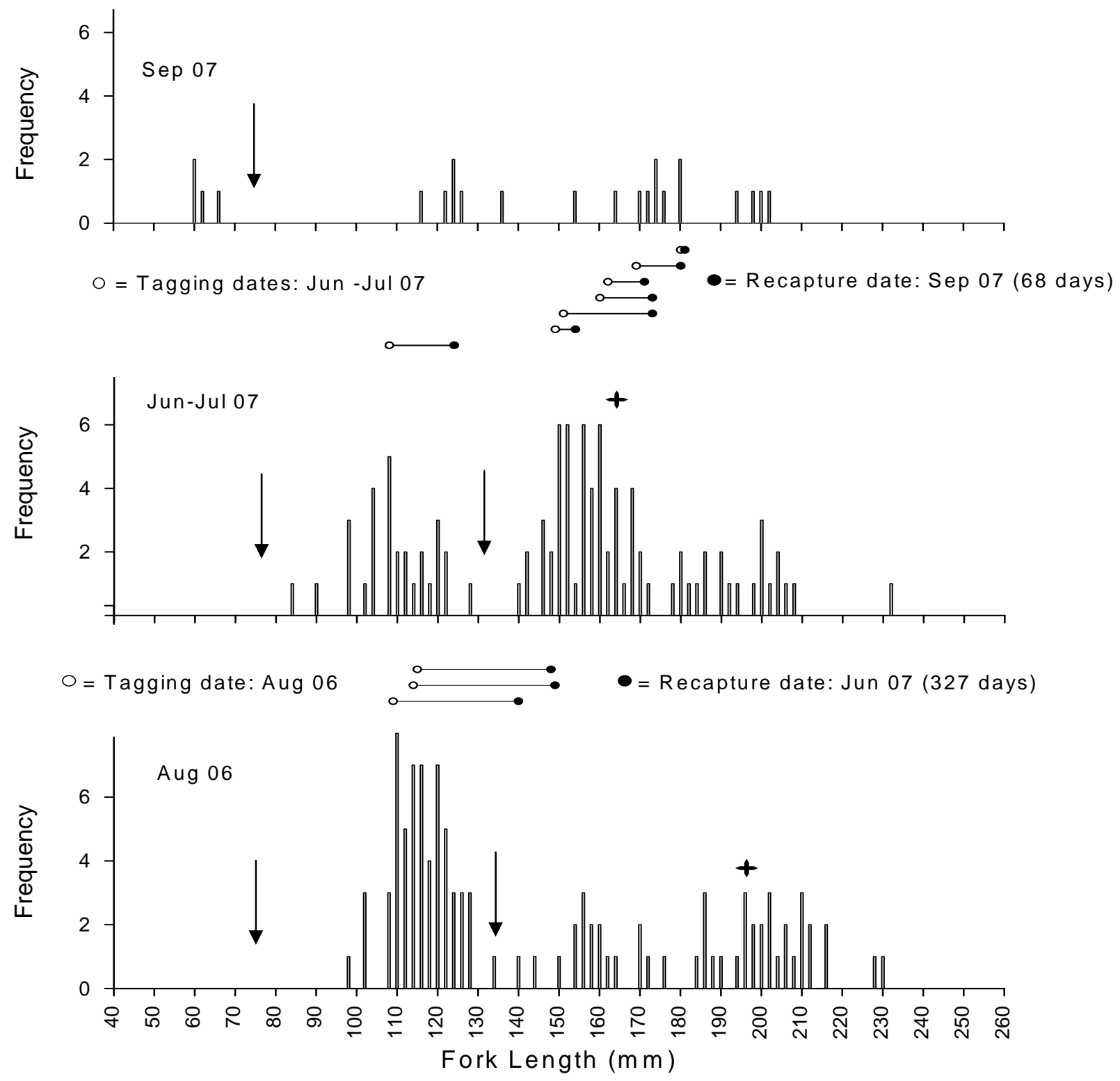

Figure 24. Length frequency in 2-mm increments of all bull trout sampled in Dave Creek of the East Fork Jarbidge River, Nevada, in summer 2006, early summer 2007, and late summer 2007. The horizontal lines indicate the growth of individual fish that were tagged in 2006 and recaptured in early summer 2007, and those that were tagged early summer 2007 and recaptured late summer 2007. The number of days between tagging and recapture are shown in parentheses. The symbol " + " indicates the fork length of fish at tagging that were detected at an interrogation site after tagging. Vertical arrows indicate the break between age-0, age-1, and age-2 or older bull trout. 


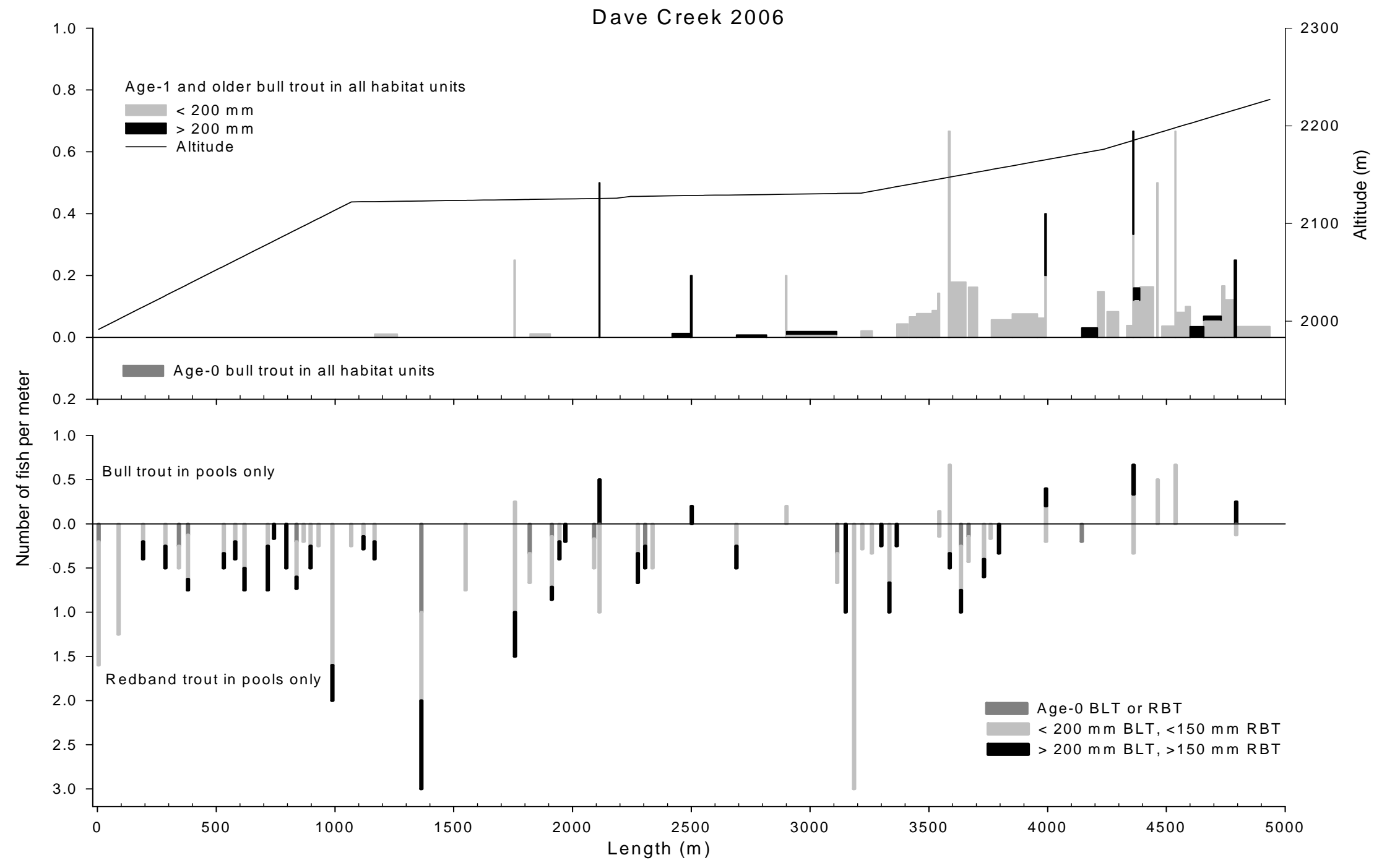

Figure 25. Number of bull trout (BLT) per meter by size class for all habitat units sampled along with altitude (upper graph) and the number of bull trout and redband trout (RBT) per meter by size class in pools only (lower graph) in Dave Creek (rkm 6.8 - 11.7), Nevada, 2006. 


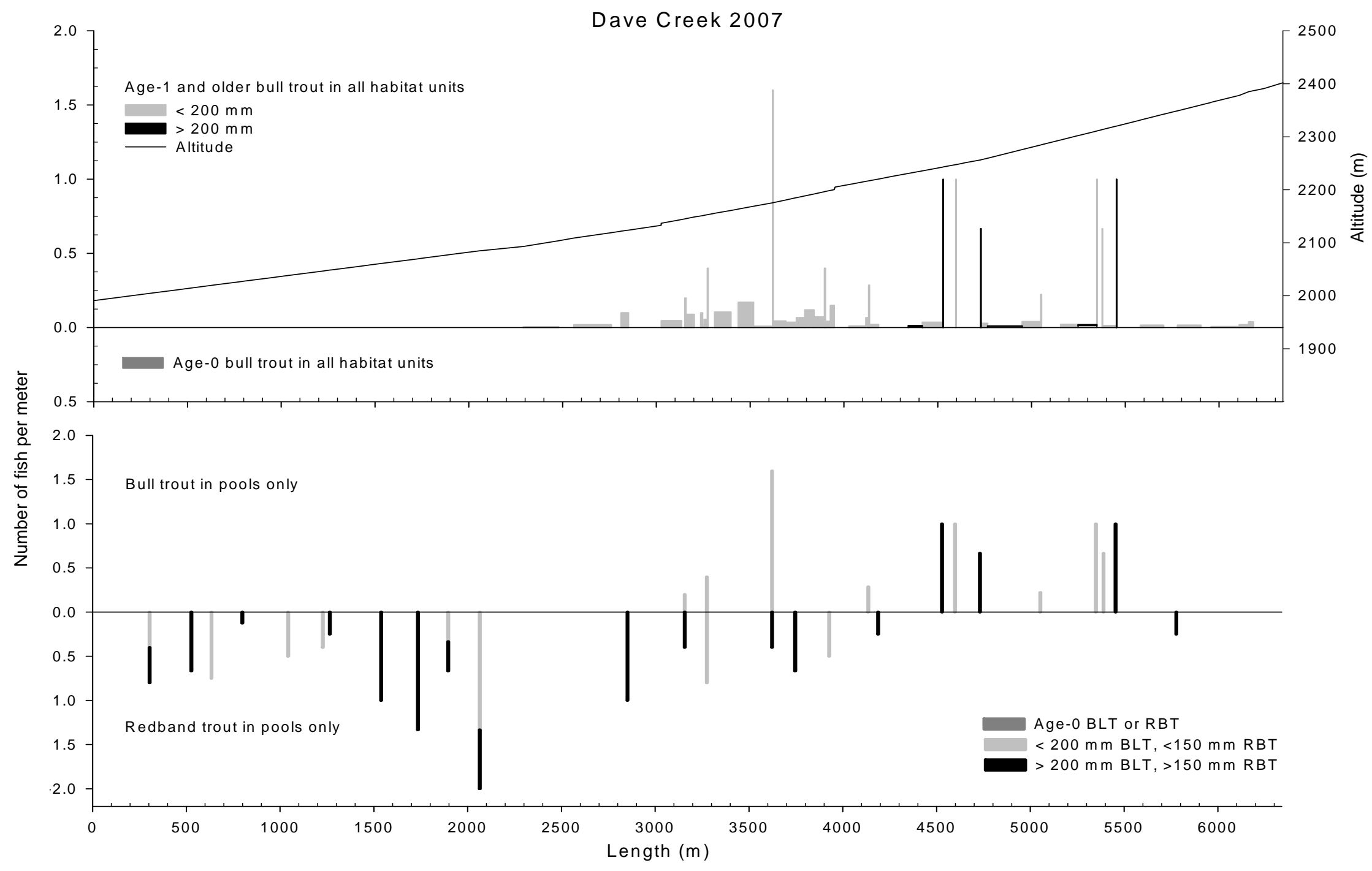

Figure 26. Number of bull trout (BLT) per meter by size class for all habitat units sampled along with altitude (upper graph) and the number of bull trout and redband trout (RBT) per meter by size class in pools only (lower graph) in Dave Creek (rkm 6.8 - 14.0), Nevada, 2007. 

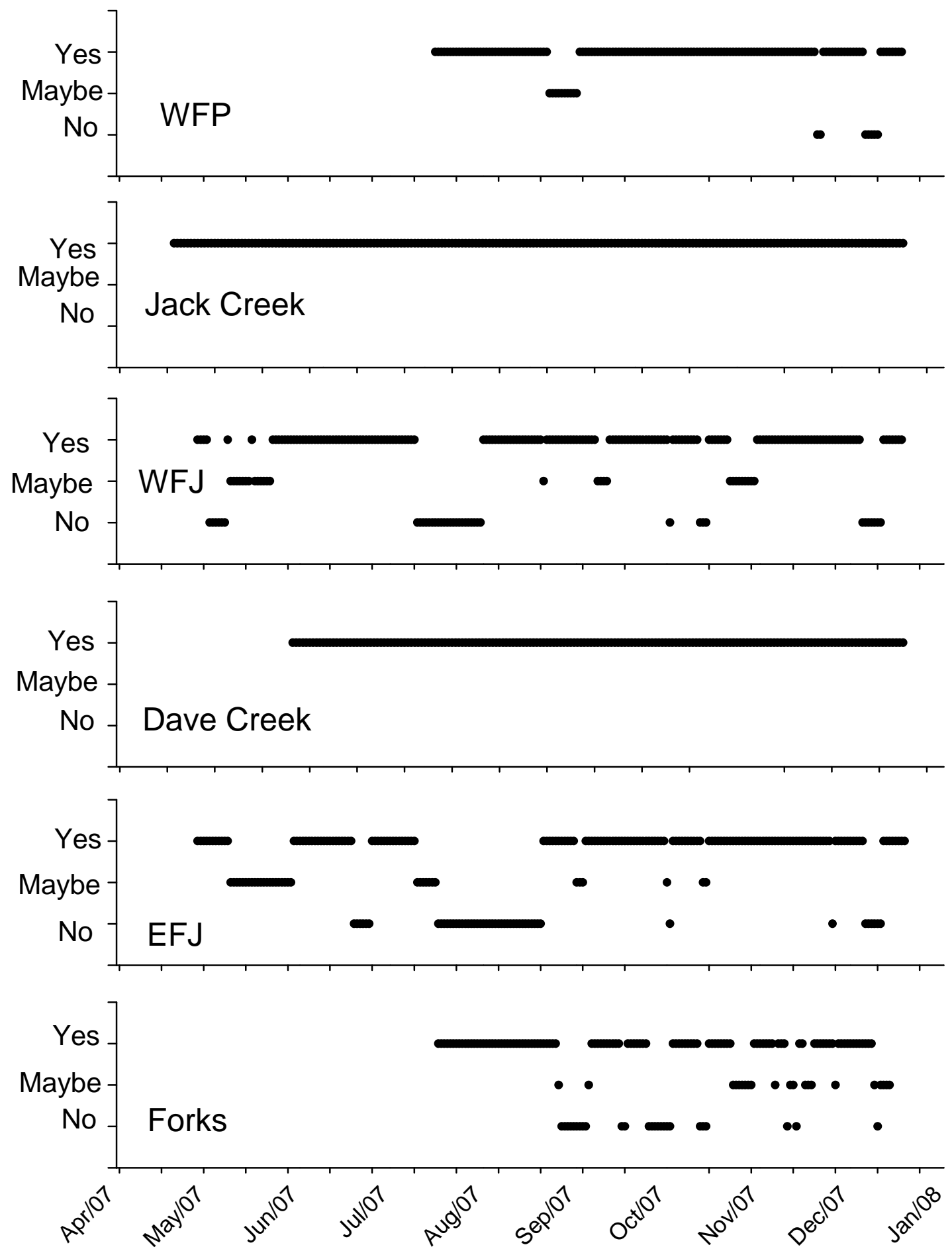

Date

Figure 27. Operational status of interrogation systems during 2007 in the Jarbidge River subbasin, Idaho and Nevada. Maybe indicates that although the system was operational, the distance at which a tag could be detected may have been reduced due to low battery voltage. 


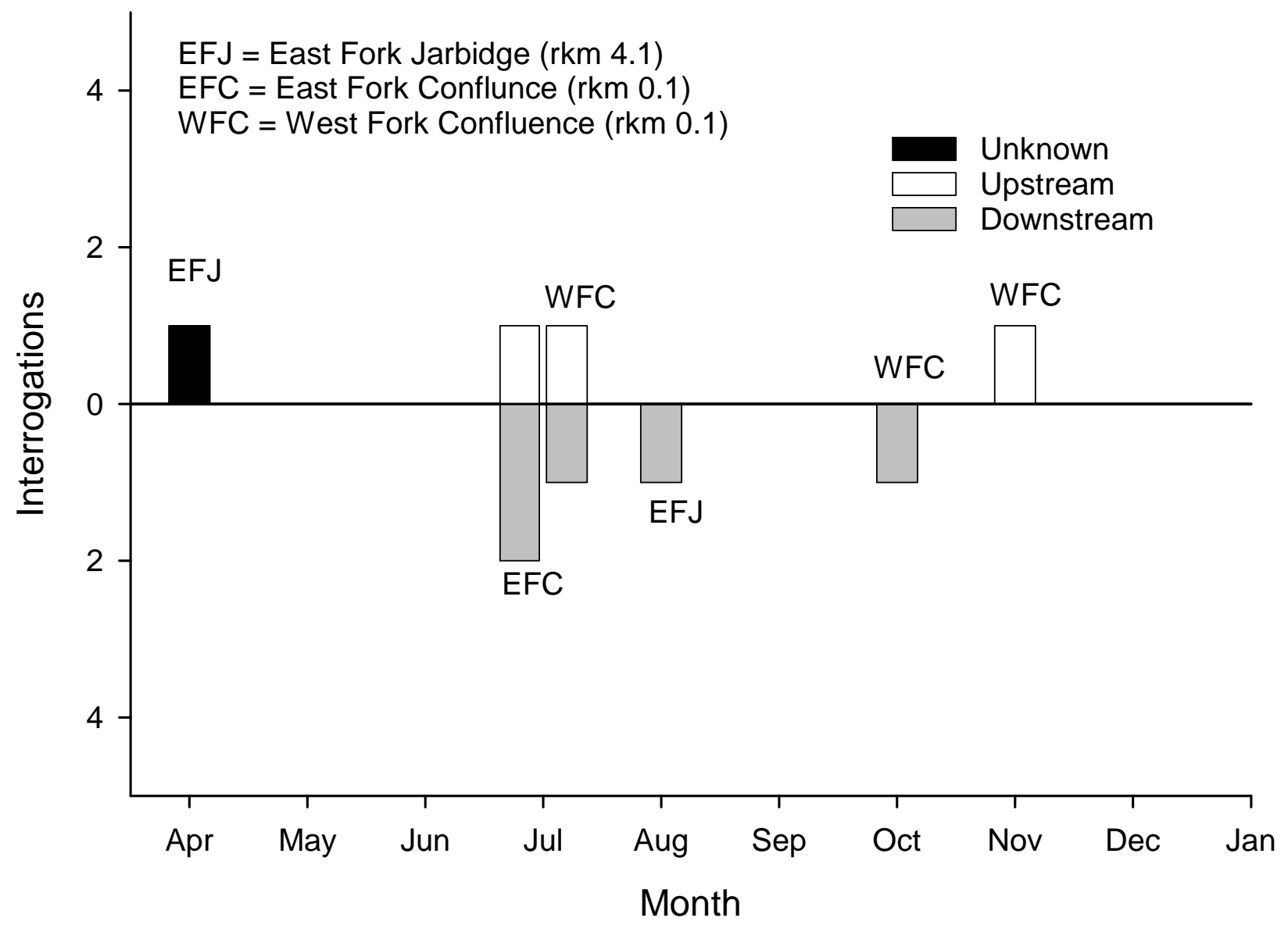

Figure 28. Number and movement direction of PIT tagged bull trout by month detected at the interrogation site in the East Fork Jarbidge River (EFJ, rkm 4.1), Idaho, and at the East Fork Jarbidge River and West Fork Jarbidge River (Forks, rkm 0.1) interrogation sites, Idaho, during 2007. 


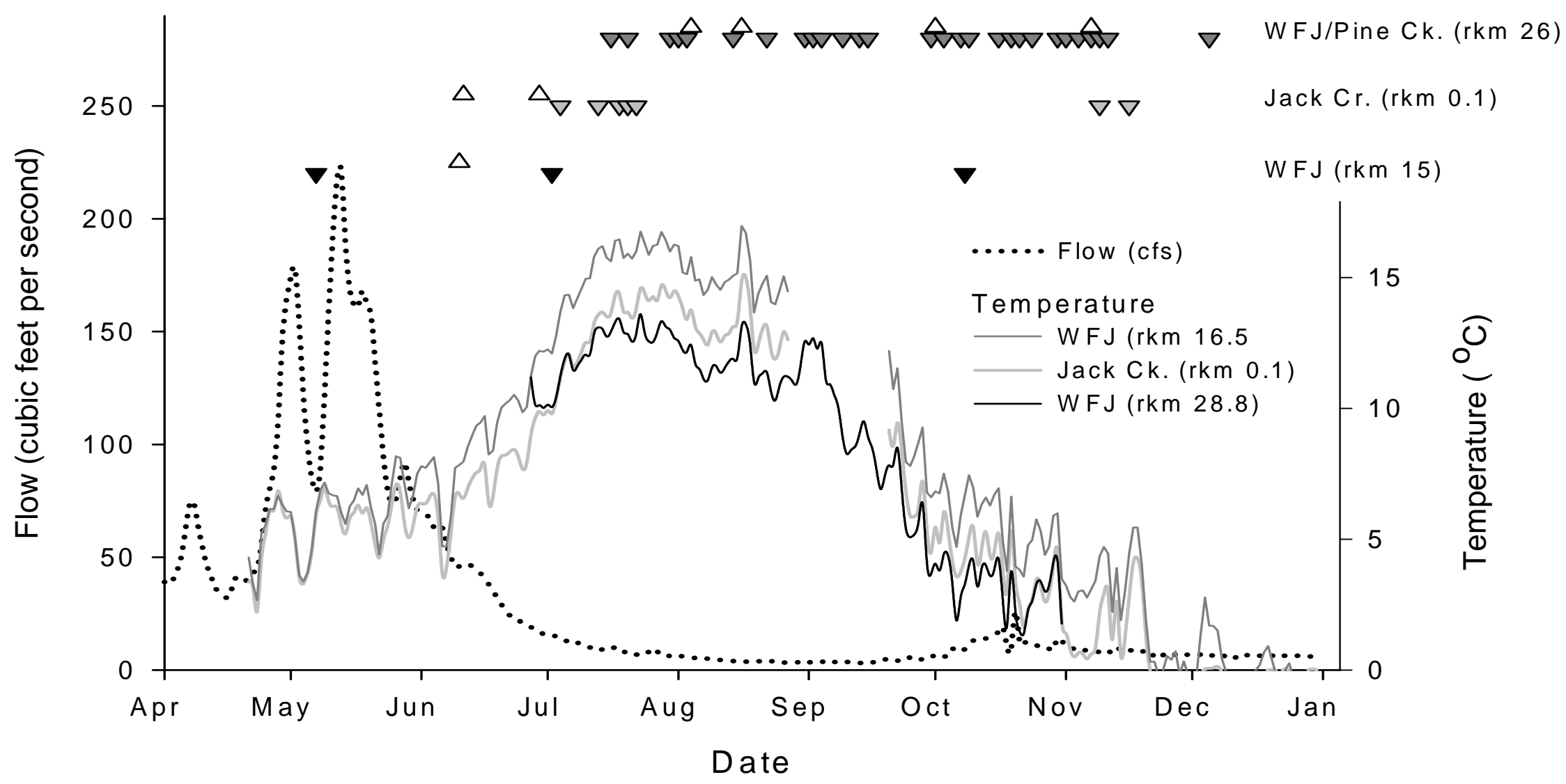

Figure 29. Streamflow (cfs), temperature, and direction of PIT tagged bull trout movements detected at interrogation sites in West Fork Jarbidge River ( $\mathrm{rkm}$ 15), Jack Creek ( $\mathrm{rkm} \mathrm{0.1),} \mathrm{and} \mathrm{West} \mathrm{Fork} \mathrm{Jarbidge} \mathrm{and} \mathrm{Pine} \mathrm{Creek} \mathrm{confluence} \mathrm{(} \mathrm{rkm} 26)$, Nevada, 2007. Triangles pointing up indicate upstream movement, and triangles pointing down indicate downstream movement. Stream flow measurements were taken from the USGS flow gage on the West Fork Jarbidge River (MFJ, rkm 19.2). Temperatures were taken at rkm 0.1 in Jack Cr., rkm 16.5 of the West Fork Jarbidge River below Jack Or., and rkm 28.8 in the West Fork Jarbidge River at Snowslide Gulch by BLM. 


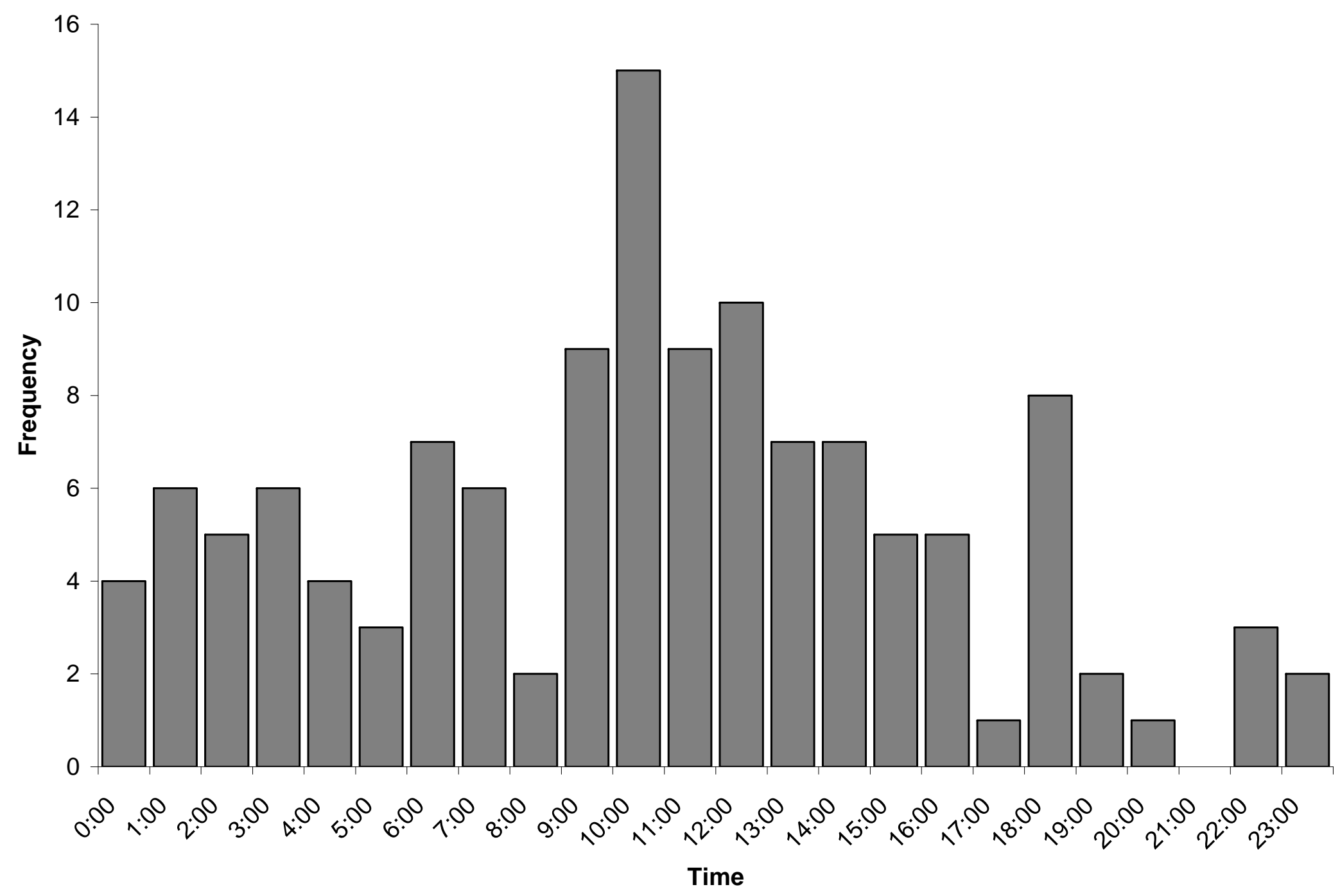

Figure 30. Time of day that PIT tagged bull trout passed any interrogation system in the Jarbidge River subbasin, Idaho and Nevada, in 2006 and 2007. 
Table 1. Number of bull trout the captured by electrofishing and PIT tagged in the East and West Forks of the Jarbidge River watershed in 2006.

[See figure 3 for additional information on sampling locations. Start and end river kilometer (rkm) were estimated with GPS positions and mapping software. All fish tagged in 2006 were tagged with 12-mm 134.4Khz PIT tags. Bolded numbers represent combined totals by stream for each sampling effort]

\begin{tabular}{|c|c|c|c|c|c|c|}
\hline $\begin{array}{l}\text { Watershed } \\
\quad \text { Stream or section }\end{array}$ & $\begin{array}{l}\text { Sampling } \\
\text { dates }\end{array}$ & $\begin{array}{l}\text { Rkm } \\
\text { (start) }\end{array}$ & $\begin{array}{l}\text { Rkm } \\
\text { (end) }\end{array}$ & $\begin{array}{c}\text { Bull } \\
\text { trout } \\
\text { captured }\end{array}$ & $\begin{array}{l}\text { PIT tags } \\
\text { deployed }\end{array}$ & $\begin{array}{c}\text { Genetic } \\
\text { samples } \\
\text { collected }\end{array}$ \\
\hline \multicolumn{7}{|l|}{ West Fork Jarbidge River (WFJ) } \\
\hline Gorge Gulch to just below Sawmill Cr. (WFJ) & $7 / 19-7 / 22$ & 27.0 & 30.2 & 76 & 73 & 41 \\
\hline Pine Cr. Campground to Gorge Gulch (WFJ) & $8 / 07,10 / 04$ & 23.5 & 27.0 & 7 & 7 & 5 \\
\hline Bourne Gulch to Pine Cr. campground (WFJ) & $9 / 24-9 / 26$ & 22.0 & 23.5 & 13 & 13 & 13 \\
\hline Instream interrogation site (WFJ) & $9 / 23-9 / 24$ & 14.5 & 15.5 & 1 & 1 & 1 \\
\hline Mainstem WFJ subtotal & & & & 97 & 94 & 60 \\
\hline Pine Creek & $7 / 23-9 / 26$ & 0 & 6.5 & 27 & 25 & 25 \\
\hline Jack Creek & 9/08-9/11 & 0 & 4.3 & 70 & 66 & 59 \\
\hline WFJ total & & \multicolumn{2}{|c|}{20.0} & 194 & 185 & 144 \\
\hline \multicolumn{7}{|l|}{ East Fork Jarbidge River (EFJ) } \\
\hline Dave Creek & 8/03-8/06 & 6.8 & 11.7 & 129 & 111 & 67 \\
\hline Mainstem wilderness (EFJ) & 8/17-8/19 & 15.6 & 24.7 & 13 & 13 & 13 \\
\hline Above Murphy Hot Springs (EFJ) & $10 / 03$ & 4.1 & 4.9 & 0 & 0 & 0 \\
\hline Fall Creek & $8 / 20$ & 0 & 2.0 & 9 & 9 & 9 \\
\hline Slide Creek & & & & 4 & 4 & 4 \\
\hline Confluence with EFJ & $8 / 21$ & 0 & 2.9 & 0 & 0 & 0 \\
\hline Middle & $8 / 22$ & 3.1 & 4.6 & 2 & 2 & 2 \\
\hline Upper & $8 / 22$ & 5.4 & 5.5 & 2 & 2 & 2 \\
\hline EFJ total & & \multicolumn{2}{|c|}{19.9} & 155 & 137 & 93 \\
\hline WFJ and EFJ combined total & & \multicolumn{2}{|c|}{39.9} & 349 & 322 & 237 \\
\hline
\end{tabular}


Table 2. Number of bull trout captured by electrofishing and PIT tagged in the West Fork Jarbidge River subbasin in 2007.

[See figure 2 for additional information on sampling locations. Start and end river kilometer (rkm) were estimated with GPS positions and mapping software. All fish tagged in 2007 were tagged with 12-mm 134.4Khz PIT tags. Bolded numbers represent combined totals of each sampling effort]

\begin{tabular}{|c|c|c|c|c|c|c|c|}
\hline $\begin{array}{l}\text { Watershed } \\
\quad \text { Stream or section }\end{array}$ & $\begin{array}{l}\text { Sampling } \\
\text { dates }\end{array}$ & $\begin{array}{l}\text { Rkm } \\
\text { (start) }\end{array}$ & $\begin{array}{l}\text { Rkm } \\
\text { (end) }\end{array}$ & $\begin{array}{c}\text { Bull } \\
\text { trout } \\
\text { captured }\end{array}$ & $\begin{array}{l}\text { PIT tags } \\
\text { deployed }\end{array}$ & $\begin{array}{l}\text { Recaptured } \\
\text { bull trout } \\
\text { from } 2006\end{array}$ & $\begin{array}{c}\text { Genetic } \\
\text { samples } \\
\text { collected }\end{array}$ \\
\hline \multicolumn{8}{|c|}{ West Fork Jarbidge River (WFJ) } \\
\hline WFJ & $\begin{array}{l}6 / 13-6 / 14 \\
6 / 20-6 / 22 \\
6 / 26,8 / 02 \\
8 / 14-8 / 15\end{array}$ & 21.7 & 32.2 & $272^{c}$ & 258 & 6 & 24 \\
\hline Pine Creek & $\begin{array}{c}8 / 16,8 / 21- \\
8 / 23,8 / 27, \\
8 / 29\end{array}$ & 0 & 5.9 & 430 & 380 & 5 & 97 \\
\hline \multicolumn{8}{|l|}{ Jack Creek } \\
\hline Marking sampling effort & $\begin{array}{c}\text { 8/06-8/07, } \\
8 / 09\end{array}$ & 0 & 5.4 & 93 & 70 & 9 & 78 \\
\hline $\begin{array}{l}\text { Recapture sampling effort } \\
\text { Jack Creek subtotal }\end{array}$ & $8 / 08,8 / 10$ & 0 & 5.4 & $\begin{array}{r}53^{\mathrm{a}} \\
146\end{array}$ & $\begin{array}{r}31 \\
101\end{array}$ & $1^{1^{\mathrm{b}}}$ & $\begin{array}{r}28 \\
106\end{array}$ \\
\hline Deer Creek & $9 / 10$ & 6.9 & 9.4 & 0 & 0 & 0 & 0 \\
\hline Buck Creek & $9 / 14$ & & & & & & \\
\hline Below private property & & 3.6 & 3.8 & 0 & 0 & 0 & 0 \\
\hline Above private property & & 12.7 & 13.1 & 0 & 0 & 0 & 0 \\
\hline Buck Creek subtotal & & & & $\mathbf{0}$ & $\mathbf{0}$ & $\mathbf{0}$ & $\mathbf{0}$ \\
\hline WFJ total & & \multicolumn{2}{|c|}{$24.9^{c}$} & 848 & 739 & 21 & 227 \\
\hline
\end{tabular}

a Twenty-three bull trout were recaptured from the marking sampling effort the previous day and were not included.

${ }^{\mathrm{b}}$ The number of recaptured bull trout does not include fish that were tagged and recaptured within 2007.

${ }^{\mathrm{c}}$ Distance does not include areas that were re-sampled. 
Table 3. Number of bull trout captured by electrofishing and PIT tagged in the East Fork Jarbidge River subbasin in 2007.

[See figure 3 for additional information on sampling locations. Start and end rkm were estimated with GPS positions and mapping software. All fish tagged in 2007 were tagged with 12-mm 134.4Khz PIT tags. The number of recaptured bull trout does not include fish that were tagged and recaptured within 2007. Bolded numbers represent combined totals by stream for each sampling effort]

\begin{tabular}{|c|c|c|c|c|c|c|c|}
\hline $\begin{array}{l}\text { Watershed } \\
\quad \text { Stream or section }\end{array}$ & $\begin{array}{l}\text { Sampling } \\
\text { dates }\end{array}$ & $\begin{array}{l}\text { Rkm } \\
\text { (start) }\end{array}$ & $\begin{array}{l}\text { Rkm } \\
\text { (end) }\end{array}$ & $\begin{array}{c}\text { Bull } \\
\text { trout } \\
\text { captured }\end{array}$ & $\begin{array}{l}\text { PIT tags } \\
\text { deployed }\end{array}$ & $\begin{array}{l}\text { Recaptured } \\
\text { bull trout } \\
\text { from } 2006\end{array}$ & $\begin{array}{c}\text { Genetic } \\
\text { samples } \\
\text { collected }\end{array}$ \\
\hline \multicolumn{8}{|l|}{ East Fork Jarbidge River (EFJ) } \\
\hline \multicolumn{8}{|l|}{ EFJ } \\
\hline Below Slide Cr. to Slide Cr. & $7 / 17$ & 23.0 & 23.5 & 1 & 0 & 1 & 1 \\
\hline Wilderness (rkm 32.5) & $7 / 12-7 / 14$ & 32.5 & 35.0 & 323 & 312 & $0^{\mathrm{a}}$ & 203 \\
\hline Unnamed East Fork tributary & $7 / 13$ & 0 & 0.3 & 13 & 12 & 0 & 8 \\
\hline EFJ subtotal & & & & 337 & 324 & 1 & 212 \\
\hline \multicolumn{8}{|l|}{ Cougar Creek } \\
\hline Confluence with EFJ & $7 / 11$ & 0 & 0.7 & 0 & 0 & 0 & 0 \\
\hline Site 2 & $7 / 11$ & 1.2 & 1.5 & 1 & 1 & 0 & 1 \\
\hline Site 3 to barrier & $7 / 11-7 / 12$ & 1.8 & 3.1 & 6 & 6 & 0 & 6 \\
\hline Cougar Creek subtotal & & & & 7 & 7 & $\mathbf{0}$ & 7 \\
\hline Fall Creek & $7 / 15$ & 1.4 & 3.2 & 30 & 30 & 0 & 30 \\
\hline \multicolumn{8}{|l|}{ Slide Creek } \\
\hline Site 1 & $7 / 16$ & 4.6 & 5.7 & 1 & 1 & 0 & 1 \\
\hline Site 2 to barrier & 7/16-7/17 & 5.8 & 7.7 & 2 & 2 & 0 & 2 \\
\hline Slide Creek subtotal & & & & 3 & 3 & $\mathbf{0}$ & 3 \\
\hline Gods Pocket Creek & $7 / 17$ & 0.6 & 0.9 & 0 & 0 & 0 & 0 \\
\hline \multicolumn{8}{|l|}{ Dave Creek } \\
\hline Initial sampling effort & 6/28-7/02 & 6.8 & 14.0 & 105 & 100 & 3 & 81 \\
\hline \multirow{2}{*}{ Recapture sampling effort } & 9/11 & 10.5 & 13.9 & 23 & 11 & $0^{\mathrm{b}}$ & 8 \\
\hline & & & & 128 & 111 & 3 & 89 \\
\hline \multicolumn{8}{|l|}{ Dave Creek subtotal } \\
\hline EFJ total & & \multicolumn{2}{|c|}{$17.8^{c}$} & 505 & 475 & 4 & 342 \\
\hline EFJ and WFJ combined total & & \multicolumn{2}{|c|}{$42.7^{c}$} & 1,353 & 1,214 & 25 & 569 \\
\hline
\end{tabular}

a Nine bull trout were recaptured from previous day of 2007 sampling in Wilderness and were not included.

${ }^{\mathrm{b}}$ Seven bull trout were recaptured from initial 2007 sampling of Dave Creek and were not included.

${ }^{\mathrm{c}}$ Distance does not include areas that were re-sampled. 
Table 4. Location, altitude and estimated length of fish and habitat surveys conducted in the Jarbidge River watershed during 2006.

[See figures 2 and 3 for additional information on sampling locations. Altitudes were obtained using Google ${ }^{\circledR}$ Earth as altitudes given by GPS unit were not accurate. Estimated length was calculated by summing the visually estimated lengths of each habitat unit]

\begin{tabular}{|c|c|c|c|c|c|c|c|}
\hline \multirow{2}{*}{$\begin{array}{l}\text { Watershed } \\
\text { Stream or section }\end{array}$} & \multicolumn{2}{|c|}{$\begin{array}{l}\text { GPS reading } \\
\text { Start of reach }\end{array}$} & \multicolumn{2}{|c|}{$\begin{array}{l}\text { GPS reading } \\
\text { End of reach }\end{array}$} & \multicolumn{2}{|c|}{ Altitude (m) } & \multirow{2}{*}{$\begin{array}{l}\text { Estimated } \\
\text { length }(\mathrm{m})^{\mathrm{d}}\end{array}$} \\
\hline & North & West & North & West & SOR & EOR & \\
\hline \multicolumn{8}{|l|}{ West Fork Jarbidge River } \\
\hline All sites combined & $41^{\circ} 55^{\prime} 49.8^{\prime \prime}$ & $115^{\circ} 25^{\prime} 04.3^{\prime \prime}$ & $41^{\circ} 48^{\prime} 07.8^{\prime \prime}$ & $115^{\circ} 24^{\prime} 12.1^{\prime \prime}$ & 1,753 & 2,225 & 12,854 \\
\hline Gorge Gulch - below Sawmill Creek & $41^{\circ} 49^{\prime} 56.5^{\prime \prime}$ & $115^{\circ} 25^{\prime} 17.9^{\prime}$ & $41^{\circ} 48^{\prime} 07.8^{\prime \prime}$ & $115^{\circ} 24^{\prime} 12.1^{\prime \prime}$ & 2,062 & 2,225 & 4,389 \\
\hline Pine Creek camp - Gorge Gulch & $41^{\circ} 50^{\prime} 03.1 ”$ & $115^{\circ} 25^{\prime} 30.6^{\prime}$ & $41^{\circ} 50^{\prime} 03.7^{\prime \prime}$ & $115^{\circ} 25^{\prime} 38.6^{\prime \prime}$ & 2,039 & 2,062 & 1,431 \\
\hline Bourne Gulch - Pine Creek camp & $41^{\circ} 52^{\prime} 09.2^{\prime \prime}$ & $115^{\circ} 25^{\prime} 58.6^{\prime}$ & $41^{\circ} 50^{\prime} 03.1^{\prime \prime}$ & $115^{\circ} 25^{\prime} 30.6^{\prime \prime}$ & 1,890 & 2,039 & 4,822 \\
\hline Antenna site & $41^{\circ} 55^{\prime} 49.8^{\prime \prime}$ & $115^{\circ} 25^{\prime} 04.3^{\prime \prime}$ & $41^{\circ} 54^{\prime} 54.1^{\prime \prime}$ & $115^{\circ} 25^{\prime} 27.8^{\prime \prime}$ & 1,753 & 1,826 & 2,213 \\
\hline Pine Creek & $41^{\circ} 50^{\prime} 03.1 ”$ & $115^{\circ} 25^{\prime} 30.6^{\prime}$ & $41^{\circ} 47^{\prime} 05.4^{\prime \prime}$ & $115^{\circ} 27^{\prime} 27.4^{\prime \prime}$ & 2,039 & 2,388 & 5,529 \\
\hline Jack Creek & $41^{\circ} 54^{\prime} 39.2^{\prime \prime}$ & $115^{\circ} 25^{\prime} 22.6^{\prime \prime}$ & $41^{\circ} 53^{\prime} 23.7^{\prime \prime}$ & $115^{\circ} 23^{\prime} 07.7^{\prime \prime}$ & 1,673 & 2,138 & 5,224 \\
\hline East Fork Jarbidge River & \multirow{2}{*}{\multicolumn{2}{|c|}{$\mathrm{RNT}^{\mathrm{a}}$}} & & & & & \\
\hline All sites combined & & & $41^{\circ} 47^{\prime} 30.0^{\prime \prime}$ & 115¹9’21.8” & RNT & 2,235 & 8,821 \\
\hline Above Murphy & \multicolumn{2}{|c|}{ RNT } & \multicolumn{2}{|c|}{ RNT } & RNT & RNT & 820 \\
\hline Wilderness & $41^{\circ} 51^{\prime} 59.6 ”$ & $115^{\circ} 18^{\prime} 45.8^{\prime}$ & $41^{\circ} 47^{\prime} 30.0^{\prime \prime}$ & 115¹9’21.8” & 1,962 & 2,235 & 8,003 \\
\hline Slide Creek & $41^{\circ} 52^{\prime} 00.0^{\prime \prime}$ & $115^{\circ} 18^{\prime} 45.9^{\prime \prime}$ & $41^{\circ} 50^{\prime} 16.1^{\prime \prime}$ & $115^{\circ} 15^{\prime} 59.8^{\prime \prime}$ & 1,958 & 2,252 & 4,601 \\
\hline Fall Creek & $41^{\circ} 51^{\prime} 22.6 ”$ & $115^{\circ} 18^{\prime} 52.8^{\prime}$ & $\mathrm{RN}$ & & 1,944 & 2,073 & 2,310 \\
\hline \multirow[t]{2}{*}{ Dave Creek } & $41^{\circ} 56^{\prime} 27.0^{\prime \prime}$ & $115^{\circ} 22^{\prime} 08.9^{\prime \prime}$ & $41^{\circ} 54^{\prime} 00.3^{\prime \prime}$ & $115^{\circ} 20^{\prime} 58.7^{\prime \prime}$ & 1,986 & 2,261 & 4,900 \\
\hline & & & & & \multicolumn{2}{|c|}{ Total length surveyed } & 44,437 \\
\hline
\end{tabular}

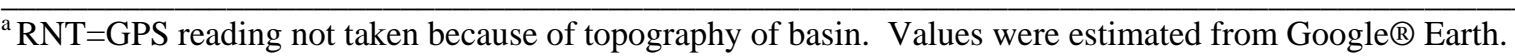


Table 5. Location, altitude and estimated length of fish and habitat surveys conducted in the Jarbidge River watershed during 2007.

[See figures 2 and 3 for additional information on sampling locations. Altitudes were obtained using Google ${ }^{\circledR}$ Earth as altitudes given by GPS unit were not accurate. Estimated length was calculated by summing the visually estimated lengths of each habitat unit]

\begin{tabular}{|c|c|c|c|c|c|c|c|}
\hline \multirow{2}{*}{$\begin{array}{l}\text { Watershed } \\
\quad \text { Stream or section }\end{array}$} & \multicolumn{2}{|c|}{$\begin{array}{l}\text { GPS reading } \\
\text { Start of reach }\end{array}$} & \multicolumn{2}{|c|}{$\begin{array}{l}\text { GPS reading } \\
\text { End of reach }\end{array}$} & \multicolumn{2}{|c|}{ Altitude (m) } & \multirow{2}{*}{$\begin{array}{l}\text { Estimated } \\
\text { length }(\mathrm{m})\end{array}$} \\
\hline & North & West & North & West & SOR & EOR & \\
\hline \multicolumn{8}{|l|}{ West Fork Jarbidge River (WFJ) } \\
\hline WFJ & 4152’09.9” & $115^{\circ} 25^{\prime} 55.2^{\prime}$ & $41^{\circ} 47^{\prime} 34.4^{\prime \prime}$ & $115^{\circ} 23^{\prime} 47.3^{\prime \prime}$ & 1,900 & 2,317 & 8,871 \\
\hline Pine Creek & $41^{\circ} 50^{\prime} 03.4^{\prime \prime}$ & $115^{\circ} 25^{\prime} 31.1^{\prime \prime}$ & $41^{\circ} 47^{\prime} 24.8^{\prime \prime}$ & $115^{\circ} 27^{\prime} 00.5^{\prime}$ & 2,009 & 2,326 & 4,490 \\
\hline Jack Creek & $41^{\circ} 54^{\prime} 43.1^{\prime \prime}$ & $115^{\circ} 25^{\prime} 29.0 ”$ & $41^{\circ} 52^{\prime} 53.1^{\prime \prime}$ & $115^{\circ} 22^{\prime} 47.5^{\prime \prime}$ & 1,795 & 2,270 & 5,347 \\
\hline Deer Creek & $41^{\circ} 52^{\prime} 43.8^{\prime \prime}$ & $115^{\circ} 27^{\prime} 07.5^{\prime \prime}$ & $41^{\circ} 51^{\prime} 42.0^{\prime \prime}$ & $115^{\circ} 28^{\prime} 01.6^{\prime \prime}$ & 2,143 & 2,267 & 1,754 \\
\hline \multicolumn{8}{|l|}{ Buck Creek } \\
\hline Below private property & 4158’28.2” & $115^{\circ} 25^{\prime} 44.1^{\prime \prime}$ & $41^{\circ} 58 ’ 52.2^{\prime \prime}$ & $115^{\circ} 25^{\prime} 57.6^{\prime \prime}$ & 1,834 & 1,836 & 163 \\
\hline Above private property & $41^{\circ} 54^{\prime} 40.5^{\prime \prime}$ & $115^{\circ} 28^{\prime} 52.1^{\prime \prime}$ & $41^{\circ} 54^{\prime} 32.0^{\prime \prime}$ & $115^{\circ} 29^{\prime} 01.3^{\prime}$ & 2,046 & 2,058 & 352 \\
\hline \multicolumn{8}{|l|}{ East Fork Jarbidge River (EFJ) } \\
\hline EFJ below Slide Creek to Slide Creek confluence & $41^{\circ} 52^{\prime} 10.7^{\prime \prime}$ & $115^{\circ} 18^{\prime} 48.4^{\prime}$ & $41^{\circ} 51^{\prime} 59.2^{\prime \prime}$ & $115^{\circ} 18^{\prime} 45.5^{\prime \prime}$ & 1,930 & 1,938 & 588 \\
\hline Upper EFJ & $41^{\circ} 47^{\prime} 26.5^{\prime}$ & $115^{\circ} 19^{\prime} 21.6^{\prime \prime}$ & $41^{\circ} 46^{\prime} 59.9 ”$ & $115^{\circ} 20^{\prime} 45.1^{\prime}$ & 2,244 & 2,419 & 2,709 \\
\hline \multicolumn{8}{|l|}{ Cougar Creek } \\
\hline Confluence with EFJ & $41^{\circ} 50^{\prime} 24.3^{\prime \prime}$ & $115^{\circ} 19^{\prime} 12.8^{\prime}$ & 4150’19.8” & $115^{\circ} 19^{\prime} 38.9^{\prime}$ & 2,004 & 2,044 & 665 \\
\hline Site 2 & $41^{\circ} 50^{\prime} 04.4^{\prime \prime}$ & $115^{\circ} 19^{\prime} 47.9 ”$ & $41^{\circ} 49^{\prime} 52.5^{\prime \prime}$ & $115^{\circ} 19^{\prime} 52.7^{\prime}$ & 2,076 & 2,100 & 511 \\
\hline Site 3 to barrier & $41^{\circ} 49^{\prime} 44.9^{\prime \prime}$ & $115^{\circ} 19^{\prime} 55.8^{\prime \prime}$ & $41^{\circ} 49^{\prime} 04.3^{\prime \prime}$ & $115^{\circ} 20^{\prime} 10.1^{\prime \prime}$ & 2,126 & 2,284 & 1,453 \\
\hline Dave Creek & 4156’26.9”' & 115²2’09.1” & 4152’56.0” & $115^{\circ} 21 ’ 18.9 ”$ & 1,991 & 2,402 & 6,340 \\
\hline Fall Creek & $41^{\circ} 50^{\prime} 55.5^{\prime \prime}$ & $115^{\circ} 19^{\prime} 38.2^{\prime}$ & $41^{\circ} 50^{\prime} 11.8^{\prime \prime}$ & $115^{\circ} 20 ’ 19.1^{\prime \prime}$ & 2,022 & 2,181 & 1,675 \\
\hline \multicolumn{8}{|l|}{ Slide Creek } \\
\hline Site 1 & $41^{\circ} 50^{\prime} 22.2^{\prime \prime}$ & $115^{\circ} 16^{\prime} 37.9 ”$ & $41^{\circ} 50^{\prime} 18.1^{\prime \prime}$ & $115^{\circ} 15^{\prime} 58.6 ”$ & 2,175 & 2,248 & 1,133 \\
\hline Site 2 to barrier & 4150’18.9” & $115^{\circ} 15^{\prime} 52.6^{\prime \prime}$ & $41^{\circ} 51^{\prime} 04.8^{\prime \prime}$ & $115^{\circ} 15^{\prime} 12.5^{\prime}$ & 2,249 & 2,442 & 1,933 \\
\hline Gods Pocket Creek & $41^{\circ} 50^{\prime} 37.1^{\prime \prime}$ & $115^{\circ} 17^{\prime} 46.1 ”$ & 4150’26.6” & $115^{\circ} 17^{\prime} 51.0 ”$ & 2,120 & 2,146 & 498 \\
\hline Unnamed East Fork Tributary & $41^{\circ} 46^{\prime} 56.7^{\prime \prime}$ & $115^{\circ} 19^{\prime} 46.4^{\prime \prime}$ & $41^{\circ} 46^{\prime} 46.4 ”$ & $115^{\circ} 19^{\prime} 47.9^{\prime \prime}$ & 2,318 & 2,360 & 248 \\
\hline
\end{tabular}


Table 6. Number ( $n$ ) of bull trout captured, the sampling distance (rkm), the number of bull trout captured with a fork length greater than $200 \mathrm{~mm}$, the number of bull trout with a fork length greater than $250 \mathrm{~mm}$, the minimum (min) fork length, the maximum (max) fork length, and weight of bull trout for each creek sampled in the Jarbidge River watershed, Nevada, in 2006-2007.

[The number of fish captured does not include fish that were tagged and recaptured within 2007. Figures 2 and 3 contain additional location information. River kilometer (rkm) was estimated, using mapping software, from a start point of the confluence of the East Fork and West Fork Jarbidge River, or for tributaries, the confluence with East Fork or West Fork Jarbidge River]

\begin{tabular}{|c|c|c|c|c|c|c|c|c|c|}
\hline \multirow{2}{*}{$\begin{array}{l}\text { Watershed } \\
\text { Stream }\end{array}$} & \multicolumn{2}{|c|}{$\begin{array}{l}\text { River kilometer } \\
\text { (rkm) }\end{array}$} & \multirow[b]{2}{*}{$n$} & \multicolumn{2}{|c|}{ No. with fork length } & \multicolumn{2}{|c|}{$\begin{array}{c}\text { Fork length } \\
(\mathrm{mm})\end{array}$} & \multicolumn{2}{|c|}{$\begin{array}{c}\text { Weight } \\
\text { (g) }\end{array}$} \\
\hline & (start) & (end) & & $>200 \mathrm{~mm}$ & $>250 \mathrm{~mm}$ & $\min$ & $\max$ & $\min$ & $\max$ \\
\hline \multicolumn{10}{|c|}{ West Fork Jarbidge River (WFJ)-2006 } \\
\hline $\mathrm{WFJ}^{\mathrm{a}}$ & 14.5 & 30.2 & 97 & 11 & 3 & 23 & 330 & 0.3 & 508.0 \\
\hline Pine Cr. & 0 & 6.6 & 27 & 6 & 0 & 39 & 243 & 0.7 & 161.0 \\
\hline \multirow{2}{*}{ Jack Cr. } & 0 & 4.3 & 70 & 8 & 3 & 61 & 310 & 2.5 & 268.0 \\
\hline & & otal & 194 & 25 & 6 & & & & \\
\hline \multicolumn{10}{|c|}{ West Fork Jarbidge River (WFJ)-2007 } \\
\hline WFJ & 24.8 & 32.2 & 272 & 19 & 3 & 28 & 273 & 3.6 & 222.8 \\
\hline Pine Cr. & 0 & 5.9 & 430 & 12 & 3 & 55 & 387 & 1.8 & 650.3 \\
\hline \multirow[t]{2}{*}{ Jack Cr. } & 0 & 5.4 & 146 & 14 & 2 & 42 & 283 & 1.0 & 230.8 \\
\hline & & otal & 848 & 45 & 8 & & & & \\
\hline \multicolumn{10}{|c|}{ East Fork Jarbidge River (EFJ)-2006 } \\
\hline EFJ & 16.0 & 22.6 & 13 & 5 & 1 & 135 & 260 & 22.4 & 194.5 \\
\hline Dave Cr. & 6.8 & 11.7 & 129 & 16 & 0 & 97 & 229 & 9.3 & 148.0 \\
\hline Fall Cr. & 0 & 2.0 & 9 & 0 & 1 & 119 & $360^{\mathrm{b}}$ & 16.1 & 440.6 \\
\hline \multirow[t]{2}{*}{ Slide Cr. ${ }^{\text {a }}$} & 0 & 2.1 & 4 & 0 & 1 & 189 & 300 & 62.8 & 230.2 \\
\hline & & otal & 155 & 21 & 3 & & & & \\
\hline \multicolumn{10}{|c|}{ East Fork Jarbidge River (EFJ)-2007 } \\
\hline $\mathrm{EFJ}^{\mathrm{a}}$ & 23.0 & 35.0 & 324 & 63 & 8 & 78 & $400^{\mathrm{b}}$ & 4.7 & 767.2 \\
\hline Dave Cr. & 6.8 & 14.0 & 128 & 7 & 0 & 59 & 232 & 1.8 & 145.4 \\
\hline Fall Cr. & 1.4 & 3.2 & 30 & 4 & 0 & 79 & 247 & 4.8 & 196.9 \\
\hline Slide Cr. ${ }^{\text {a }}$ & 4.6 & 7.7 & 3 & 1 & 0 & 95 & 220 & 8.7 & 122.7 \\
\hline Cougar Cr. & 0 & 3.1 & 7 & & & & & & \\
\hline a & & & & 4 & 2 & 138 & 340 & 26.5 & 420.4 \\
\hline \multirow[t]{2}{*}{ EFJ Trib. } & 0 & 0.3 & 13 & 6 & 0 & 130 & 238 & 20.7 & 176.9 \\
\hline & & otal & 505 & 85 & 10 & & & & \\
\hline
\end{tabular}

${ }^{a}$ River kilometer represents the overall range of where sampling occurred. The entire distance was not completely sampled, as certain sections of river were skipped; see figures 2 and 3 for details.

${ }^{\mathrm{b}}$ Largest fish captured in Fall Ck. in 2006 and the largest fish captured in the East Fork Jarbidge River in 2007 was the same fish. 
Table 7. Number ( $n$ ) of bull trout (BLT) collected, survey length, percent of stream length with bull trout, the percent of habitat units with at least one bull trout, the percent of stream length that was pool-like, and percent of bull trout found in pools in the Jarbidge River watershed in 2006-2007.

[River kilometer was estimated, using mapping software, from a start point of the confluence of the East Fork and West Fork Jarbidge River, or for tributaries, the confluence with either the East Fork or West Fork Jarbidge River. Habitat units were defined as either pool or non-pool]

\begin{tabular}{|c|c|c|c|c|c|c|c|c|}
\hline \multirow{2}{*}{$\begin{array}{l}\text { Watershed } \\
\text { Stream }\end{array}$} & \multirow[b]{2}{*}{$n$} & \multicolumn{2}{|c|}{ River kilometer } & \multirow{2}{*}{$\begin{array}{l}\text { Survey } \\
\text { length (m) }\end{array}$} & \multirow{2}{*}{$\begin{array}{l}\% \text { length } \\
\text { with BLT }\end{array}$} & \multirow{2}{*}{$\begin{array}{c}\text { \% habitat } \\
\text { units with } \\
\text { BLT }\end{array}$} & \multirow{2}{*}{$\begin{array}{c}\text { \% length } \\
\text { identified } \\
\text { as pools }\end{array}$} & \multirow{2}{*}{$\begin{array}{c}\% \text { BLT in } \\
\text { pools }\end{array}$} \\
\hline & & (start) & (end) & & & & & \\
\hline \multicolumn{9}{|c|}{ West Fork Jarbidge River (WFJ)-2006 } \\
\hline $\mathrm{WFJ}^{\mathrm{a}}$ & 97 & 14.5 & 30.2 & 12,856 & 20 & 21 & 16 & 20 \\
\hline Pine Cr. & 27 & 0 & 6.6 & 5,530 & 21 & 14 & 10 & 30 \\
\hline Jack Cr. & 70 & 0 & 4.3 & 5,224 & 24 & 29 & 10 & 44 \\
\hline \multicolumn{9}{|c|}{ West Fork Jarbidge River (WFJ)-2007 } \\
\hline WFJ & 272 & 24.8 & 32.2 & 8,872 & 37 & 50 & 12 & 15 \\
\hline Pine Cr. & 430 & 0 & 5.9 & 4,490 & 57 & 83 & 9 & 10 \\
\hline Jack Cr. & 146 & 0 & 5.4 & 5,347 & 27 & 45 & 8 & 39 \\
\hline \multicolumn{9}{|c|}{ East Fork Jarbidge River (EFJ)-2006 } \\
\hline EFJ & 13 & 16.0 & 22.6 & 8,003 & 8 & 5 & 19 & 25 \\
\hline Dave Cr. & 129 & 6.8 & 11.7 & 4,903 & 38 & 46 & 7 & 15 \\
\hline Fall Cr. & 9 & 0 & 2.0 & 2,311 & 15 & 8 & 14 & 22 \\
\hline Slide Cr. ${ }^{\text {a }}$ & 4 & 0 & 2.1 & 4,625 & 3 & 3 & 12 & 0 \\
\hline \multicolumn{9}{|c|}{ East Fork Jarbidge River (EFJ)-2007 } \\
\hline $\mathrm{EFJ}^{\mathrm{a}}$ & 324 & 23.0 & 35.0 & 3,297 & 52 & 83 & 13 & 19 \\
\hline Dave Cr. & 128 & 6.8 & 14.0 & 6,340 & 41 & 62 & 2 & 10 \\
\hline Fall Cr. & 30 & 1.4 & 3.2 & 1,675 & 26 & 28 & 9 & 20 \\
\hline Slide Cr. ${ }^{\text {a }}$ & 3 & 4.6 & 7.7 & 3,066 & 3 & 3 & 4 & 0 \\
\hline Cougar Cr. ${ }^{a}$ & 7 & 0 & 3.1 & 2,612 & 6 & 4 & 16 & 71 \\
\hline Unnamed Trib. & 13 & 0 & 0.3 & 248 & 63 & 72 & 5 & 0 \\
\hline
\end{tabular}

${ }^{a}$ River kilometer represents the overall range of where sampling occurred. The entire distance was not completely sampled, as certain sections of river were skipped; see figures 2 and 3 for more detail. 
Table 8. Location and installation date of passive integrated transponder (PIT) tag interrogation units installed in the Jarbidge River watershed in 2006-2007, and the number of bull trout (BLT) interrogated by tagging location in 2006-2007.

[River kilometer was estimated, using mapping software, from a start point of the confluence of the East Fork and West Fork Jarbidge River, or for tributaries, the confluence with either the East Fork or West Fork Jarbidge River. The 4 out of 8 tagging streams listed were the only ones that had fish detected at the interrogators. Fish detected on more than one array are counted more than once]

\begin{tabular}{|c|c|c|c|c|c|c|}
\hline \multirow{3}{*}{$\begin{array}{l}\text { Watershed } \\
\text { Interrogation site }\end{array}$} & \multirow{3}{*}{ Start date } & \multirow{3}{*}{$\begin{array}{c}\text { River } \\
\text { kilometer }\end{array}$} & \multicolumn{4}{|c|}{ No. of BLT detected by tagging stream } \\
\hline & & & \multicolumn{3}{|c|}{ WFJ } & \multirow{2}{*}{$\begin{array}{c}\text { EFJ } \\
\text { Dave Cr. }\end{array}$} \\
\hline & & & WFJ & Pine Cr. & Jack Cr. & \\
\hline \multicolumn{7}{|c|}{ West Fork Jarbidge River (WFJ) - 2006} \\
\hline Jack Creek & $9 / 15 / 2006$ & 0.1 & 0 & 0 & 1 & 0 \\
\hline WFJ downstream of Jack Cr. & 9/15/2006 & 15.0 & 3 & 1 & 1 & 0 \\
\hline \multicolumn{7}{|c|}{ West Fork Jarbidge River (WFJ) - 2007} \\
\hline WFJ at Pine Creek & $7 / 16 / 2007$ & 26.2 & $20^{\mathrm{a}}$ & $8^{\mathrm{b}}$ & 0 & 0 \\
\hline Pine Creek at WFJ & $7 / 16 / 2007$ & 0.1 & 11 & $8^{\mathrm{b}}$ & 0 & 0 \\
\hline Jack Creek & $4 / 18 / 2007$ & 0.1 & 0 & 0 & 7 & 0 \\
\hline WFJ downstream of Jack Cr. & $4 / 28 / 2007$ & 15.0 & 1 & 0 & 2 & 0 \\
\hline WFJ at Forks & $7 / 17 / 2007$ & 0.1 & 0 & 0 & $3^{c}$ & $1^{\mathrm{c}}$ \\
\hline \multicolumn{7}{|c|}{ East Fork Jarbidge River (EFJ) - 2006} \\
\hline EFJ at Murphy Hot Springs & 9/15/2006 & 4.1 & 0 & 0 & 0 & 0 \\
\hline \multicolumn{7}{|c|}{ East Fork Jarbidge River (EFJ) - 2007} \\
\hline Dave Creek & $5 / 23 / 2007$ & 0.4 & 0 & 0 & 0 & 0 \\
\hline EFJ at Murphy Hot Springs & $4 / 28 / 2007$ & 4.1 & 0 & 0 & 1 & 1 \\
\hline EFJ at Forks & 7/17/2007 & 0.1 & 0 & 0 & $2^{\mathrm{c}}$ & $1^{\mathrm{c}}$ \\
\hline Total unique fish - 2006 & & & 3 & 1 & 1 & 0 \\
\hline Total unique fish - 2007 & & & 24 & 9 & 9 & 2 \\
\hline
\end{tabular}

${ }^{\mathrm{z}}$ Eighteen of these 20 fish were interrogated moving downstream. The West Fork Jarbidge River/Pine Cr. PTIS detected a fish on the first day of installation.

${ }^{\mathrm{d}}$ Seven of these 8 fish were interrogated moving out of Pine Creek and downstream in the West Fork Jarbidge River between 7 Oct. 2007 and 4 Nov. 2007.

e One fish from Jack Creek and one from Dave Creek were detected at both the East Fork and West Fork Jarbidge River antennas at the Forks, see figures A2 and A10 for details. 
Table 9. Stream discharge in the Jarbidge River watershed on sampling dates in 2007.

[ Discharge measurements were taken at passive integrated transponder tag interrogation unit (PTIS) sites]

\begin{tabular}{|c|c|c|c|}
\hline \multirow{2}{*}{$\begin{array}{l}\text { Subbasin } \\
\text { Stream and location }\end{array}$} & \multicolumn{3}{|c|}{ Discharge, in cubic feet per second } \\
\hline & $8 / 1 / 07$ & $8 / 13 / 07$ & $8 / 20 / 07$ \\
\hline \multicolumn{4}{|l|}{ West Fork Jarbidge River (WFJ) } \\
\hline Mainstem Jarbidge River below the Forks (rkm 46.6) & 30.75 & not taken & 9.33 \\
\hline WFJ above PTIS (rkm 15.0) & 7.86 & 6.25 & 4.73 \\
\hline Jack Creek below PTIS (rkm 0.1) & 1.39 & 1.07 & 0.77 \\
\hline WFJ below Pine Creek (rkm 26.2) & 5.42 & 3.89 & 3.60 \\
\hline Pine Creek above PTIS (rkm 0.1) & 2.44 & 0.80 & 1.17 \\
\hline \multicolumn{4}{|l|}{ East Fork Jarbidge River (EFJ) } \\
\hline EFJ above PTIS (rkm 4.1) & 18.78 & not taken & 4.84 \\
\hline Dave Creek above PTIS (rkm 0.4) & 0.56 & 0.38 & 0.25 \\
\hline
\end{tabular}




\section{Appendix table and figures}

Appendix Table A1. Temperatures $\left({ }^{\circ} \mathrm{C}\right)$ collected with a hand held thermometer while electrofishing in the upper Jarbidge River subbasin, Nevada, during 2006 and 2007.

[Please see tables 1-4 and figures 2 and 3 for specific location information]

\begin{tabular}{|c|c|c|c|c|}
\hline Site & Date & $\begin{array}{c}\text { Morning } \\
\text { (8:00am-11:30am) }\end{array}$ & $\begin{array}{c}\text { Mid } \\
\text { (11:30am -2:00pm) }\end{array}$ & $\begin{array}{c}\text { Afternoon } \\
\text { (2:00pm-5:00 pm) }\end{array}$ \\
\hline Buck Cr. & 9/14/2007 & 9.0 & & 14.0 \\
\hline \multirow[t]{2}{*}{ Cougar Cr. } & $7 / 11 / 2007$ & 12.5 & & \\
\hline & $7 / 12 / 2007$ & 11.5 & 15.5 & \\
\hline \multirow[t]{10}{*}{ Dave Cr. } & 8/03/2006 & & 14.0 & \\
\hline & $8 / 04 / 2006$ & & 15.0 & \\
\hline & $8 / 05 / 2006$ & 8.0 & 10.0 & \\
\hline & $8 / 06 / 2006$ & 7.0 & 10.5 & \\
\hline & 6/28/2007 & 6.0 & 11.0 & 13.5 \\
\hline & $6 / 29 / 2007$ & 5.0 & 10.5 & 10.0 \\
\hline & 6/30/2007 & 4.0 & 9.0 & 7.0 \\
\hline & $7 / 01 / 2007$ & 9.0 & 11.5 & \\
\hline & $7 / 02 / 2007$ & 7.5 & 13.0 & 14.0 \\
\hline & $9 / 06 / 2007$ & 6.5 & 9.0 & 12.0 \\
\hline \multicolumn{4}{|l|}{ East Fork Jarbidge } & \\
\hline \multirow[t]{6}{*}{ River } & $8 / 17 / 2006$ & & 11.5 & 14.0 \\
\hline & 8/18/2006 & 9.5 & & 13.0 \\
\hline & 8/19/2006 & & 10.0 & 9.5 \\
\hline & $7 / 12 / 2007$ & 9.0 & & 12.0 \\
\hline & $7 / 13 / 2007$ & 9.0 & 14.0 & 15.0 \\
\hline & $7 / 14 / 2007$ & & 15.0 & \\
\hline \multirow[t]{2}{*}{ Fall Cr. } & 8/20/2006 & 8.0 & 9.5 & \\
\hline & $7 / 15 / 2007$ & & & 13.0 \\
\hline Gods Pocket Cr. & $7 / 17 / 2007$ & 10.5 & & \\
\hline \multirow[t]{10}{*}{ Jack Cr. } & $9 / 08 / 2006$ & 9.0 & & \\
\hline & $9 / 09 / 2006$ & 9.0 & 10.0 & 9.5 \\
\hline & $9 / 11 / 2006$ & & 8.0 & \\
\hline & 8/06/2007 & 13.0 & 13.5 & \\
\hline & 8/07/2007 & 10.5 & 10.5 & 12.0 \\
\hline & 8/08/2007 & 10.0 & & 12.5 \\
\hline & 8/09/2007 & 11.0 & 13.0 & 16.0 \\
\hline & 8/09/2007 & 11.0 & & \\
\hline & 8/10/2007 & 11.5 & & 14.5 \\
\hline & $9 / 11 / 2007$ & 6.0 & 7.0 & \\
\hline \multirow[t]{4}{*}{ Pine Cr. } & $7 / 23 / 2006$ & & 13.5 & 14.5 \\
\hline & $7 / 24 / 2006$ & 11.0 & 11.5 & \\
\hline & $7 / 25 / 2006$ & 10.0 & 12.5 & \\
\hline & $7 / 26 / 2006$ & & 14.0 & \\
\hline Pine Cr. & $8 / 21 / 2007$ & 11.0 & 12.0 & \\
\hline
\end{tabular}




\begin{tabular}{|c|c|c|c|c|}
\hline Site & Date & $\begin{array}{c}\text { Morning } \\
\text { (8:00am-11:30am) }\end{array}$ & $\begin{array}{c}\text { Mid } \\
\text { (11:30am -2:00pm) }\end{array}$ & $\begin{array}{c}\text { Afternoon } \\
\text { (2:00pm-5:00 pm) }\end{array}$ \\
\hline \multirow{7}{*}{ Slide Cr. } & $8 / 22 / 2007$ & & 11.5 & 13.5 \\
\hline & 8/23/2007 & 8.0 & 10.5 & 12.5 \\
\hline & 8/27/2007 & 10.0 & & 14.5 \\
\hline & 8/29/2007 & 10.0 & 12.0 & 14.0 \\
\hline & 8/21/2006 & & & 12.0 \\
\hline & 8/22/2006 & 8.0 & 9.5 & \\
\hline & 7/16/2007 & 12.0 & 13.0 & 14.0 \\
\hline \multicolumn{5}{|c|}{ West Fork Jarbidge } \\
\hline \multirow[t]{20}{*}{ River } & 7/19/2006 & & 12.0 & \\
\hline & 7/20/2006 & 10.0 & 12.5 & \\
\hline & 7/21/2006 & 9.5 & 12.5 & \\
\hline & $7 / 22 / 2006$ & 10.0 & 12.0 & 12.5 \\
\hline & 8/07/2006 & 10.0 & 11.5 & \\
\hline & 9/23/2006 & & 8.0 & \\
\hline & 9/24/2006 & & 7.0 & \\
\hline & 9/25/2006 & 5.0 & 7.0 & \\
\hline & $10 / 04 / 2006$ & 6.0 & & \\
\hline & 6/11/2007 & & 10.0 & \\
\hline & 6/13/2007 & 7.5 & 12.0 & \\
\hline & 6/14/2007 & & 9.5 & 13.0 \\
\hline & 6/20/2007 & 7.0 & 8.0 & \\
\hline & 6/21/2007 & 6.0 & 8.5 & \\
\hline & 6/22/2007 & 6.5 & 8.0 & 9.0 \\
\hline & 6/26/2007 & 5.0 & 10.0 & 12.0 \\
\hline & 6/27/2007 & 6.0 & 14.0 & 12.5 \\
\hline & 8/02/2007 & 14.0 & & 16.0 \\
\hline & 8/14/2007 & 11.0 & 13.0 & \\
\hline & $8 / 15 / 2007$ & 10.5 & 11.0 & \\
\hline
\end{tabular}


Appendix Figures A1 - A50. Maps of tagging location and the timing and location of detection or recapture for all bull trout with noteworthy movements during 2006 and 2007 in the Jarbidge River subbasin, Nevada and Idaho. 

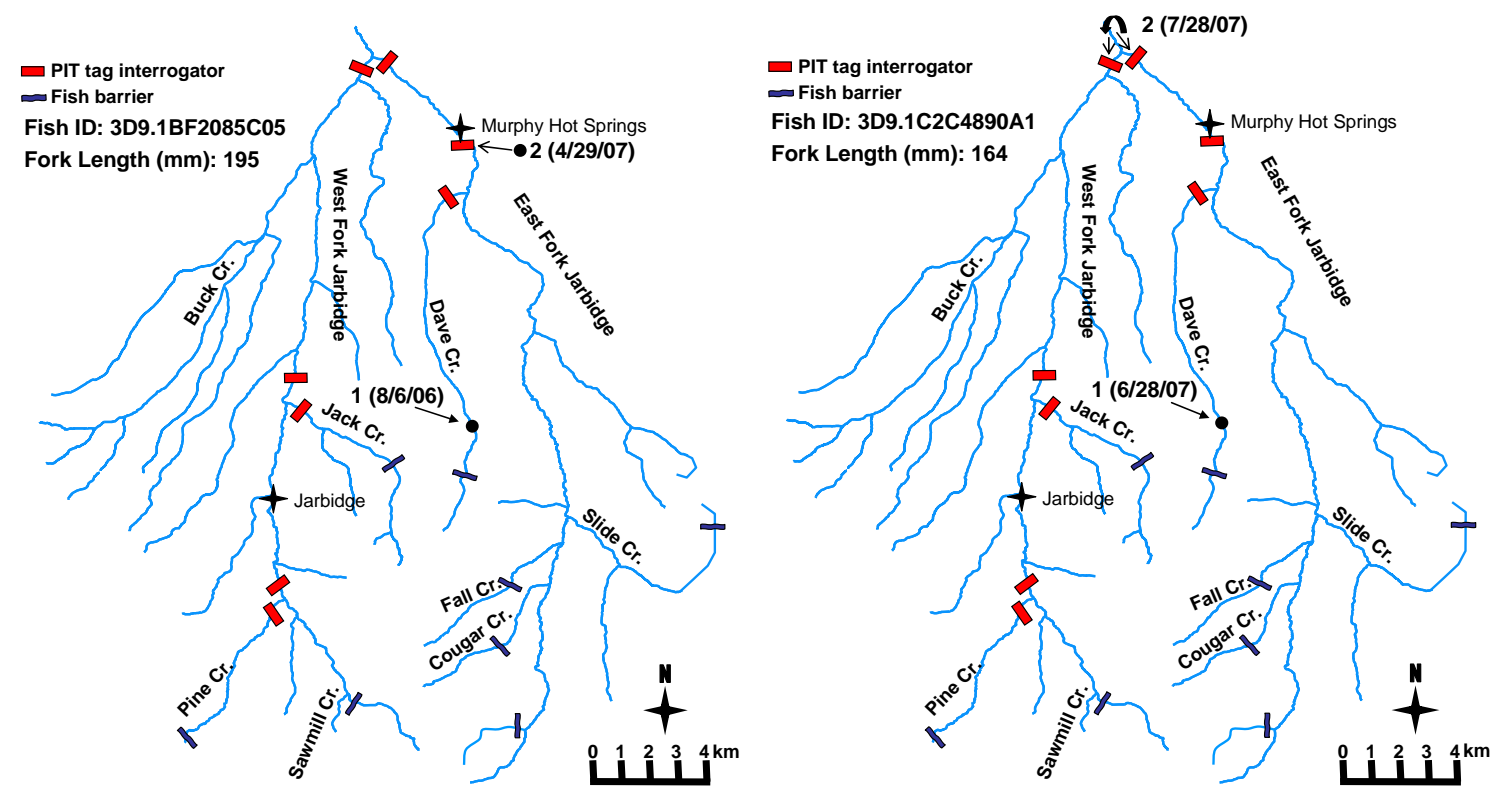

A1

A2

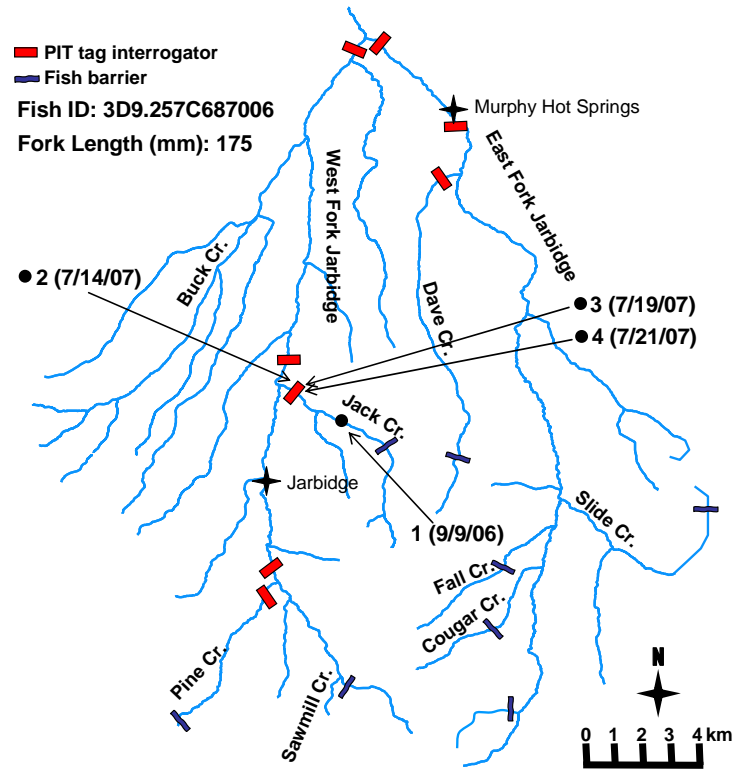

A4

Figures A1 - A4. Movement of PIT-tagged bull trout within the Jarbidge River subbasin in 2006 and 2007. Each map represents a single bull trout and the number next to the symbol represents the order of events ( 1 = tagging, 2 = interrogation or recapture, $3+=$ subsequent interrogation or recapture). See table 8 and figures 28 and 29 for installation dates and summaries of interrogation information. 

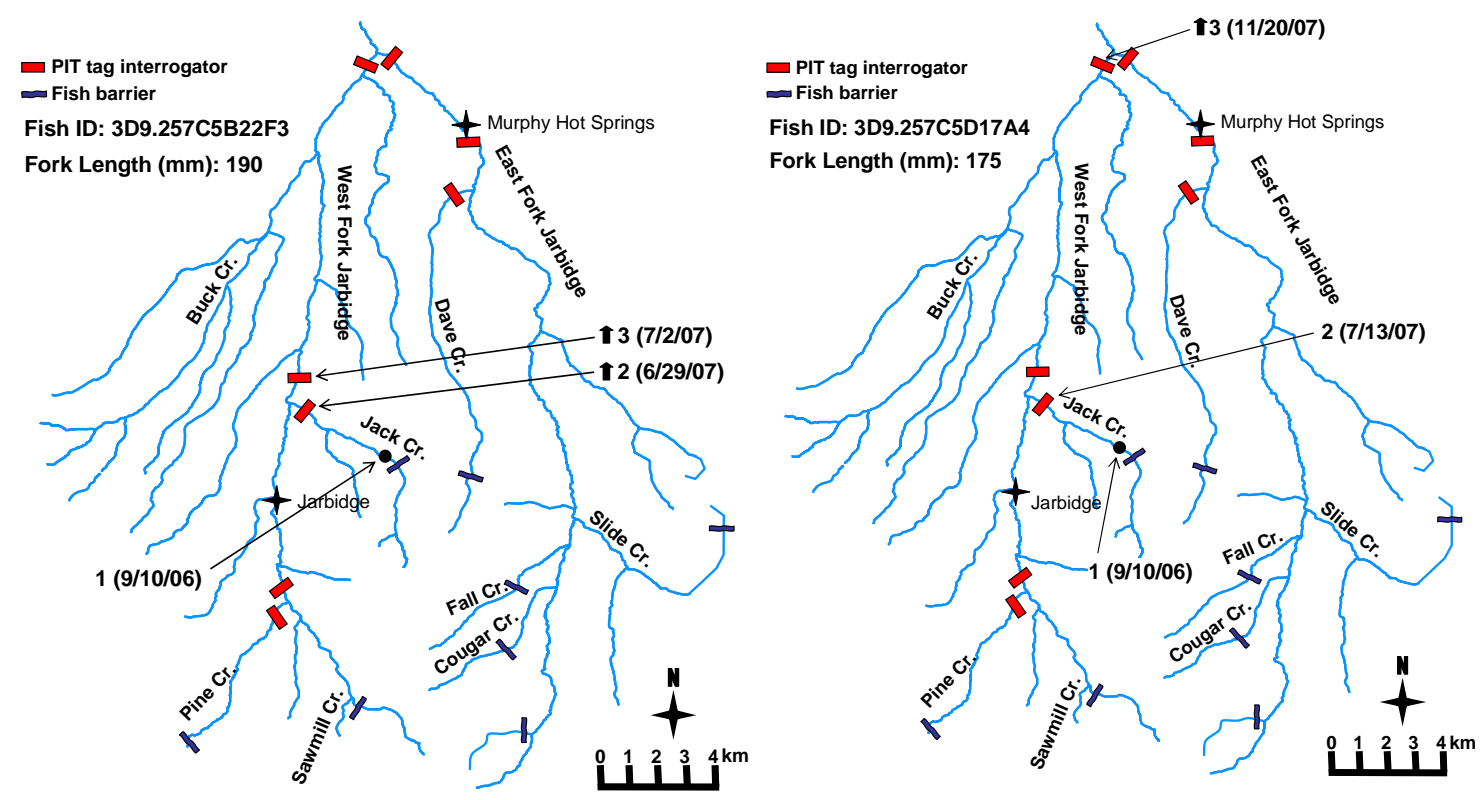

A5

A6
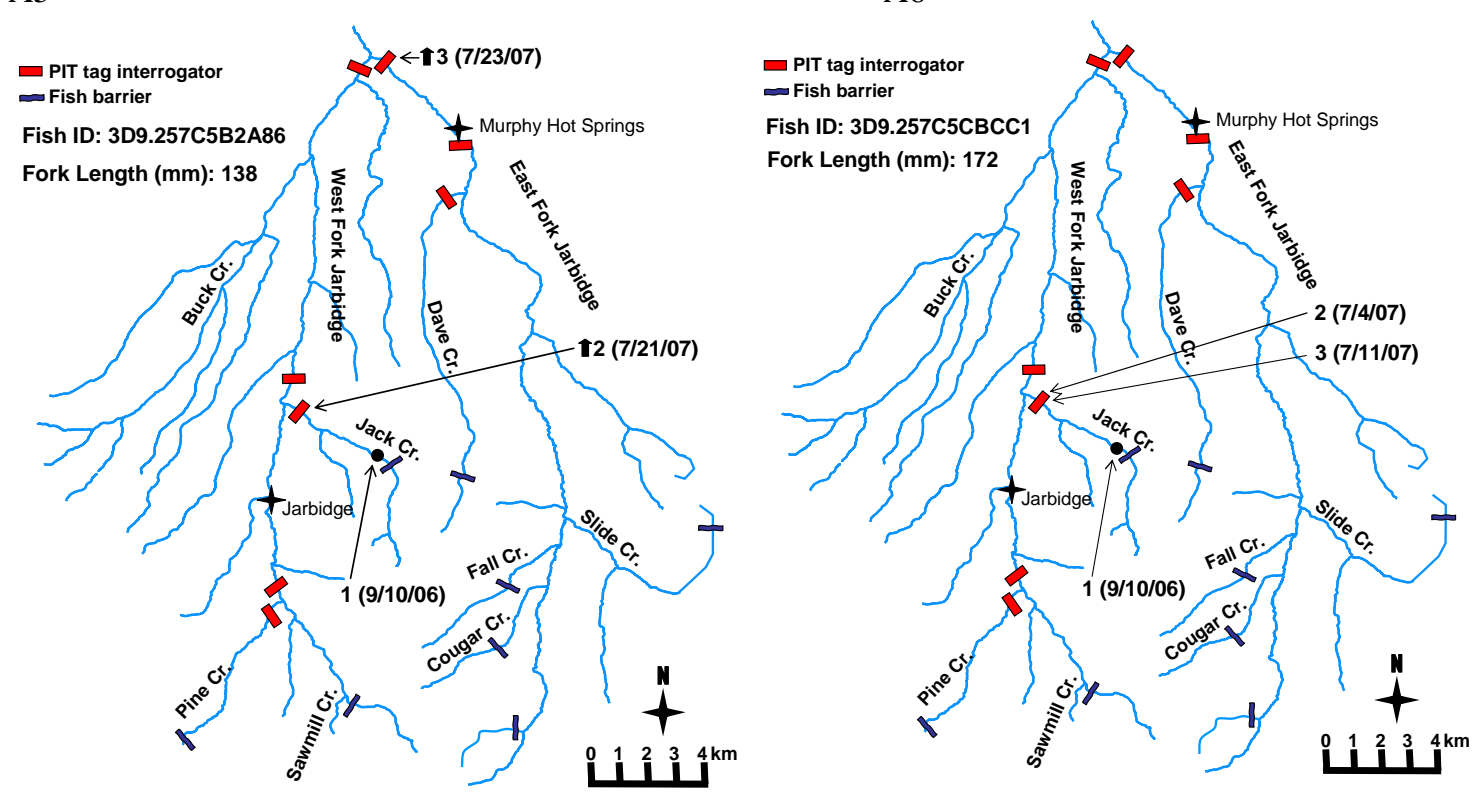

A8

Figures A5 - A8. Movement of PIT-tagged bull trout within the Jarbidge River subbasin in 2006 and 2007. Each map represents a single bull trout and the number next to the symbol represents the order of events ( $1=$ tagging, 2 = interrogation or recapture, $3+=$ subsequent interrogation or recapture). See table 8 and figures 28 and 29 for installation dates and summaries of interrogation information. 

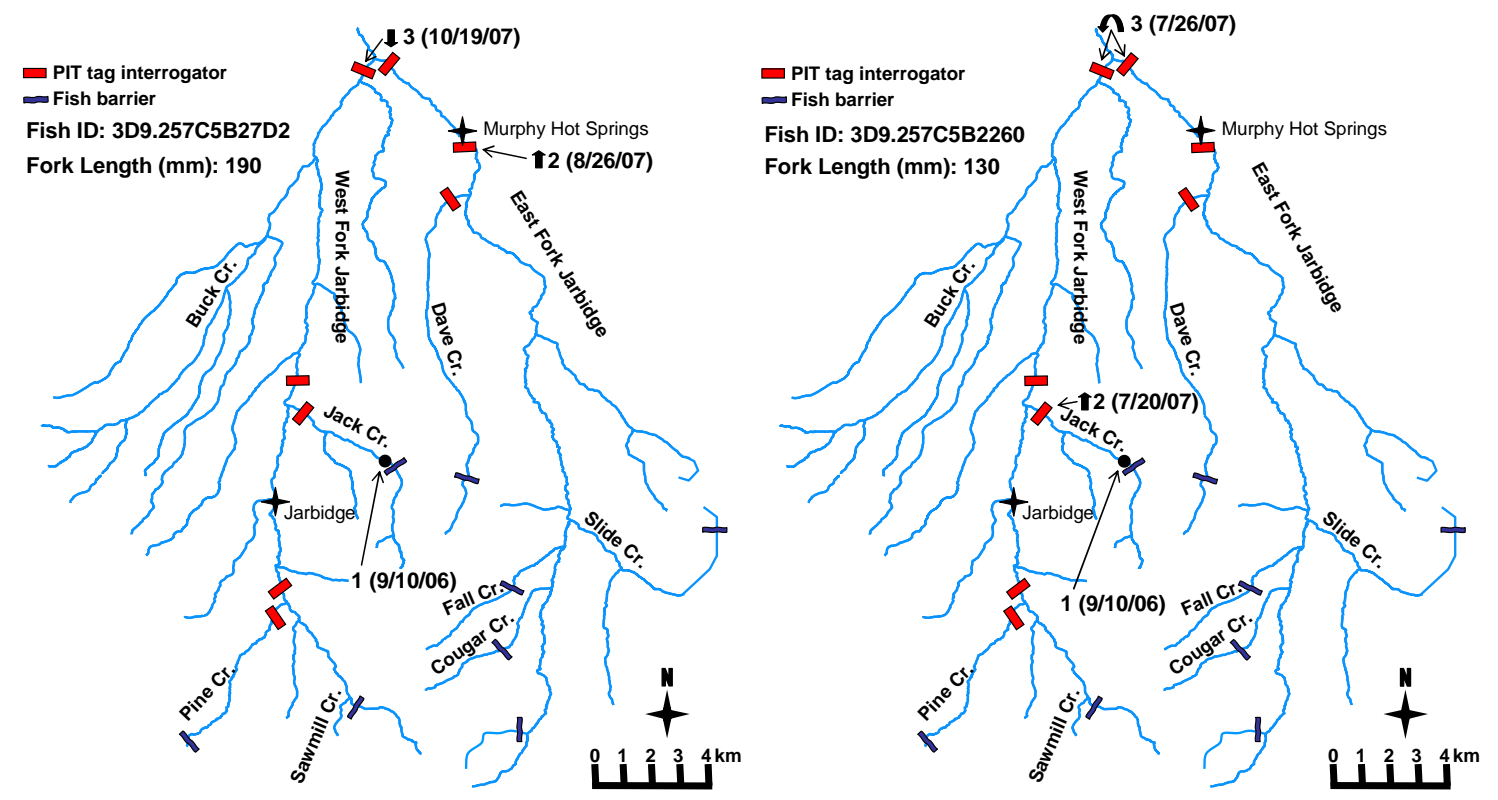

A9

A10
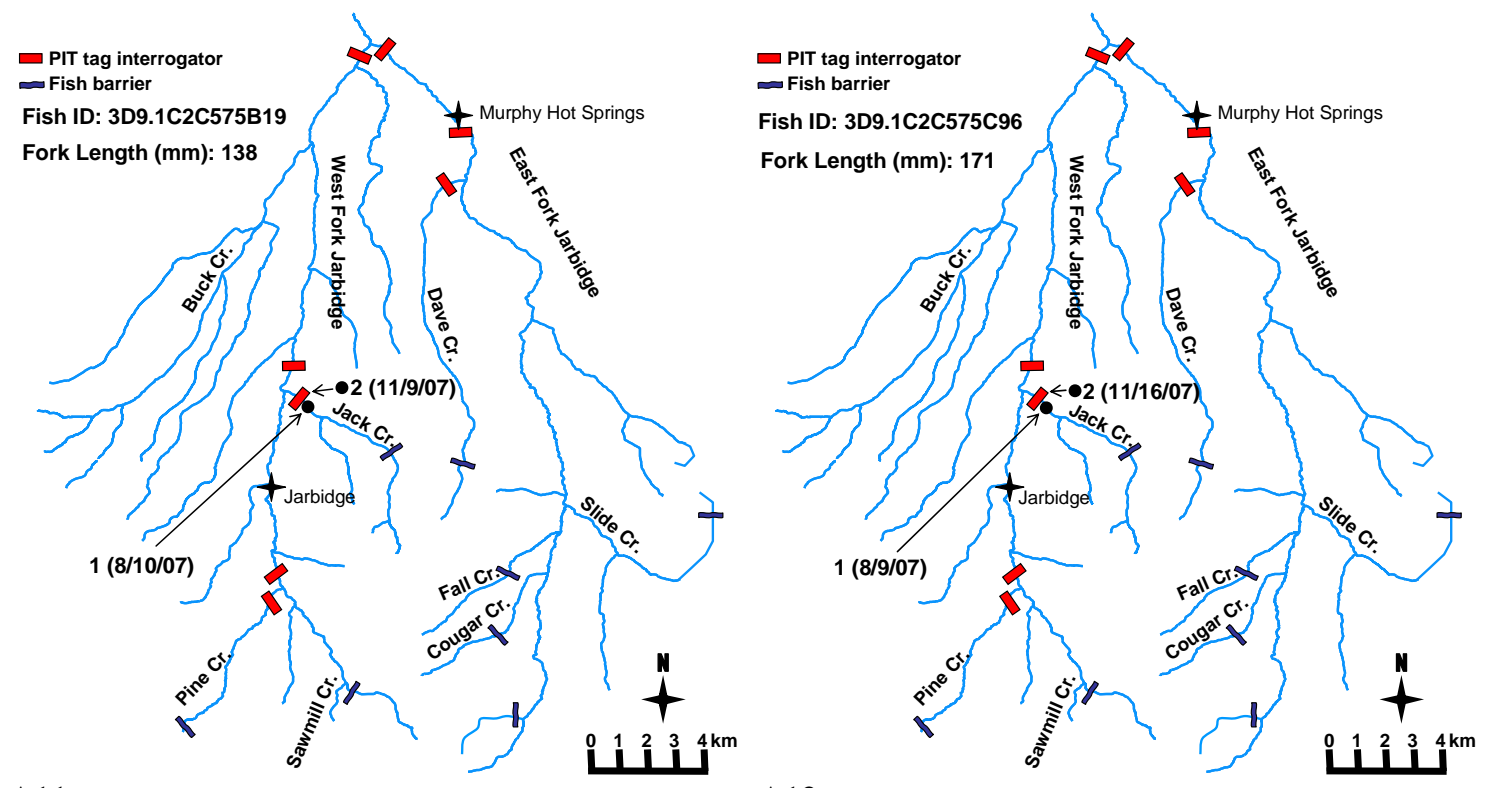

A12

Figures A9 - A12. Movement of PIT-tagged bull trout within the Jarbidge River subbasin in 2006 and 2007. Each map represents a single bull trout and the number next to the symbol represents the order of events ( $1=$ tagging, $2=$ interrogation or recapture, $3+=$ subsequent interrogation or recapture). See table 8 and figures 28 and 29 for installation dates and summaries of interrogation information. 

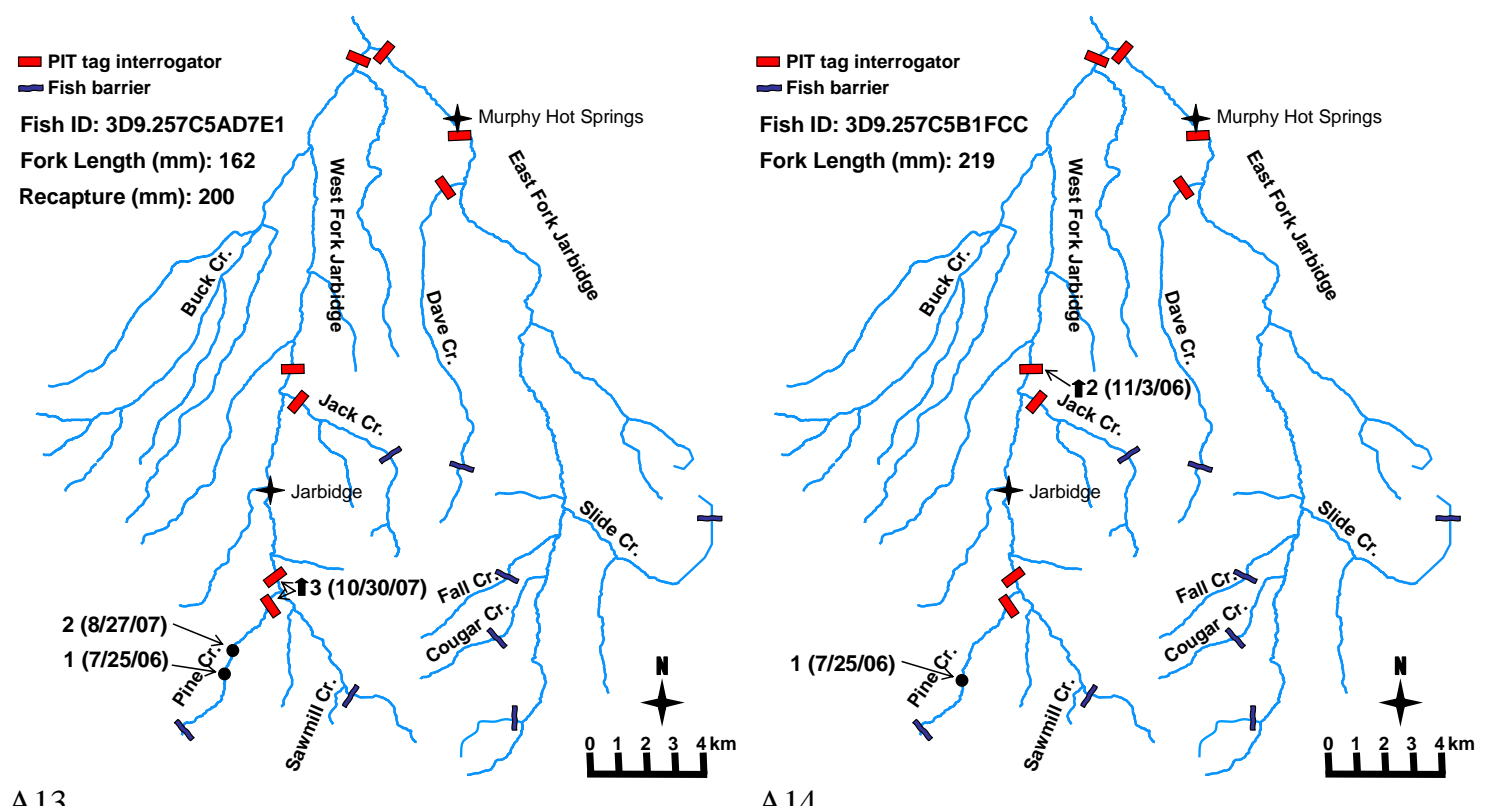

A13

\section{A14}
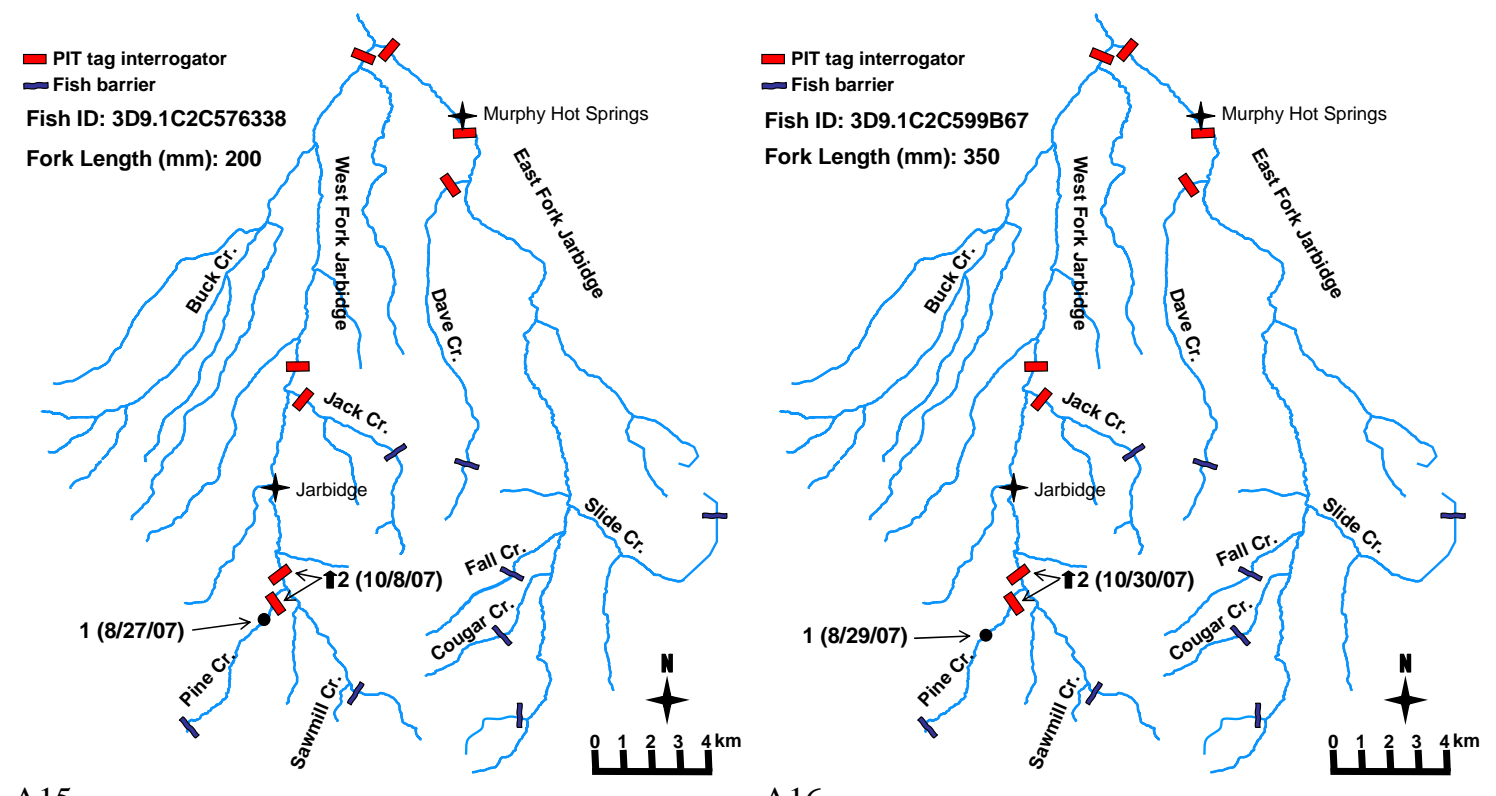

A16

Figures A13 - A16. Movement of PIT-tagged bull trout within the Jarbidge River subbasin in 2006 and 2007. Each map represents a single bull trout and the number next to the symbol represents the order of events ( 1 = tagging, 2 = interrogation or recapture, $3+=$ subsequent interrogation or recapture). See table 8 and figures 28 and 29 for installation dates and summaries of interrogation information. 

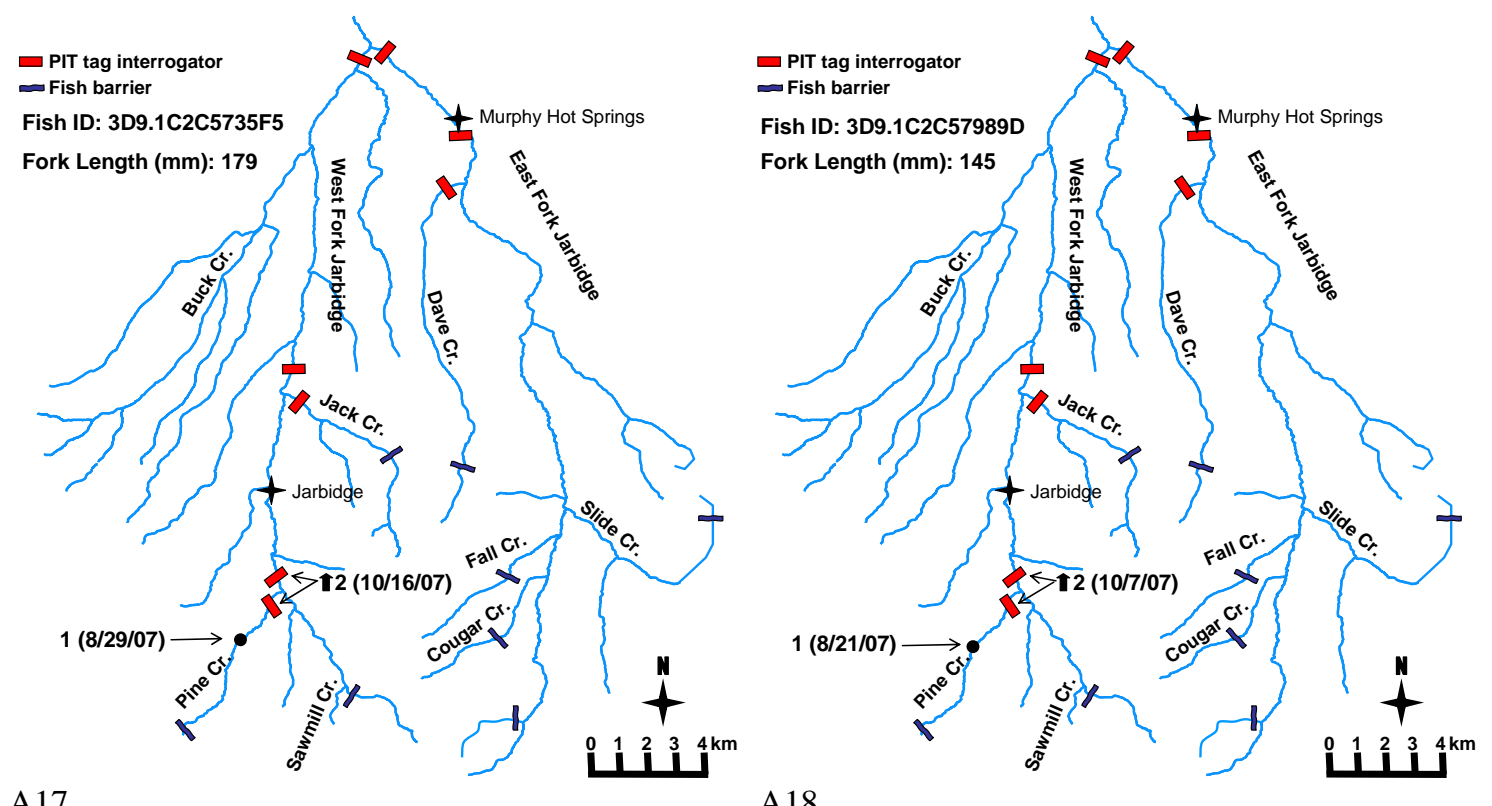

A17

\section{A18}
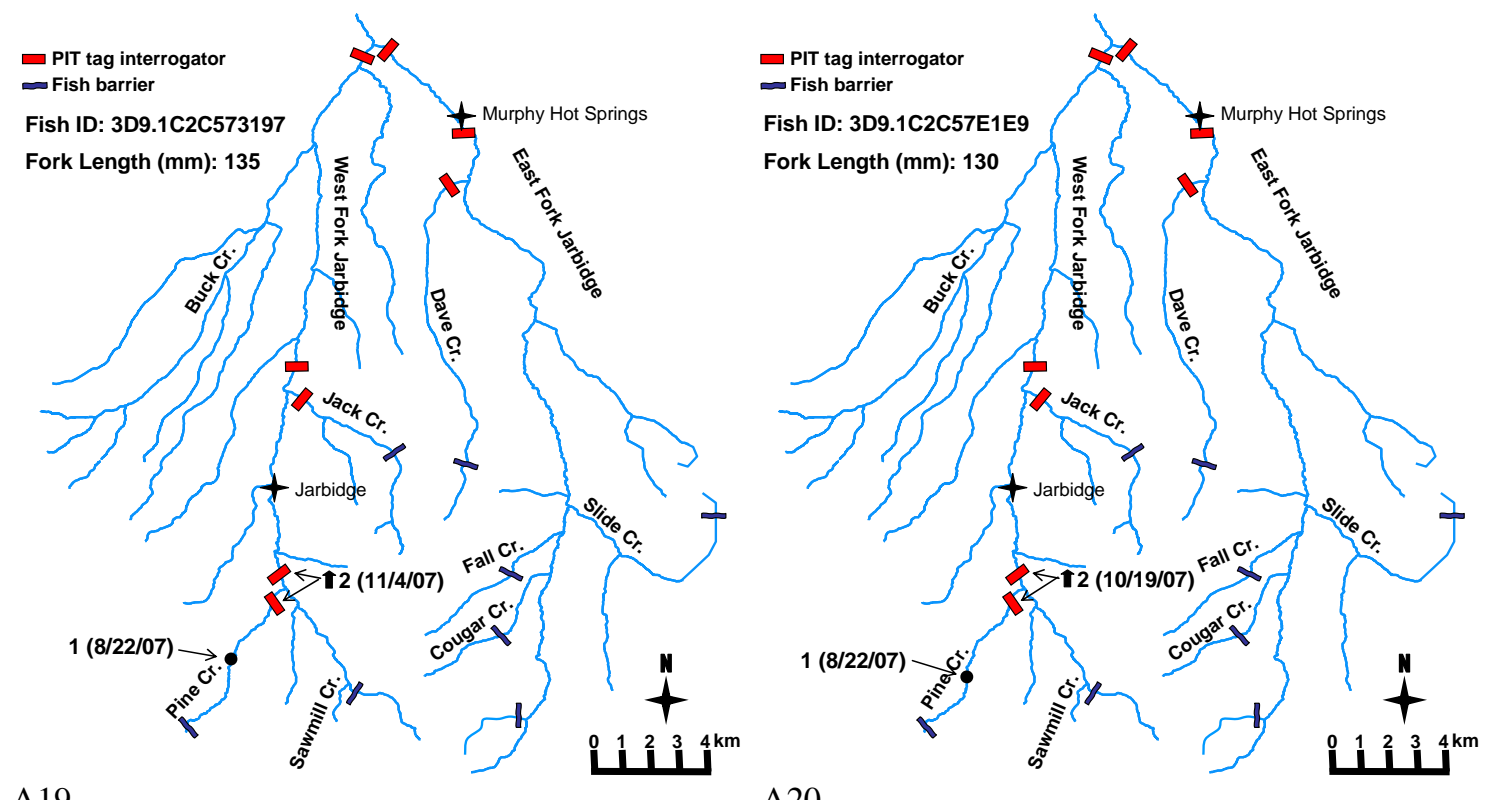

A20

Figures A17 - A20. Movement of PIT-tagged bull within the Jarbidge River subbasin in 2006 and 2007. Each map represents a single bull trout and the number next to the symbol represents the order of events ( 1 = tagging, 2 = interrogation or recapture, $3+=$ subsequent interrogation or recapture). See table 8 and figures 28 and 29 for installation dates and summaries of interrogation information. 

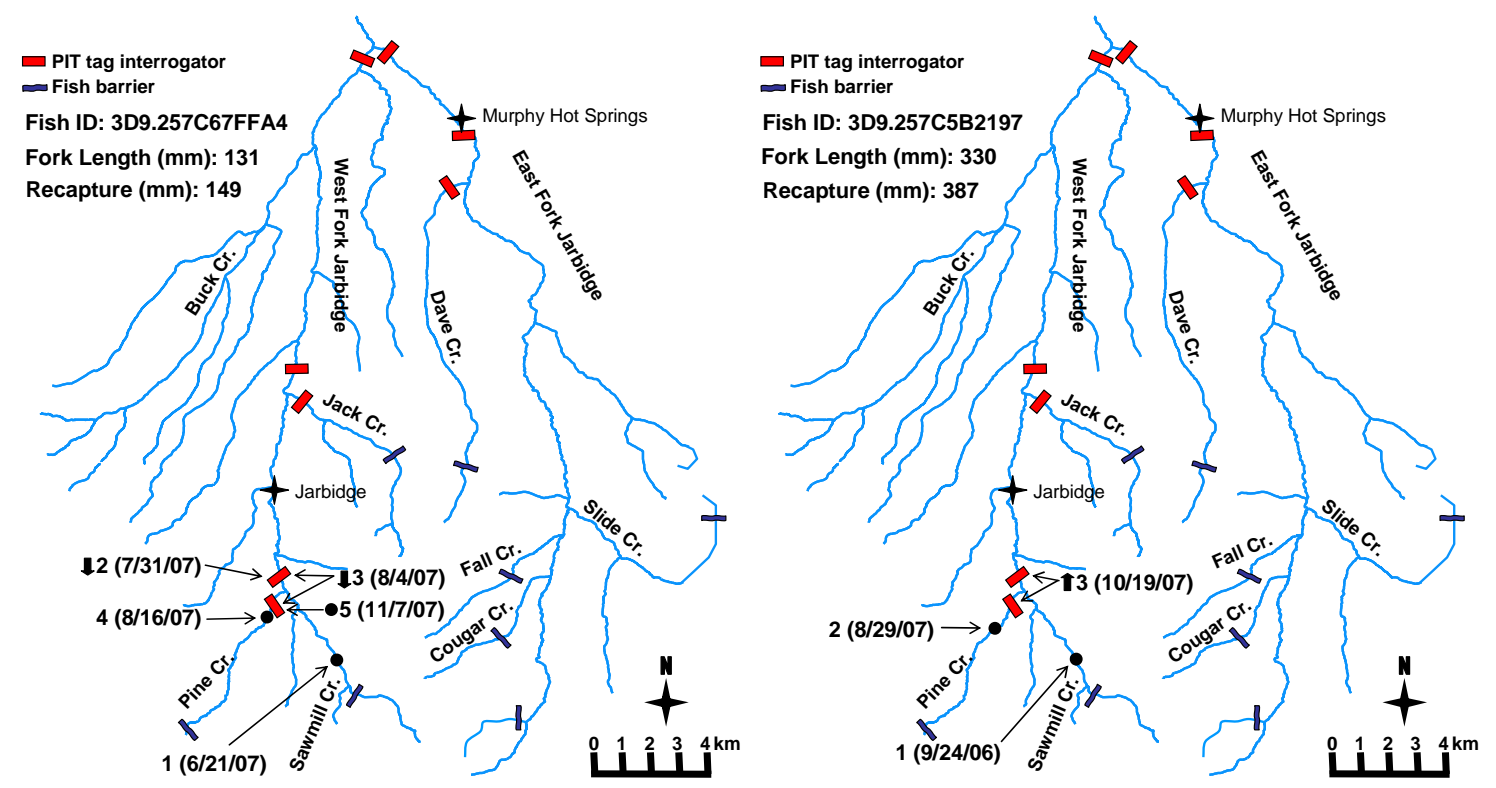

A21

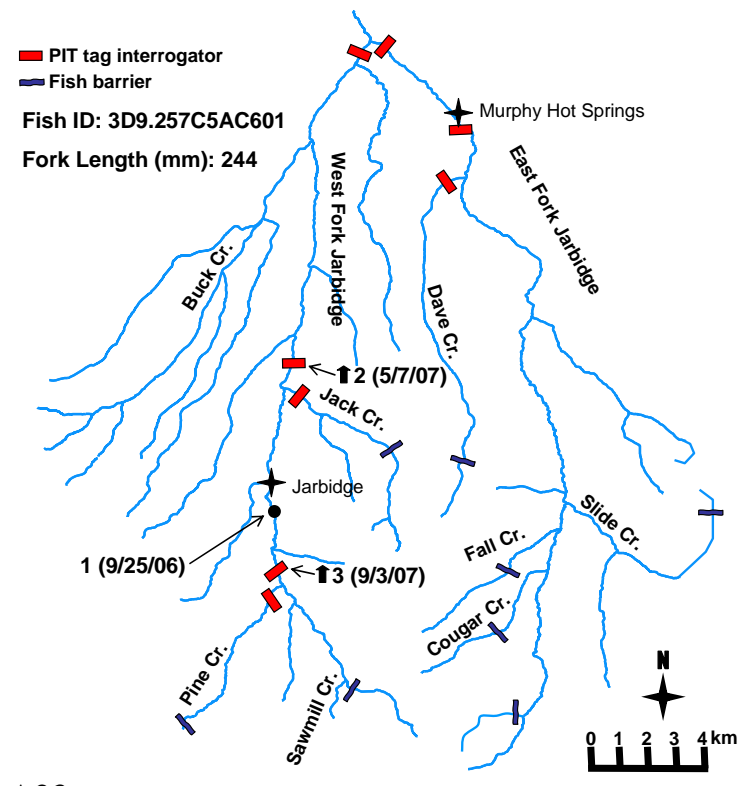

A23
A22

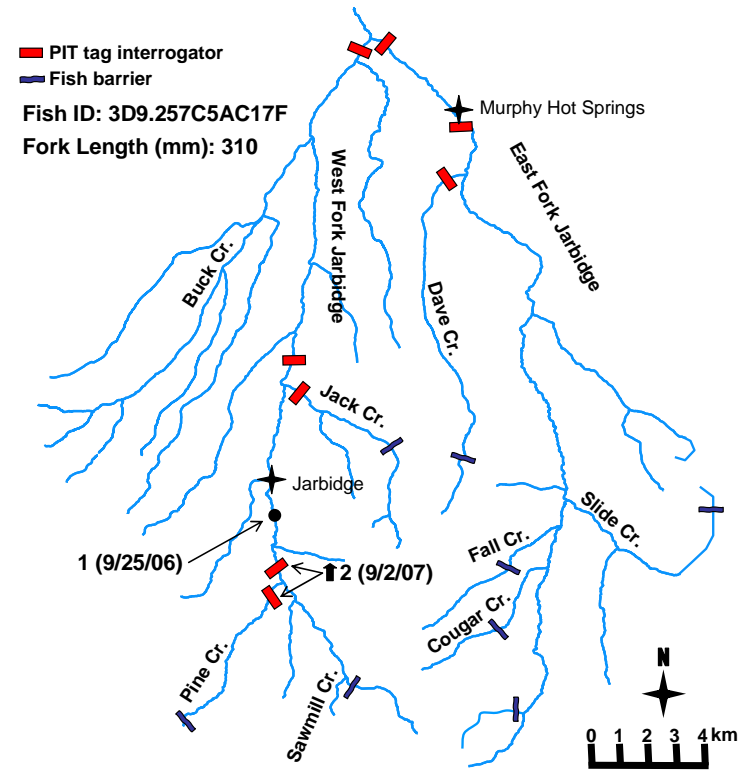

A24

Figures A21 - A24. Movement of PIT-tagged bull trout within the Jarbidge River subbasin in 2006 and 2007. Each map represents a single bull trout and the number next to the symbol represents the order of events ( $1=$ tagging, $2=$ interrogation or recapture, $3+=$ subsequent interrogation or recapture). See table 8 and figures 28 and 29 for installation dates and summaries of interrogation information. 

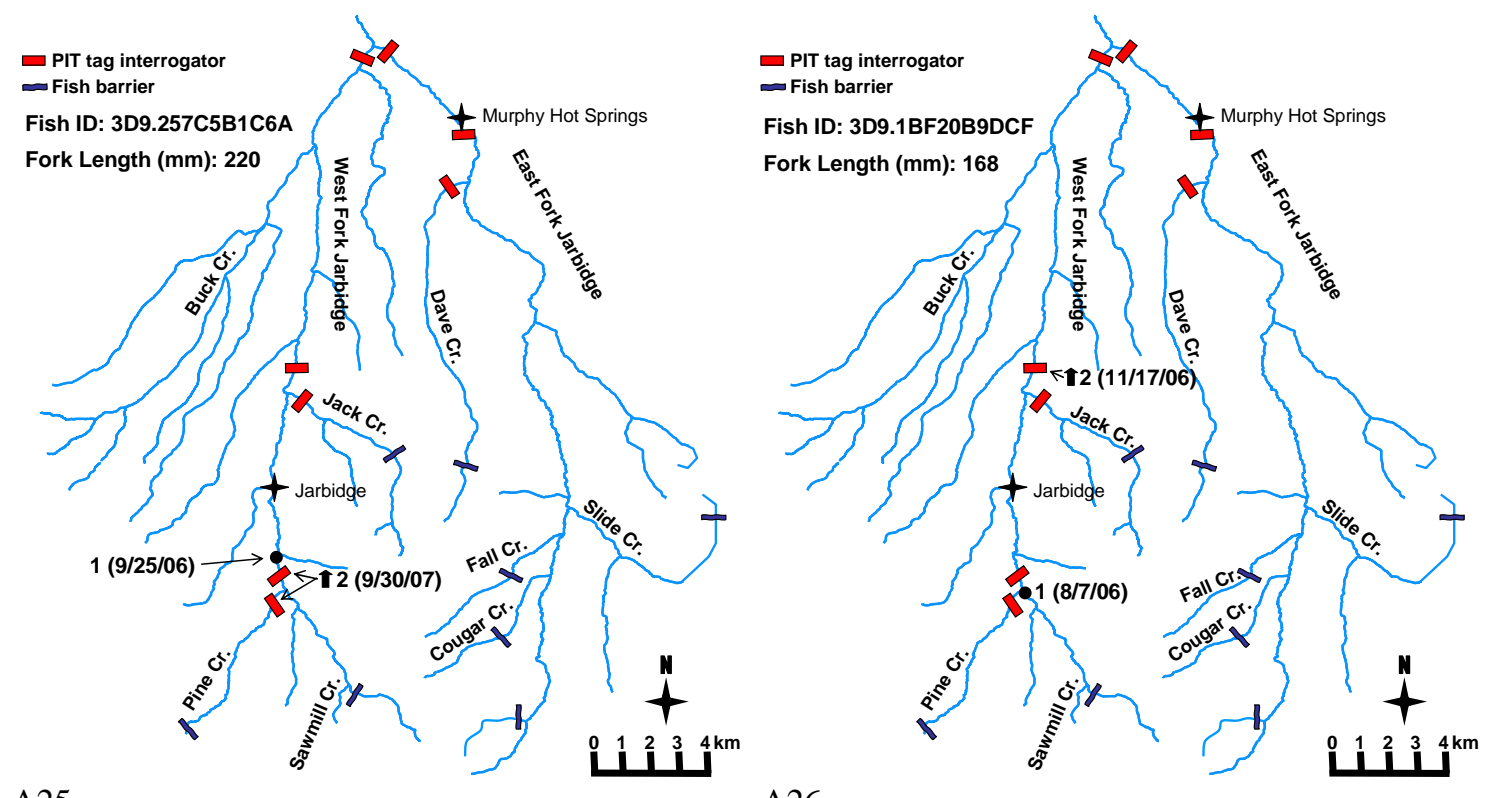

A25

\section{A26}

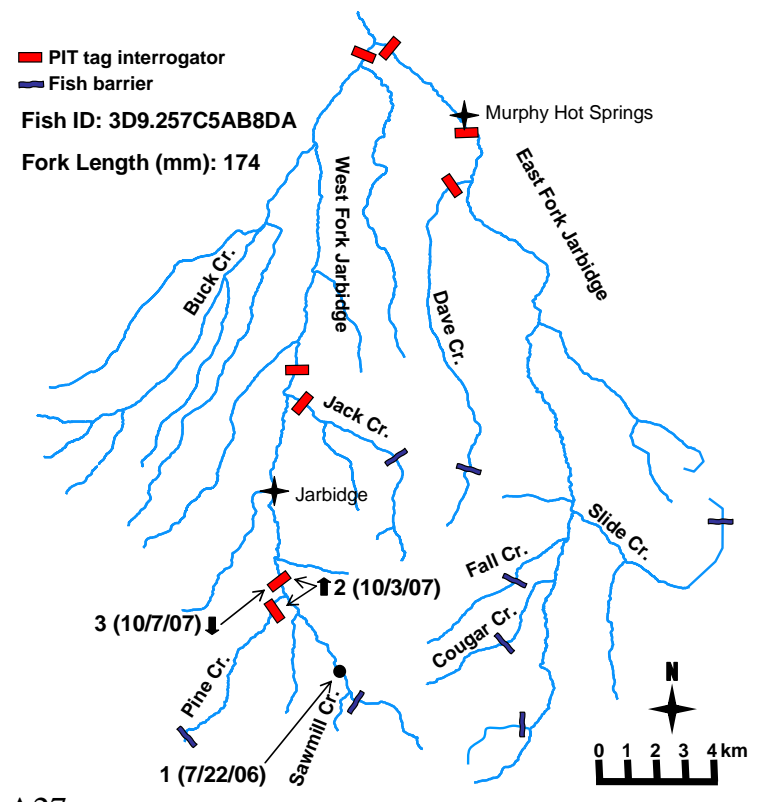

A27

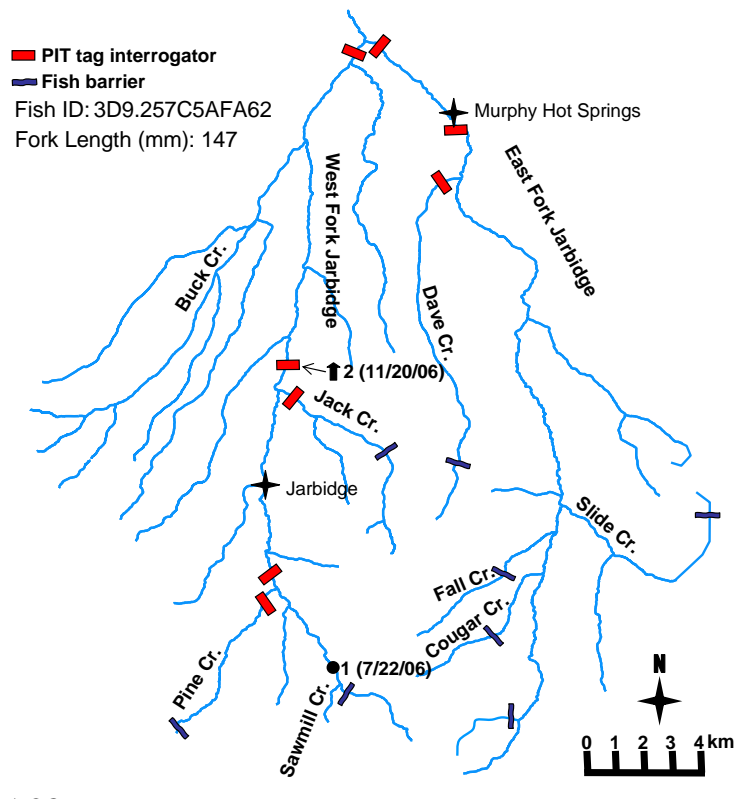

A28

Figures A25 - A28. Movement of PIT-tagged bull within the Jarbidge River subbasin in 2006 and 2007. Each map represents a single bull trout and the number next to the symbol represents the order of events ( 1 = tagging, 2 = interrogation or recapture, $3+=$ subsequent interrogation or recapture). See table 8 and figures 28 and 29 for installation dates and summaries of interrogation information. 

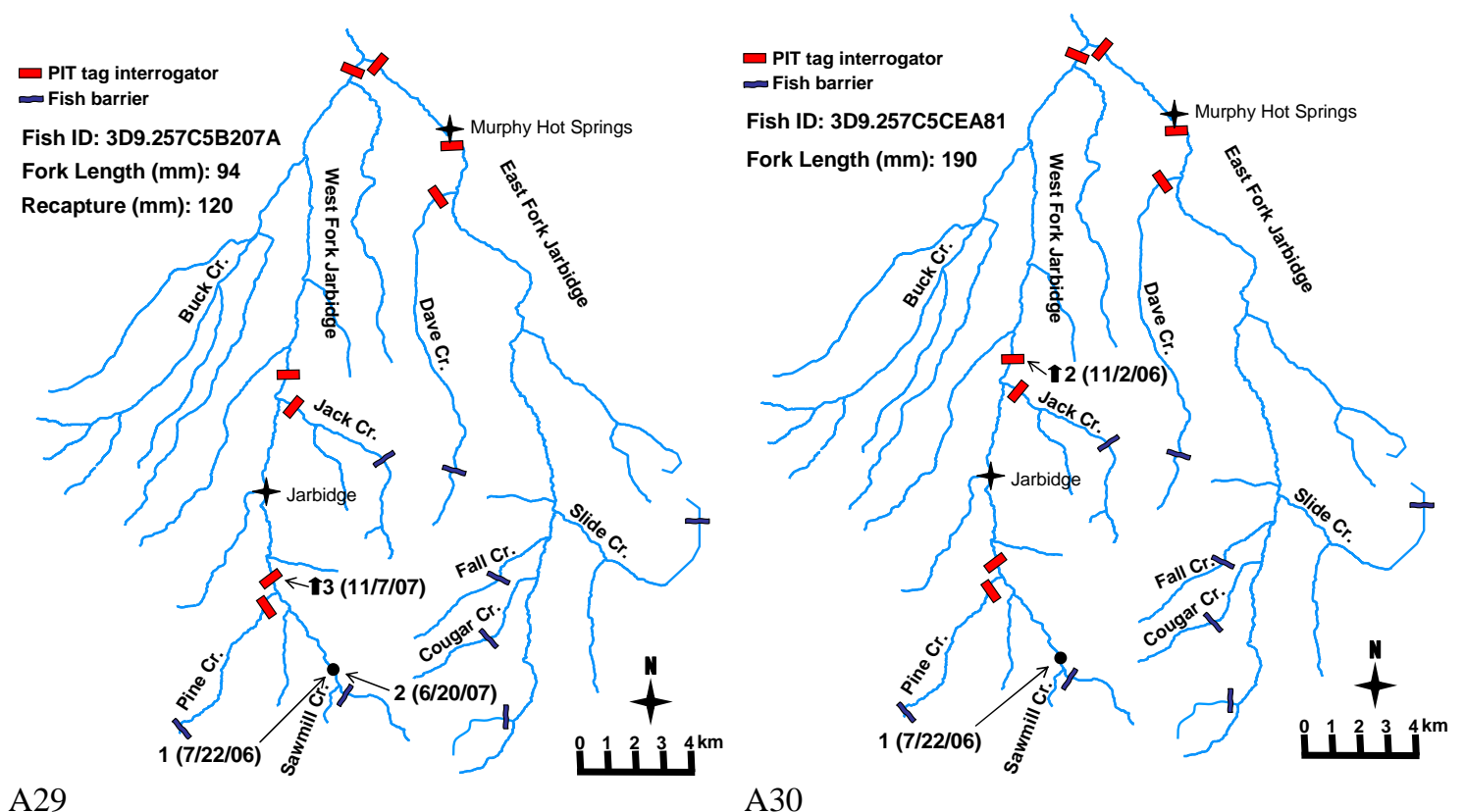

A30
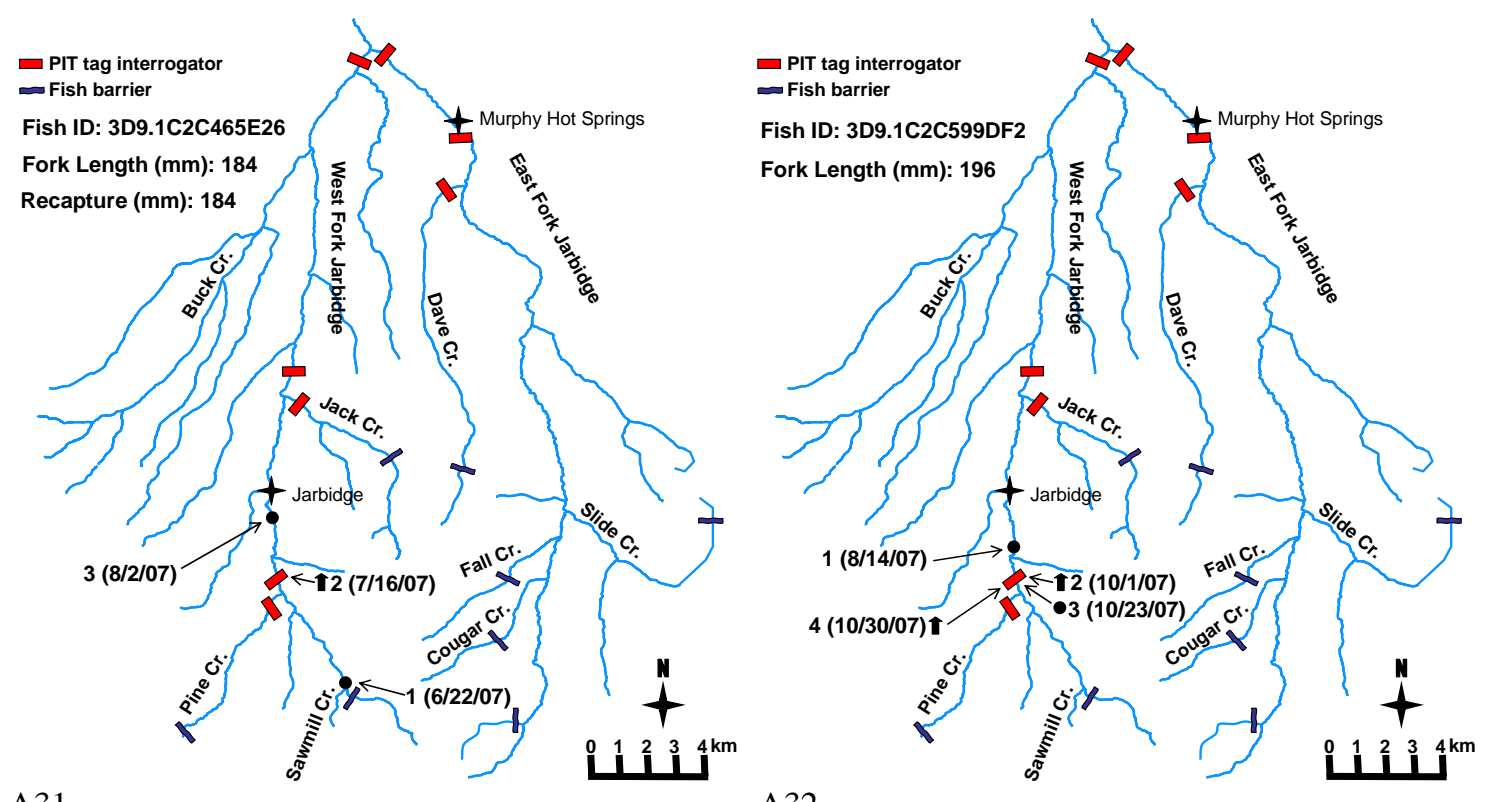

A31

A32

Figures A29 - A32. Movement of PIT-tagged bull trout within the Jarbidge River subbasin in 2006 and 2007. Each map represents a single bull trout and the number next to the symbol represents the order of events ( 1 = tagging, 2 = interrogation or recapture, $3+=$ subsequent interrogation or recapture). See table 8 and figures 28 and 29 for installation dates and summaries of interrogation information. 

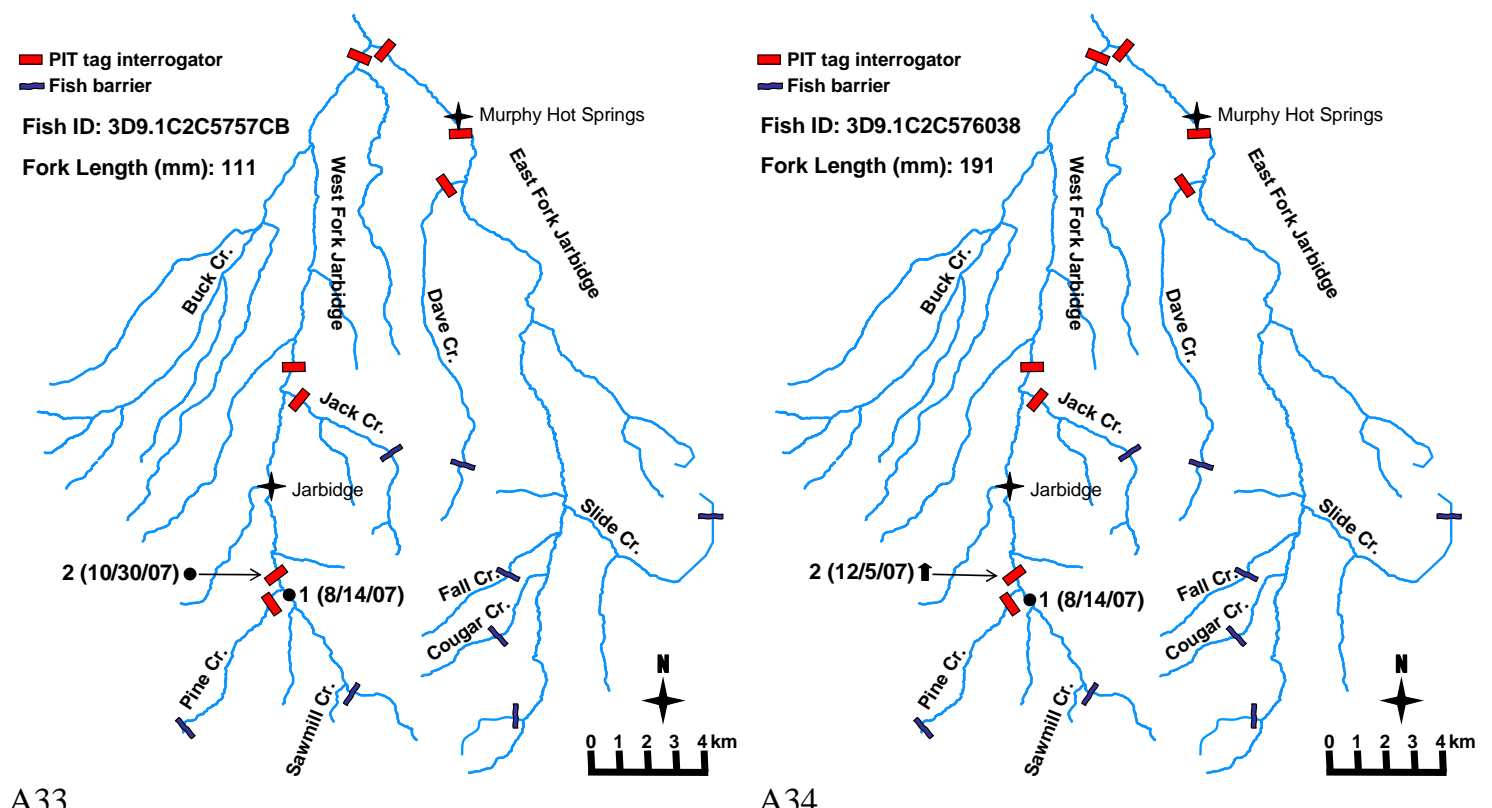

A34
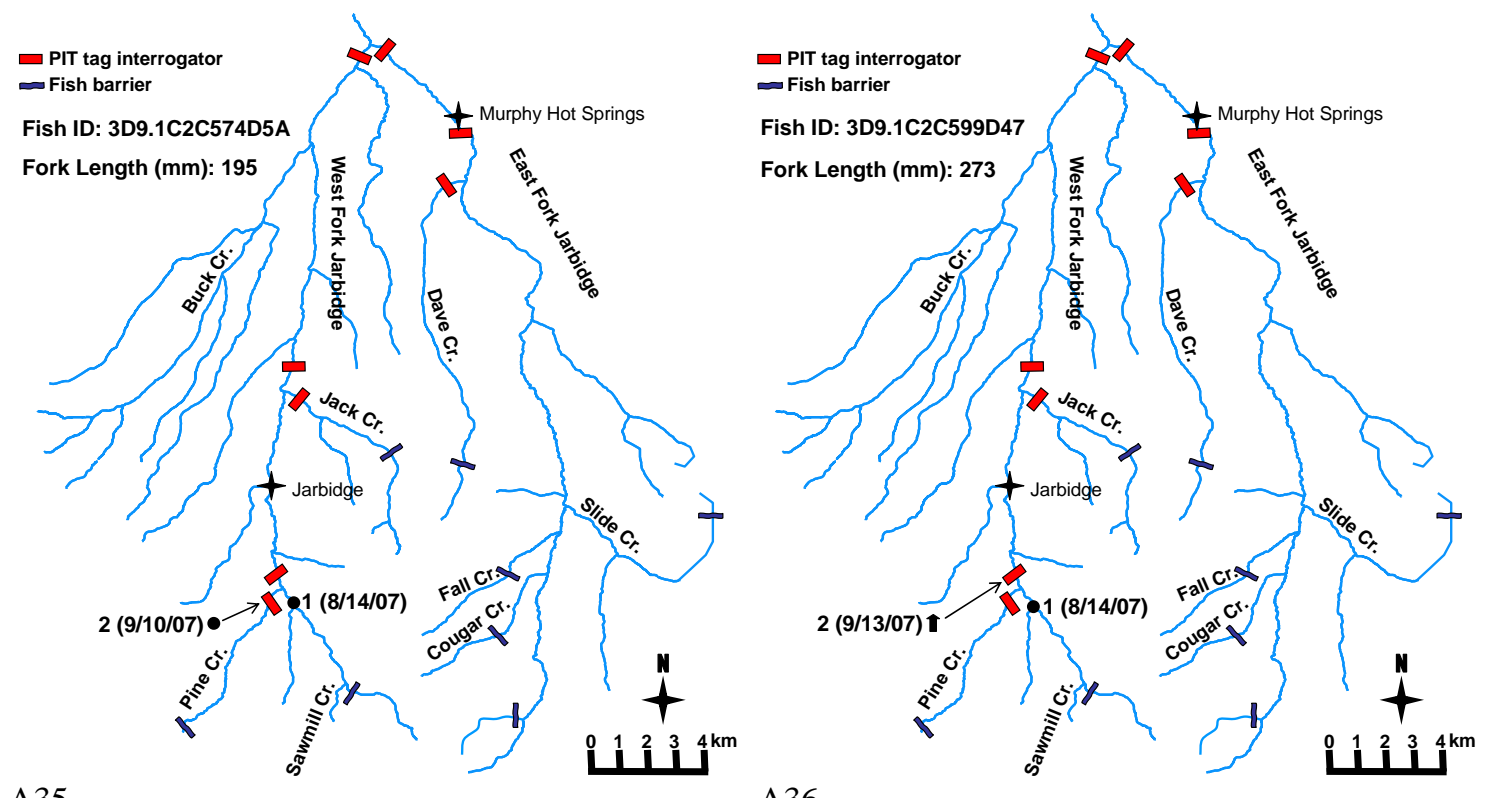

A35

A36

Figures A33 - A36. Movement of PIT-tagged bull trout within the Jarbidge River subbasin in 2006 and 2007. Each map represents a single bull trout and the number next to the symbol represents the order of events ( 1 = tagging, 2 = interrogation or recapture, $3+=$ subsequent interrogation or recapture). See table 8 and figures 28 and 29 for installation dates and summaries of interrogation information. 

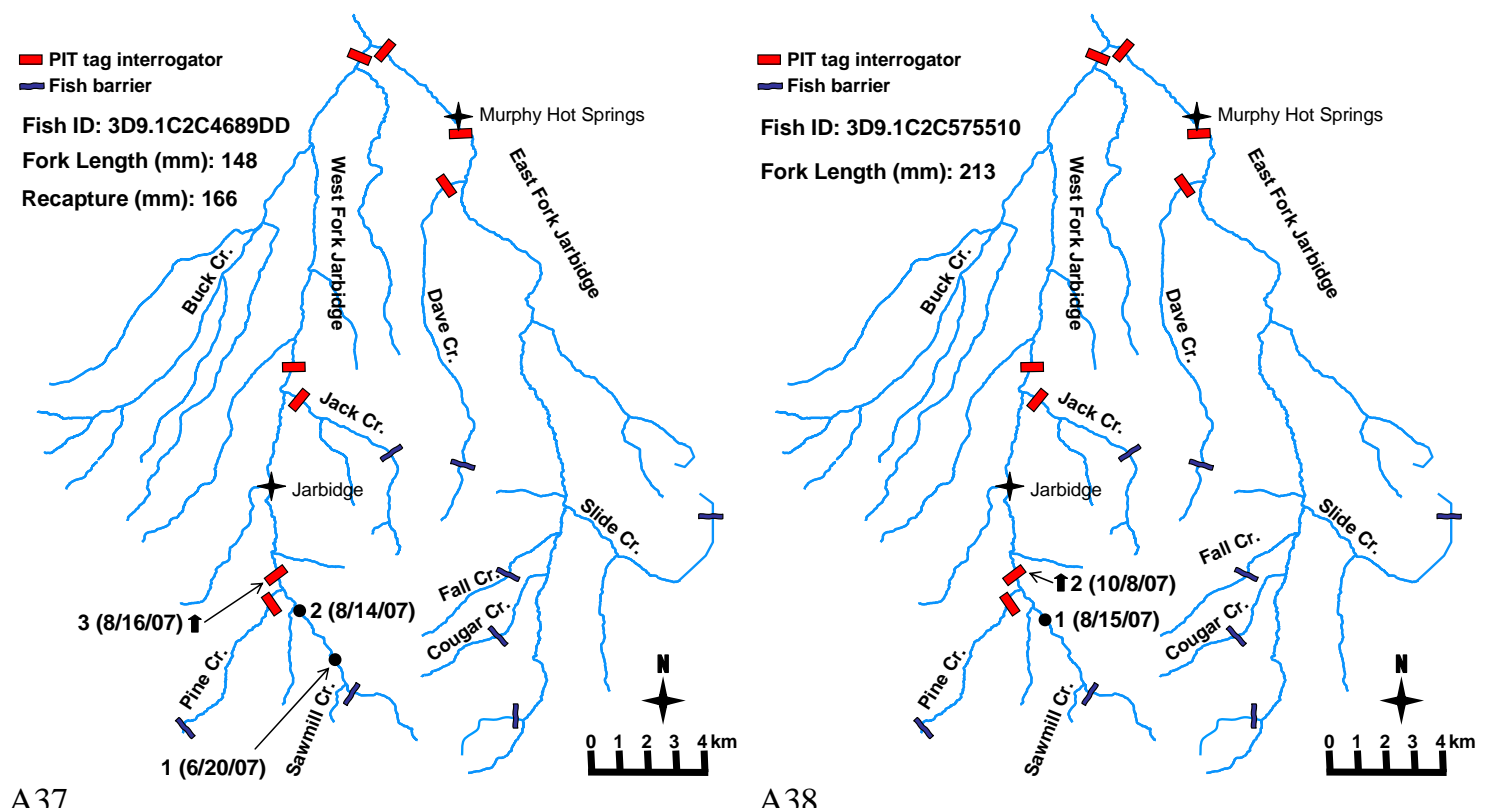

A38
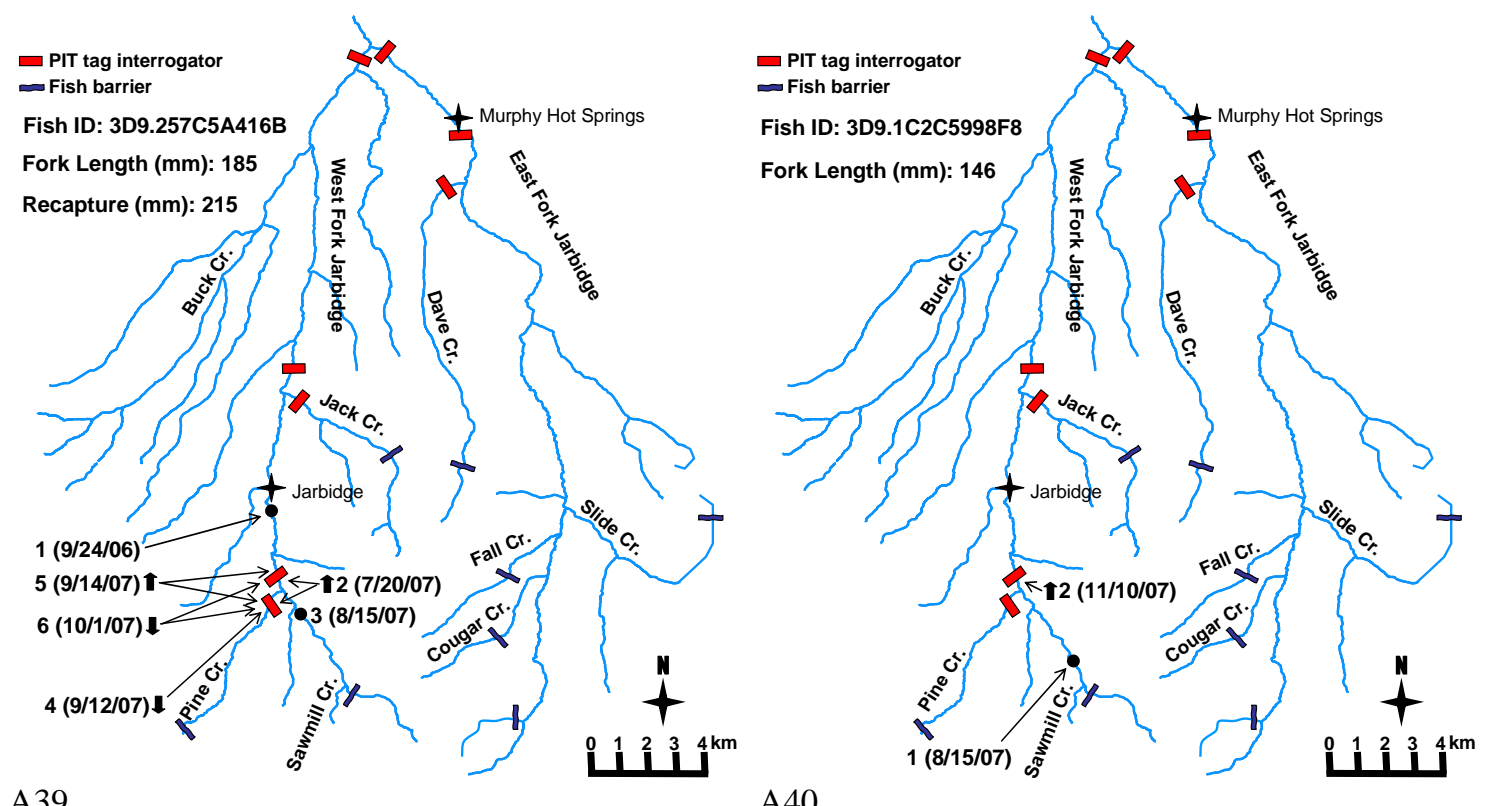

A39

A40

Figures A37 - A40. Movement of PIT-tagged bull trout within the Jarbidge River subbasin in 2006 and 2007. Each map represents a single bull trout and the number next to the symbol represents the order of events ( 1 = tagging, 2 = interrogation or recapture, $3+=$ subsequent interrogation or recapture). See table 8 and figures 28 and 29 for installation dates and summaries of interrogation information. 

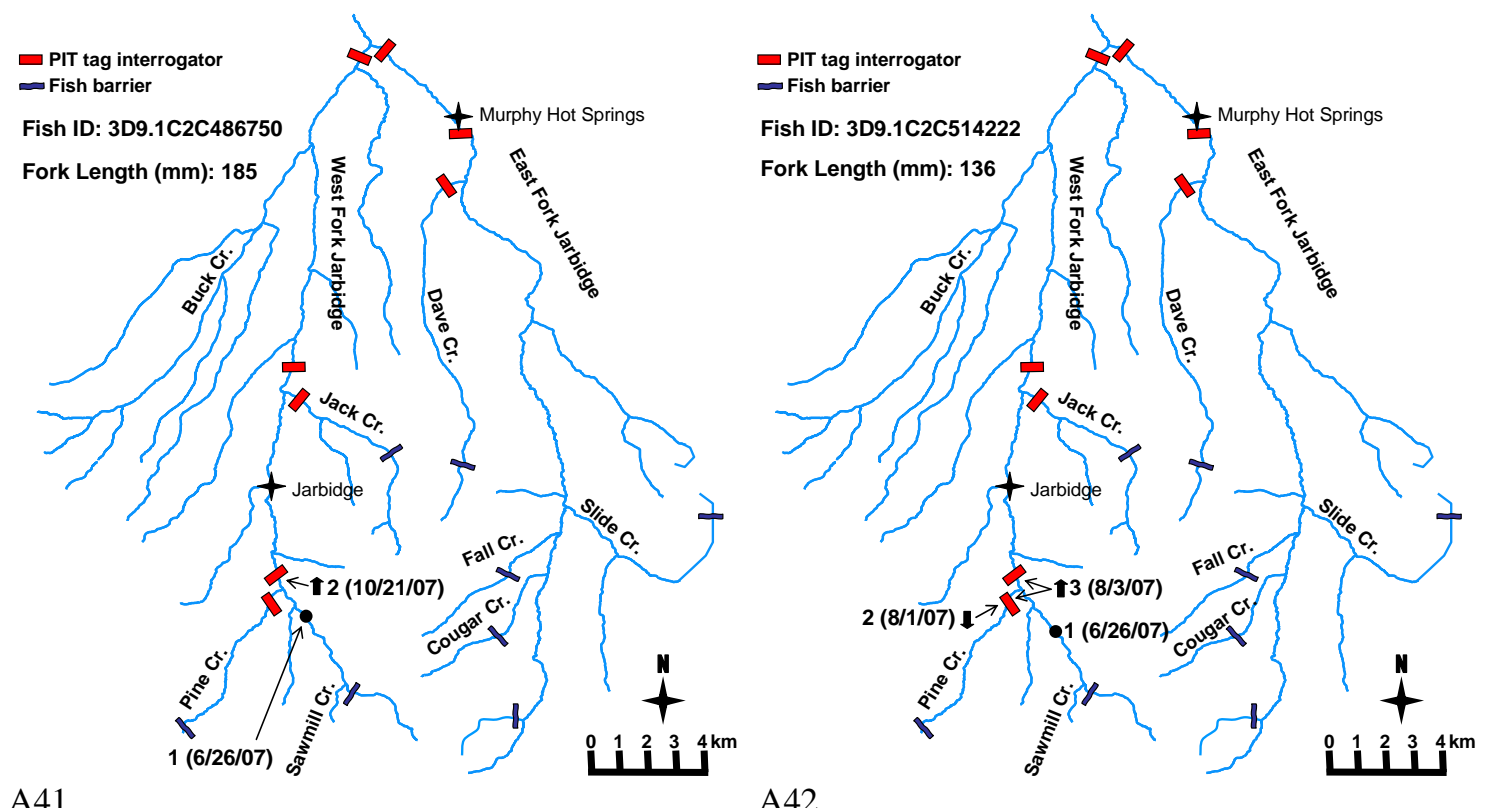

A42
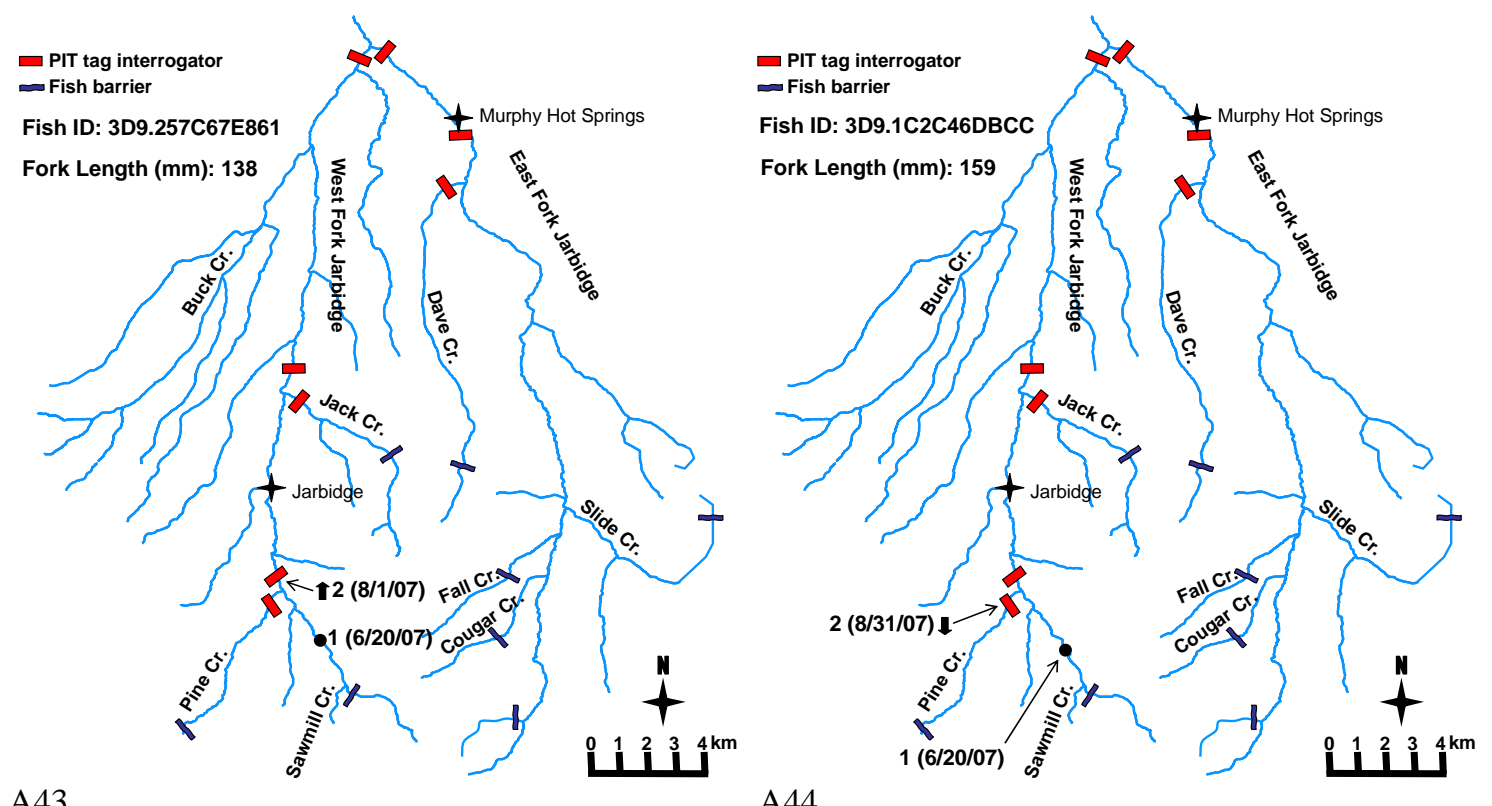

Figures A41 - A44. Movement of PIT-tagged bull trout within the Jarbidge River subbasin in 2006 and 2007. Each map represents a single bull trout and the number next to the symbol represents the order of events ( 1 = tagging, 2 = interrogation or recapture, $3+=$ subsequent interrogation or recapture). See table 8 and figures 28 and 29 for installation dates and summaries of interrogation information. 

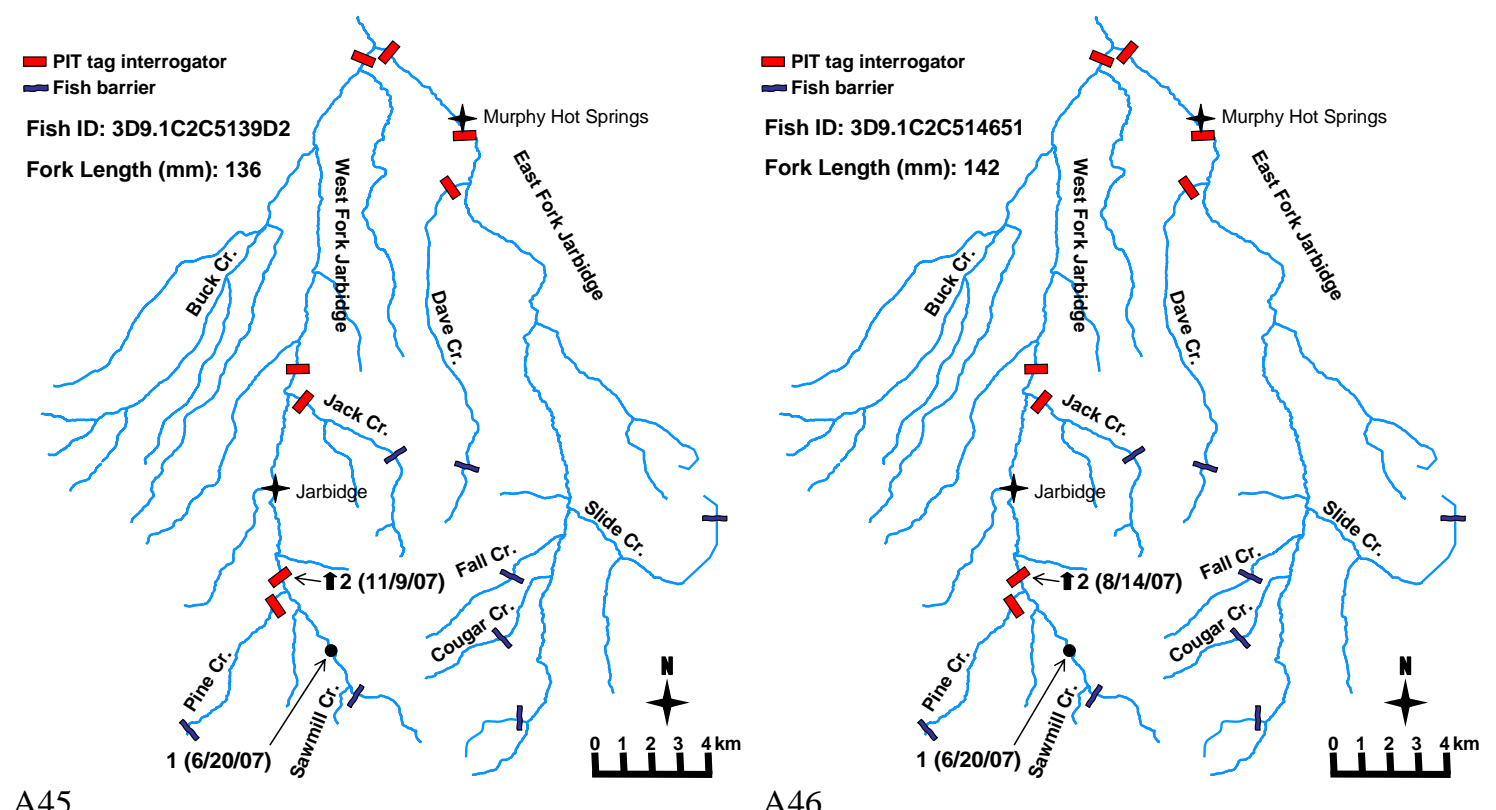

A46
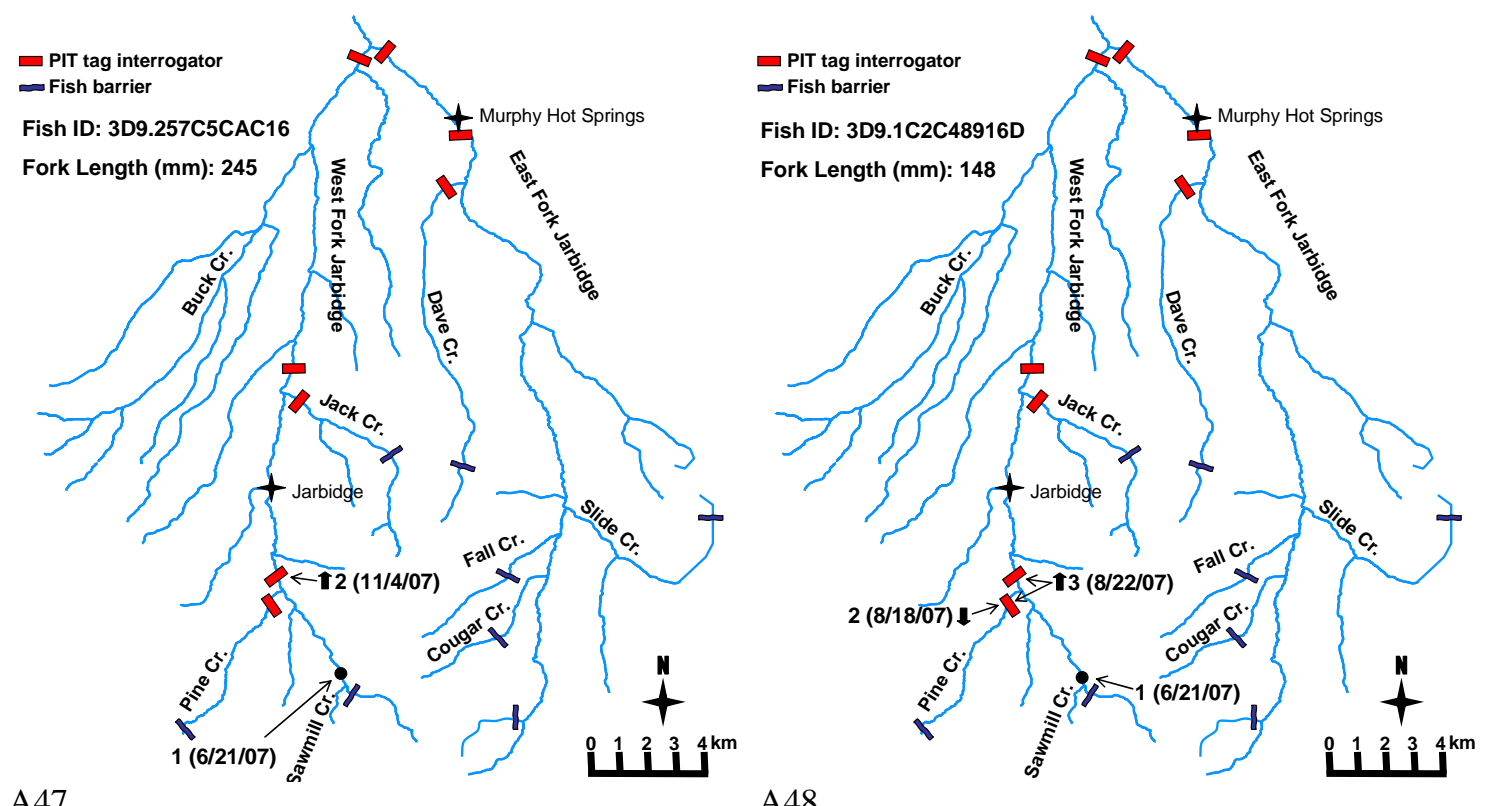

Figures A45 - A48. Movement of PIT-tagged bull trout within the Jarbidge River subbasin in 2006 and 2007. Each map represents a single bull trout and the number next to the symbol represents the order of events ( 1 = tagging, 2 = interrogation or recapture, $3+=$ subsequent interrogation or recapture). See table 8 and figures 28 and 29 for installation dates and summaries of interrogation information. 


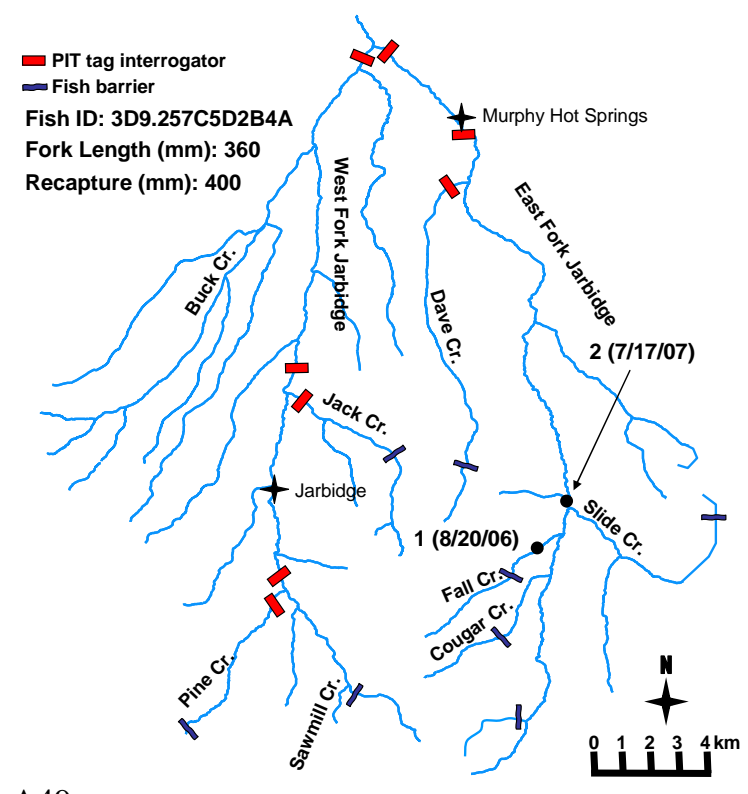

A49

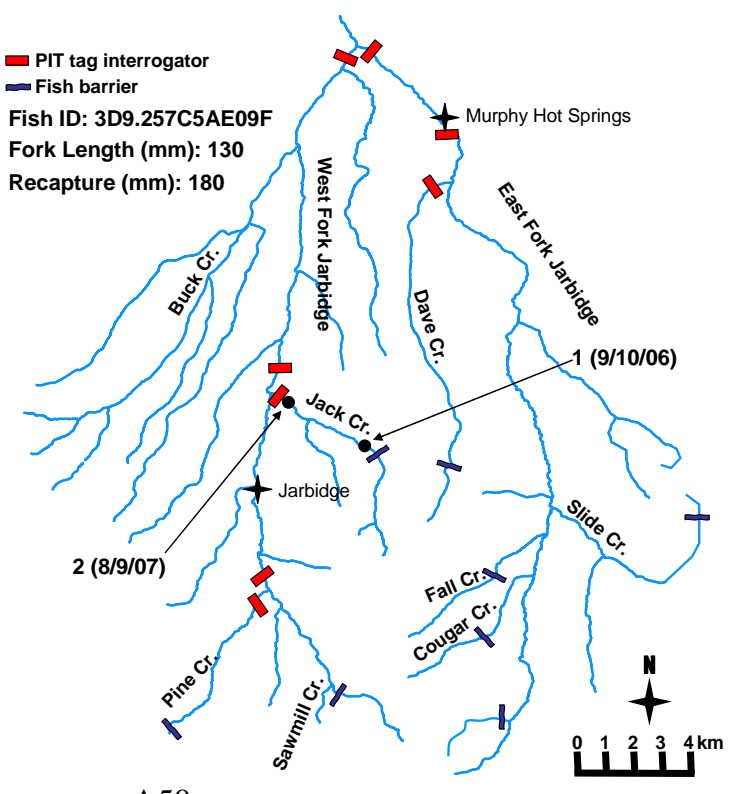

A50

Figures A49 - A50. Movement of PIT-tagged bull trout that were within the Jarbidge River subbasin in 2006 and 2007. Each map represents a single bull trout and the number next to the symbol represents the order of events (1 = tagging, 2 = recapture). 
This page left intentionally blank 
Publishing support provided by the U.S. Geological Survey Publishing Network, Tacoma Publishing Service Center

For more information concerning the research in this report, contact the Director, Western Fisheries Research Center

U.S. Geological Survey, 6505 NE 65th Street

Seattle, Washington 98115

http://wfrc.usgs.gov/ 


\section{寜}

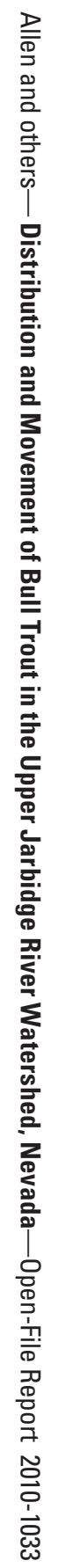

